\title{
WestVirginiaUniversity
}

THE RESEARCH REPOSITORY @ WVU

Graduate Theses, Dissertations, and Problem Reports

2004

\section{Leadership frames of presidents of Master I Higher Education Institutions}

Michael L. Monahan

West Virginia University

Follow this and additional works at: https://researchrepository.wvu.edu/etd

\section{Recommended Citation}

Monahan, Michael L., "Leadership frames of presidents of Master I Higher Education Institutions" (2004). Graduate Theses, Dissertations, and Problem Reports. 2567.

https://researchrepository.wvu.edu/etd/2567

This Dissertation is protected by copyright and/or related rights. It has been brought to you by the The Research Repository @ WVU with permission from the rights-holder(s). You are free to use this Dissertation in any way that is permitted by the copyright and related rights legislation that applies to your use. For other uses you must obtain permission from the rights-holder(s) directly, unless additional rights are indicated by a Creative Commons license in the record and/ or on the work itself. This Dissertation has been accepted for inclusion in WVU Graduate Theses, Dissertations, and Problem Reports collection by an authorized administrator of The Research Repository @ WVU.

For more information, please contact researchrepository@mail.wvu.edu. 
Leadership Frames of Presidents of Master I Higher Education Institutions

\author{
Michael L. Monahan
}

Dissertation submitted to the College of Human Resources and Education at West Virginia University in partial fulfillment of the requirements for the degree of

Doctor of Education

in

Educational Leadership Studies

\author{
Richard Hartnett, Ed. D, Chair \\ Ernest Goeres, Ph. D. \\ Elizabeth Jones, $\mathrm{Ph}$. D. \\ Mary Rittling Ed. D. \\ Richard Walls, Ph. D. \\ Department of Advanced Educational Studies \\ Morgantown, West Virginia \\ 2004
}

Key Words: Bolman and Deal, frames, styles, leadership, Masters I, president, higher education 


\begin{abstract}
Leadership Frames of Presidents of Master I Higher Education Institutions
\end{abstract}

\title{
Michael Lacy Monahan
}

This study examined the leadership styles of presidents at Master's I institutions as defined by the Carnegie Foundation (2001), and called the "Middle Child of Public Higher Education". The entire population of 494 presidents was surveyed and a response rate of 51.4\% was obtained. This study examined the relationships between leadership style and specific demographic variables.

Bolman and Deal devised a four-frame model that included the structural, human resource, political, and symbolic leadership frames. These frames, or windows, allow users to view the world and problems from various perspectives. The structural frame relates to hierarchy and formal rules. The human resource frame focuses on the people in the organization. The political frame views organizations as arenas where participants compete over resources, power, influence, and interests. The symbolic frame focuses on the ceremonies, culture, and myths within an organization. Leaders may predominantly use one style, but are better equipped to handle complex problems by using a multi-frame style.

The Leadership Orientations (Self) 1990 instrument was utilized to reveal that Masters I presidents employed in a statistically significant manner a multi-style approach $(43.7 \%)$, followed by a paired-style (22.4\%), then a single-style (20.9\%), and finally, a no-style (13\%) leadership orientation. Further, it was found that frame utilization was statistically significant. The frames employed in descending order were human resources $(30.7 \%)$, structural $(22.5 \%)$, political $(22.5 \%)$, symbolic $(18.8 \%)$ and no-frame $(5.5 \%)$.

The respondents were predominantly Caucasian (86.6\%) male (76.8), married (79.4\%) in their first presidency $(70.5 \%)$, had been in the position less than ten years $(60.1 \%)$ and were over the age of sixty (47.2\%) Their previous position was chief academic officer $(47.2 \%)$ or president of another institution (26.2\%) Nearly $90 \%$ had earned doctorates, Ph. D. (73.6\%) or Ed. D (16.1\%) with education (31.6\%) as the primary area of academic expertise.

The findings produced no statistically significant differences when comparing leadership style and institutional variables, demographic variables, first time presidents or length of time as president.

Leadership is a complex phenomenon that cannot be explained by this set of variables and may be situational in context. Further study can assist in identifying effective leadership variables. 


\section{ACKNOWLEDGEMENTS}

The pursuit of a doctorate is an activity where the journey is indeed the reward. Through 4 years of personal and professional highs and lows, this life examining and life enriching process occurred. It was a journey I could not have made alone. In light of this fact, I would like to express my appreciation to those who helped me through.

I wish to thank the talented members of my committee:

Dr. Richard Hartnett, my chair and my friend, for his concern and support, rapier wit and encyclopedic knowledge of leadership;

Dr. Elizabeth Jones for taking a leadership position by having the vision to create the cohort program. I am also thankful for her expertise in assessment, curriculum, and APA;

Dr. Ernest Goeres, a fellow business officer, who guided me toward this degree, provided insights and encouragement that greatly assisted toward its completion;

Dr. Mary Rittling, for teaching me that a career in education is indeed a vocation focused on assisting students;

Dr. Richard Walls, for his invaluable statistical help and proof reading expertise; and

Dr. Perry Smith, for graciously agreeing to assist at the $11^{\text {th }}$ hour and teaching me that non-significant is indeed significant.

Thanks to my family and friends who supported me in this adventure, especially my parents, James and Kitty Monahan, my father-in-law, Harold Knotts, and my best friend, Jim Zamagias.

I am especially thankful for the members of the cohort with whom I established a bond of trust and mutual support. 
I would also like to thank the presidents of Masters I institutions who gave of their time to respond to this survey.

Also, I wish to dedicate this dissertation to my wife Terri for her unfailing confidence, support, and love for me. She painstakingly reviewed my work and unselfishly encouraged my time at the library and evenings and weekends at the computer.

Most of all I want to thank God for making it all possible. 


\section{TABLE OF CONTENTS}

Chapter 1. Statement of the Problem

Introduction

The Presidency

Leadership

Colleges and Universities

Statement of the Problem 12

Purpose of Study 12

Significance of the Study 13

Research Questions 14

Conceptual Framework $\quad 14$

Summary 15

$\begin{array}{ll}\text { Chapter 2. Literature Review } & 17\end{array}$

$\begin{array}{ll}\text { Leadership } & 17\end{array}$

$\begin{array}{ll}\text { Trait Theory } & 19\end{array}$

Behavioral Theory 20

Contingency and Situational Theory 22

Cultural and Symbolic Theory 25

Power and Influence Theory 26

Transformational Theory 28

Cognitive Theory $\quad 29$

Bolman and Deal's Four-Frame Model 30

Structural Frame 31

Human Resource Frame $\quad 32$

Political Frame $\quad 35$

Symbolic Frame $\quad 37$

Multi-Frame $\quad 40$

Related Research $\quad 41$

The Presidency 44

Presidential Leadership $\quad 47$

Gender $\quad 52$

Race $\quad 54$

Career Paths $\quad 58$

Presidents of the "Middle Child of Public Higher Education" 62

Operational Definitions $\quad 64$

$\begin{array}{ll}\text { Chapter 3. Method } & 69\end{array}$

Research Design 69

Data Collection and Instrumentation $\quad 70$

Survey Instrument $\quad 71$

Validity and Reliability $\quad 72$

Strengths of the Design 73 
Limitations of the study 73

Assumptions

Site Selection $\quad 74$

Data Analysis $\quad 75$

Timeframe $\quad 81$

Background of the Researcher 81

Chapter 4. Results $\quad 82$

Survey Responses and Demographic Background $\quad 82$

Major Findings $\quad 89$

Research Question 1-Leadership Styles Utilized $\quad 89$

Research Question 2-Leadership Style by Institutional Variables 94

Research Question 3-Leadership Style by Demographic Variables 99

Research Question 4-Leadership Style by Presidency 112

Research Question 5-Leadership Style by Length of Service $\quad 115$

Summary 118

$\begin{array}{ll}\text { Chapter 5. Conclusions and Recommendations } & 120\end{array}$

$\begin{array}{ll}\text { Demographics } & 120\end{array}$

Leadership Styles 124

Leadership Style Studies of Other Higher Education Positions 125

Leadership Frames 126

Frame Studies of Other Higher Education Positions $\quad 126$

Institutional Variables and Leadership Styles 127

Individual Demographic Variables and Leadership Styles 129

First Time and Repeat Presidents 131

Years as a President 131

Recommendations 134

Recommendations for Practice 134

Recommendation for Further Study 136

$\begin{array}{ll}\text { References } & 138\end{array}$

Appendixes

Appendix A: Permission to use survey instrument 162

Appendix B: Survey instrument 164

Appendix C: Cover Letter $\quad 170$

Appendix D: Follow-up letter 171

Appendix E: Institutional Characteristics 172

Appendix F: Size of institutions 173

Appendix G: Location Breakdown for Institutions 174

Appendix H: Community Population Categories 175 


\section{List of Tables}

Table 1. Carnegie Classification of U.S. Higher Educational Institutions $\quad 10$

Table 2. Degrees Earned at Higher Education Institutions 2001

Table 3. Behavior and Situational Theories 25

Table 4. Characteristics of Bolman and Deal Four Frame Model 40

Table 5. Ethnicity Distribution 1986 to 2001 of Masters I \& Total Institutions 55

Table 6. Bolman and Deal survey questions associated with each frame 76

Table 7. Demographic Profile of Presidents 83

Table 8. President Responses by Education and Career Variables 85

Table 9. $\quad$ President Responses by Demographic Variables 86

Table 10. President Responses by Institutional Variables 88

Table 11. Mean and Standard Deviation of Section I 90

Table 12. Leadership Frames Utilized 91

Table 13. Frequency Distribution by Style and Frame 92

Table 14. Leadership Frame Utilized Alone or in Concert 93

Table 15. Distribution Among Enrollment and Location 96

Table 16. Distribution Among Population and Control 98

Table 17. Leadership Styles and Frames by Gender 100

Table 18. Leadership Styles and Frames by Race 102

Table 19. Leadership Styles and Frames by Age 104

Table 20. Leadership Styles and Frames by Marital Status 106

Table 21. Leadership Styles and Frames by Educational Background 108

Table 22. Leadership Styles and Frames by Last Position Held 111

Table 23. Leadership Style and Frames by the Number of Presidencies 114

Table 24. Leadership Styles and Frames by Years as a President 117

Table 25. Comparison of this Study with Corrigan 122

\section{List of Figures}

Figure 1. Halpin's Leadership Behavior Matrix 21

Figure 2. Hersey and Blanchard's Model of Relationship Behavior 23

Figure 3. Blake and Mouton's Managerial Grid 24 


\section{CHAPTER 1}

Introduction

Higher education institutions in the United States have an increasing need for effective presidential leadership to meet numerous challenges ranging from access to fiscal. The major issues include decreasing resources, competition increasing for students, maintaining academic quality, improving access, and utilizing technology to enhance teaching and efficiencies (Levine \& Cureton, 1998, Spanier, 2000, Van Dusen, 2000).

Competition for students is a perennial quest, and it has intensified in recent years, especially in those regions in which numbers of graduating high school students have declined. Concurrently, institutional mission creep and the addition and expansion of programs have encouraged some institutions to imitate those at the top of the funding or prestige pyramid by offering both more degrees and a greater breadth of subject offerings. These adaptations have effectively enlarged colleges' student base, and viability; other institutions, which are under funded or under subscribed face extinction since increased enrollment offsets reduced public higher education funding (Hovey, 1999).

Students expect better service and products at lower costs. They seek depth and breadth of curricular offerings that includes both remedial and challenging courses, student activities and support services, convenience, quality, and value (Levine \& Cureton, 1998). In addition, private, for-profit institutions and customized corporate training programs attract students and their associated revenue that further fuels competition for students.

Resources in higher education have generally been in short supply; however the current state deficits herald significant reductions in funds and subject public institutions to greater oversight and accountability. It is anticipated that higher education spending in 42 states will lag 
non-educational state expenditures (Boyd, 2002). To many, access is now viewed as an entitlement as minorities and under prepared students demand admittance and tailor made services to address their particular needs (Levine \& Cureton, 1998). These costly services place an additional drain on limited funds. Similarly, the needs of the workplace are transforming curriculum as employers demand better skilled and better-educated workers (Pearson \& Young, 2002).

The business community provides some desperately needed financial resources, but these resources come at a price. Business leaders expect placement on governing boards where they can continue to exert control. As physical plants continue to age, the cost, maintenance, and upkeep of facilities require significant capital. It is estimated that the deferred maintenance on college campuses exceeds $\$ 26$ billion (Kaiser \& Davis, 1996). Further, information technology and systems are considered critical by most colleges and universities to enhance access and delivery but with concomitant expenses. Costs are escalating at levels that may cause financial difficulties for those campuses.

Perhaps the most significant challenge is with the faculty. Even though they are the heart and soul of the institution, the policies of tenure, unionization, and the abolition of mandatory retirement increase instructional costs (Ehrenberg, 1997). Further, the concept of shared governance can delay or abort academic and operational initiatives. Since allegiance is often based on the discipline and the department, collegiality has at times been replaced with acrimony (Karol \& Ginsburg, 1980).

It is the task and responsibility of the president to confront these issues, even as these varied demands outrun the universities capacity to respond (Clark, 1998). Green and Levine (1985) contend that opportunity is implicit in adversity (p.ix). However, the right president can 
successfully position institution (Kerr, 1984). The quality that enables presidents to move the institution forward is leadership. Although there are numerous definitions of leadership, leadership is essentially the act of influencing subordinates to accomplish goals or objectives in a particular situation (Hackman \& Johnson, 2000).

The Presidency

The president symbolizes the institution and all that it means to its varied constituents. As the embodiment of the institution, the president conveys many images to the public to reinforce the symbolic and ritual content of the position (Balderson, 1995).

College and university presidents oversee complex organizations that have goals, hierarchical systems, and structures. As policy makers, they make critical decisions that affect the mission and effectiveness of the institution. The central role of the presidency is to ensure the overall and long-term welfare of the institutions of higher education. Vaughan (1989) articulates the major role of the president as:

Creating a campus climate in which students, faculty and their staff can achieve their full potential as learners, professionals, workers and members of the college community. The president sets the tone and pace-establishes the campus moodthat other members of the college community can sense, identify and emulate. (p. 10)

In a word, the president must demonstrate leadership. The presidency is not simply a job or a position; it is a calling, imbued with a sense of moral obligation. Presidents have a moral responsibility to "minister" to society's needs and to offer a critical perspective of its values and behaviors (Fisher, Tack \& Wheeler, 1988). DePree (1989) characterized this perspective as a component of leadership. "The first responsibility of a leader is to define reality. The last is to 
say thank you. In between the two, the leader must become a servant and a debtor" (p.11). In other words, presidents are "managers of meaning" for their organizations.

Researchers and educational leaders reinforce the premise of the value of the presidency and the premise that the person holding the presidency makes a difference. Kaufman (1980) notes, "The president is at the center of a vastly complex and fragile human organization. The president must be effective or the institution will suffer" (p. 14). Similarly, "a college or university cannot rise above the level of the president's leadership" (Chaffee, Whetton, \& Cammeron, 1983, p. 219). It appears that for better or for worse, the fate of an institution is often directly related to its president. Cowley and Williams (1980) assert:

Name a great American college or university and you will find in its history a commanding leader or leaders who held its presidency. Name an institution with a brilliant but now-withered past, however, and you will probably have little difficulty in identifying the weak headman presidents who have blocked its progress. Colleges and universities, focal institutions in the life of the nation, need especially strong leaders. (p. 70)

Likewise, Kerr and Glade (1987) contend:

Nearly all these presidents will have affected their institutions in some significant manner and occasionally in major ways. Some institutions will have survived because of their presidents while a few will have failed, for the same reason. Others will have declined marginally or improved marginally, owing to their presidents efforts. (p. 30)

These observations substantiate the need for presidential leadership. Kerr (1984) asserted, "strengthening presidential leadership is one of the most urgent concerns on the agenda of higher 
education in the United States. It makes a great difference who the presidents are, and what the conditions are that surround their contributions" (p. 102).

Still, the question arises, how do presidents acquire leadership skills? Benezet, Katz and Magnusson (1981) observed that effective presidents are not born and training for the presidency is virtually nonexistent. It is both ironic and surprising that higher education provides training and preparation for almost every other profession, yet does not provide training for its own leaders (Kaufman, 1980). Formerly, the path to the presidency was a six-rung promotional ladder beginning at student, progressing through "professor, department chair, dean, provost or academic vice-president and ending at president" (Cohen \& March, 1974, p.20). Now there are multiple pathways to the presidency as aspiring candidates come from student affairs, advancement, law, business, and the military.

Statistics are available to affirm the changing face of the presidency. In $1986,85 \%$ of presidents came directly out of academic or administrative life on a college campus (Kerr \& Glade, 1986). Kerr and Glade (1986) also reported that seven percent had prior experience in academic life as a faculty member or administrator, and eight percent came from military, business, or other fields. In addition, $80 \%$ came directly from outside the institution where they became president. Ross and Green (2000) found that about $12 \%$ of presidents of private institutions came from outside of higher education compared with only $4 \%$ of presidents of public institutions in 1998. This variance can be partially explained by the religious nature of a number of private institutions that seek their presidents from the ministry.

Although the presidency is critical and respected, its authority and power have been reduced by a variety of sources (Murphy, 1997). Since the mid-1960's, the strength of the presidency has diminished due to federal and state controls, the courts, faculty influence, and 
unionization, greater ambiguity of goals, special interest groups, and shared governance (Kerr, 1984). Changes in the student market, competition, and student-designed programs have also contributed to the loss of influence in academic affairs (Kerr \& Glade, 1987). Since presidents no longer serve as the chief academic officer, their role has become one of chief fundraiser or CEO (Lovett, 2002). Bennis (1991) observed routine work driving out non-routine work, thereby stifling creative planning and fundamental change.

The job of president is often thankless as one's every move and action is under constant scrutiny. The head of the university is at the center of a vastly complex and fragile human organization. Praise may come occasionally, but blame is ever present. The president struggles with internal and external constituencies and is constantly dealing with limited resources. The president is seen as a parental figure:

Like any father, he $[s i c]$ is expected to be home more often, to pay more attention to the "children" to say more kind words to know what his family is doing, to be interested in what they are doing, and to be ready with money when it is needed (Benezet, Katz \& Magnusson, 1981, pp. 17-18).

These increasing demands emerge from constituencies both within and without, and may explain higher turnover rates of presidents. In 1989, the average term as president was fourteen years. The term decreased in 1991 to ten years, and in 1998 it was reduced again to less than seven years. These terms equate to a turnover rate of $7 \%$ in $1989,10 \%$ in 1991 , and $15 \%$ in 2001 (Kerr, 1994, Ross \& Green, 2000, Corrigan, 2002). It was found in 2001 that the average age of presidents was 57.5 years of age (Corrigan, 2002). With the relative maturity of this population, it is reasonable to conclude that by 2010 , a significant percentage of retirements will occur. Further, the Chronicle of Higher Education anticipates $80 \%$ of community college presidents 
will retire in the next decade and replacements may be lost to elementary and secondary schools (Evelyn, 2001).

Consequently, there will be numerous opportunities for candidates desirous of the presidency. But where will aspiring candidates come from? Vaughn predicts presidents moving to another institution will fill only $30 \%$ of community college vacancies. Further, there is declining interest in the position among other college administrators (Evelyn, 2001). Unfortunately, a faster turnover does not necessarily mean that change will come to many institutions. For example, at the nation's community colleges, it is assumed that the next generation of presidents will be a mirror image of the current generation since the majority will come from the academic deanship. There does not seem to be a new breed of leaders to take these institutions in drastically different directions (Vaughan, 1989). If the internal and external constituencies are satisfied with the status quo, the predominant path to the presidency will ensure like results. However, applicants from business and industry, public school superintendents, and vice presidents and deans from 4-year institutions could bring different perspectives and much needed change to these institutions (Vaughan, 1989).

In a 1996 study, public opinion of colleges and universities were "among the most moribund and resistant to change institutions in the United States. Overcoming such opinions and inertia will be one of the major challenges of 21 st century college presidents" (Murphy, 1997, p. 64). Clearly leadership is needed to initiate change and energize both the internal and external constituencies. Kerr (1984) contends, "each campus (and higher education in its entirety) will suffer if that central role is not performed to full effectiveness" (p. 102). 


\section{Leadership}

Presidential leadership can manifest itself in a variety of ways. Bennis (1997) asserted

"To survive in the 21 st century, we're going to need a new generation of leaders -- not managers" (p.63). In order to address these challenges, Karol and Ginsburg (1980) contended that the style of leadership is of primary importance. Benezet, Katz and Magnusson (1981) asserted that presidential leadership is getting faculty and staff to help students make sense of their lives, relieve their anxieties about pursuing an education, develop structures and programs for success in their careers, and cultivate their intellect and sensitivities. Balderson (1995) cites five major functions of university leadership. These functions are the clarification of the mission of the organization and determination of long-range objectives and shorter-range goals, the allocation of the organization's resources to priority uses within the terms of objectives and goals, the selection and evaluation of key personnel, representation of the organization to external constituencies and strategic management, and organizational change.

At a study of 20 institutions identified by Gilley, Fulmer and Reithlingshoefer (1986) as "on the move," presidential leadership was found to be a strong force in every one of the institutions. The most important personal presidential quality observed was visionary intelligence. The presidents at those institutions were both creative and inquisitive as they had specific plans for the future of their institutions. They were also persistent in searching for ideas

to help the institution move forward. Finally it was concluded that in higher education, views of effective leadership vary according to constituencies, levels of analysis, and institutional types.

Different types of leaders utilize different styles of leadership. Kerr and Glade (1996) outlined four types of leaders: pathbreaking leaders, managerial leaders, survivors, and scapegoats. Pathbreaking leaders take charge in moving into new territory. They take deliberate 
efforts to create new endeavors or to improve substantially on the performance and direction of existing endeavors. Managerial leaders are more concerned with perfecting what is currently being done and what needs to be done in particular situations. Survivors do not rock the boat, articulate visions, or seek efficiencies. They are manipulators who play politics to keep their position. Scapegoats either blame their predecessors, environment or subordinates for failure to reach objectives or they seek martyrdom for themselves.

Leadership defies a simple explanation as many definitions and styles of leadership exist. Bensimon, Neumann, and Birnbaum (1989) identified six types of leadership theories. They are: trait, power and influence, behavioral, contingency, cultural and symbolic, and cognitive theories. Trait theories attempt to identify specific personal characteristics that contribute to a person's ability to assume and successfully function in positions of leadership. Power and influence theories consider leadership in terms of the source and the amount of power available to leaders, and the way that leaders exercise that power over followers. Behavior theories examine the leaders patterns of activity, roles and categories of behavior. Contingency theories emphasize the importance of situational factors. Cultural and symbolic theories study the influence of leaders in maintaining or reinterpreting the system of shared beliefs and values that give meaning to organizational life. Finally, cognitive theories depict leadership is a social attribution that permits people to make sense of an equivocal, fluid, and complex world.

\section{Colleges and Universities}

Institutions of higher education are literally in a class by themselves. They are complex organizations with diversity in their structure, governance, and mission. Challenges and opportunities abound, and solutions to problems are rarely simplistic. There are 3,913 institutions 
of higher education in the United States; $41.7 \%$ are publicly controlled, $42.7 \%$ are privately controlled, and $15.6 \%$ are operated as for profit institutions (Carnegie Foundation, 2002). Table 1 depicts the number of institutions comprising each classification.

Table 1

Carnegie Classification of U.S. Higher Educational Institutions*

\begin{tabular}{|c|c|c|c|}
\hline Classification & Number & Subtotals & $\%$ \\
\hline Doctoral/Research Universities & 261 & & $6.7 \%$ \\
\hline Doctoral/Research Universities_Extensive & & 151 & \\
\hline Doctoral/Research Universities_-Intensive & & 110 & \\
\hline Master's Colleges and Universities & 611 & & $15.6 \%$ \\
\hline Master’s Colleges and Universities I & & 496 & \\
\hline Master's Colleges and Universities II & & 115 & \\
\hline Baccalaureate Colleges & 606 & & $15.5 \%$ \\
\hline Baccalaureate Colleges_Liberal Arts & & 228 & \\
\hline Baccalaureate Colleges_-General & & 321 & \\
\hline Baccalaureate/Associate’s Colleges & & 57 & \\
\hline Associate's Colleges & 1,669 & & $42.7 \%$ \\
\hline Specialized Institutions & 766 & & $19.6 \%$ \\
\hline Total & 3,913 & & $100.0 \%$ \\
\hline
\end{tabular}

* Adapted from Carnegie Foundation, 2001

Many presidential studies have been conducted on the CEO's of community colleges, private colleges, and major universities. However, there is a paucity of research conducted on Masters I institutions; they are an overlooked segment of the college population. These institutions annually award more than 40 Masters Degrees in three or more disciplines (Carnegie Foundation, 2001). 
There are 494 Masters I institutions. They account for only one-eighth of the total system, yet they produce one-fourth of the total degrees. Masters I institutions are almost equally comprised of public controlled and privately controlled institutions. Only one for-profit institution exists (Carnegie Foundation, 2001). These institutions produce a third of the bachelors and masters degrees earned nationwide. Jeffrey Selingo (2000), writing in Chronicle of Higher Education, dubbed these institutions as the "Middle Child of Public Higher Education." They are situated between the major universities and the community colleges, and offer associates, bachelors, masters, and selected doctoral degrees. Although they are classified as Masters I, over $70 \%$ of the degrees they award are bachelors (Carnegie Foundation, 2001).

Table 2 illustrates the percentage of degrees earned by students at all the institutions.

Table 2

Degrees Earned at Higher Education Institutions 2001*

\begin{tabular}{|c|c|c|c|c|c|}
\hline Degree & $\begin{array}{c}\text { Total number } \\
\text { Earned at All } \\
\text { Institutions } \\
\end{array}$ & $\begin{array}{l}\text { Percentage } \\
\text { of Degrees } \\
\end{array}$ & $\begin{array}{c}\text { Number Earned } \\
\text { at } \\
\text { Masters I } \\
\text { Institutions } \\
\end{array}$ & Percentage & $\begin{array}{c}\text { Masters I } \\
\text { Percentage } \\
\text { of Degrees } \\
\end{array}$ \\
\hline Associates & 578,865 & $23.9 \%$ & 16,532 & $2.8 \%$ & $2.9 \%$ \\
\hline Bachelors & $1,244,171$ & $51.4 \%$ & 404,970 & $68.9 \%$ & $32.5 \%$ \\
\hline Masters & 473,000 & $19.5 \%$ & 156,791 & $26.7 \%$ & $33.1 \%$ \\
\hline Doctoral & 79,707 & $3.3 \%$ & 998 & $.2 \%$ & $1.3 \%$ \\
\hline 1st Professional & 44,904 & $1.9 \%$ & 8,307 & $1.4 \%$ & $18.5 \%$ \\
\hline Total & $2,420,647$ & $100.0 \%$ & 587,598 & $100.0 \%$ & $24.3 \%$ \\
\hline
\end{tabular}

* Data obtain from the National Center for Education Statistics

The Masters I classification consists of institutions that award at least 40 master's degrees across at least three disciplines. However, there are a number of institutions that far exceed these 
minimal criterions. For example, the average institution awarded 285 master's degrees in 19971998 across twelve disciplines. However, 3,667 master's degrees in 28 fields were produced at the largest institution, and another institution, though smaller in terms of degree production, provided 1,274 degrees across 57 disciplines (Carnegie Foundation, 2001). Thus, central tendencies for this sector may be especially misleading.

Many of these institutions started as normal schools that focused on teacher training, and then became teachers colleges at the beginning of the $20^{\text {th }}$ century. In the pursuit of prestige and research dollars, a few masters and doctoral programs were instituted. Unfortunately in the process of trying to enhance their identity, they have, in many cases, lost their uniqueness, and are as a consequence being squeezed at both the upper, and lower ends of the college hierarchy. Therefore, the survival of these institutions is dependent on redefining their mission and having the leadership to make decisions to bring differentiation to these institutions (Selingo, 2000).

\section{Statement of the Problem}

This study will identify the leadership styles utilized by Masters I presidents and determine if there are any significant differences in individual or institutional characteristics.

\section{Purpose of the Study}

The purpose of this study is to (a) identify the leadership frame(s) utilized by presidents of Masters I institutions, (b) examine whether the leadership styles are influenced by institutional variables or (c) other demographic characteristics. This study is important for several reasons. It will provide insight into the leadership styles of presidents. It will examine significant differences among gender, race, control, size, background, education, first or multiple presidencies of Masters I institutions, and leadership styles. This study will add to the body of knowledge about the presidency, provide information that could be used in training for aspiring 
presidents, assist institutions in their selection criteria for new presidents, and highlight the Masters I institution population that is often neglected in research.

Significance of the Study

Higher educational institutions are complex organizations that are confronted internally and externally by personnel and environmental factors. Leadership is desperately needed to address these challenges. Research has been conducted on the leadership of presidents utilizing the four-frame model but no study has exclusively studied Masters I institutions and sought to identify relationships by institutional and demographic characteristics. This study is significant for the following reasons:

1. The findings will contribute to a better understanding of the leadership style of Masters I presidents.

2. The findings will enable Masters I presidents and others to reflect and rethink the way they view situations.

3. As the length of the term of presidents decreases and less prospective presidents come from academia, exploration of leadership behaviors could assist in identifying attributes which could lead to success as president.

4. The findings will allow aspiring Masters I presidential candidates to examine their own performance and behaviors.

5. The results will illuminate the various leadership styles of Masters I presidents in a novel manner and examine differences between leadership, institutional, and demographic variables.

6. The results will have implications for graduate programs in educational leadership that prepare students for administrative positions in higher education. 
7. Students training for careers in higher education can begin reframing problems and nurturing this skill throughout their careers.

\section{Research Questions}

1. Do presidents of Masters I institutions predominantly utilize, no-style, a singlestyle of leadership, a paired-style of leadership, or multi-style of leadership?

2. Is there a statistically significant difference in leadership style that is affected by institutional variables such as size of institution, geographic location, community population, and type of control (Appendices F, G, H)?

3. Is there a statistically significant difference in leadership style that is affected by demographic characteristics such as gender, race, age, marital status, educational background, and last position held?

4. Is there a statistically significant difference in leadership style of individuals who are first-time presidents and repeat presidents?

5. Is there a statistically significant difference in leadership style of individuals who have less than one year of experience as a president, between one and five years of experience as a president, between six and ten years of experience as a president, between eleven and fifteen years of experience as a president, and more than fifteen years of experience as a president?

\section{Conceptual Framework}

This study will utilize the four-frame leadership model devised by Bolman and Deal (1990). Frames open different windows of organizational reality and give leaders multiple strategies for addressing challenges. These four dimensions are (a) the structural frame, (b) the human resource frame, (c) the political frame, and (d) the symbolic frame. The authors devised 
these frames as an extension of previous theories and research. The structural frame focuses on formal rules, hierarchy, and the goals of the organization. The human resource frame focuses on the needs of the people within the organization. The political frame views organizations as arenas where participants compete over resources, power, influence, and interests. Finally, the symbolic frame focuses on the intangible aspects of the organization such as culture, myths, ceremony, and rituals. Leaders tend to favor certain frameworks over others but a single framework style may limit their ability to successful address situations. Therefore, in addition to the single frame, leaders may utilize a paired (using two frames) or multi-frame (utilizing three or more frames) strategy. This reframing will enable the leader to view, analyze, and develop solutions from one or more different perspectives. Bolman and Deal (1997) contend that effective leaders are multi-framed, that is they utilize at least three of the four frames. This multiframe leadership provides the leader with more potential opportunities and solutions.

\section{Summary}

Higher education institutions need strong presidential leadership to survive the challenges of the $21^{\text {st }}$ century. The type of leadership utilized by presidents may be an important factor in determining how institutions weather the storms of change. Presidential turnover will provide numerous opportunities for new leaders to man the helm of higher education institutions. An often-neglected segment of research in higher education institutions is the Carnegie Classification Masters I institutions. These institutions will experience many changes over the next decade, as their presidents may have to take bold and controversial moves to safeguard their future. These presidents can benefit from learning how to view and solve problems from multiple perspectives. The four-frame model developed by Bolman and Deal will be used to 
identify which frames the presidents utilize. Further, this study will seek to identify if there are any statistically significant demographic variables that influence the type of leadership used.

Chapter Two will examine the literature in terms of leadership, presidents, institutions, and demographic variables and cite relevant recent research appropriate to this study. 


\section{CHAPTER 2 \\ Review of the Literature \\ Leadership}

This study explores the relationships between the leadership frames of presidents of Masters I institutions and selected demographic variables. This review will begin with a study of the independent variable, leadership, then presidents and their personal and organizational characteristics, and finally the institutions of higher education.

First, leadership is distinguishable from management, even though there is some overlap between the two behaviors (Burns, 1978; Bennis, 1997; Weathersby, 1999; Kumle \& Kelly, 2000). Leadership embodies trust and vision, while management deals with controlling and allocating scarce resources (Weathersby, 1999; Kumle \& Kelly, 2000).

Bennis (1997) articulated the differences between leaders and managers as follows:

The leader conquers the context, the managers' surrender to it

The manager administers; the leader innovates

The manager is a copy; the leader is an original

The manager maintains; the leader develops

The manager relies on control; the leader inspires trust

The manager has a short-range view; the leader has a long-range perspective

The manager asks how and when; the leader asks what and why

The manager has his eye on the bottom line; the leader has his eye on the horizon

The manager accepts the status quo; the leader challenges it

The manager does things right; the leader does the right thing. (p. 63) 
It appears that forward thinking and initiative for positive change are the two most powerful characteristics of leaders. "More than anything, the difference between a leader and a manager rests on the status quo: Managers are willing to live with it, and leaders are not" (Bennis, 1997, p. 17).

Bennis and Nannus (1985) confirmed this assertion when they stated:

There is still no agreement on how leadership can be defined, measured, assessed or linked to outcomes and no clear and unequivocal understanding exists as to what distinguishes leaders from nonleaders, and perhaps more important, what distinguishes effective leaders from ineffective leaders. (p. 4)

There are, however, three assumptions that are shared by a number of authors concerning leadership: leadership is a group phenomenon, involving the interaction of two or more persons; the leader is a group member who can be distinguished from other group members (followers or subordinates) and leadership is a process whereby leaders exert intentional influence over followers (Yukl, 1994).

In summary, leadership does not happen in a vacuum since other people (followers) are needed. It is apparent who the leader is, and leaders use various types of power to influence followers to do something that they would or could not have done otherwise.

According to Benezet, Katz and Magnusson (1981):

The job of leadership, above all, is to enlist faculty and other staff members in the task of helping students become aware of their deeper motivations for making sense of their lives and their world, to relieve their anxieties about pursuing an educational course in college, and to develop the structures and programs that will allow them simultaneously to prepare for the marketplace and to cultivate their intellect and sensitivities (p. 85). 
Balderson (1995) identified five major functions of university leadership: the clarification of the mission of the organization, the determination of long-range objectives and shorter-range goals, the allocation of the organization's resources to priority uses within the terms of objectives and goals, the selection and evaluation of key personnel, representation of the organization to external constituencies, and strategic management and organizational change. Hersey and Blanchard (1982) asserted, "there is no normative (best) style of leadership; that successful leaders are those who can adapt their leader behavior to meet the needs of the followers and the particular situation" (p. 148). However, the situation remains the determining factor in the effectiveness of the particular traits. As a synthesis of the major conceptual studies, an operational definition of leadership can be formulated. Leadership is the act of influencing subordinates to accomplish goals or objectives in a particular situation.

Leadership is a complicated phenomenon with a multitude of definitions and interpretations. In order to bind this concept, the work Bensimon, Neumann, and Birnbaum (1989) was studied. They identified six types of leadership: trait, power and influence, behavioral, contingency, cultural and symbolic, and cognitive theories.

\section{Trait Theory}

Trait theories, as the name implies, attempts to identify specific personal characteristics that equate to leadership. Proponents of this early theory believe that that leaders are born not made. Individuals who posses certain characteristics or traits were predisposed to leadership (Bensimon, et al, 1989; Bass, 1991; Bryman, 1996; Yukl, 1994). These traits included education, race, income, age, height, weight, knowledge, creativity, and mathematical ability. Some traits are considered to be innate and other traits can be developed. Stodgill (1948) examined 124 trait studies from 1904-1947 and concluded that the impact of traits on leadership ability varies from 
situation to situation. Since the trait approach produced inconclusive results, the pure trait approach to leadership was abandoned (Hoy and Miskel, 1996).

Industrial psychologists continued trait research but focused on the relationship between leader effectiveness and leader personality traits rather than comparing leaders and nonleaders (Hoy and Miskel, 1996). In 1970, Stodgill (1981) reviewed another 163 trait studies and concluded that the following traits were characteristic of a leader: vigor and persistence in pursuit of goals, drive for responsibility and task completion, initiative, self-confidence, willingness to accept consequences and tolerate frustration, and the ability to influence others' behavior. Katz (1974) designed typologies of the technical, human, and conceptual managerial skills, however Rosen, Billings, Robber and Turney (1976) found that technical expertise was a stronger predictor of management effectiveness.

Despite the popularity of the trait theory, Stodgill and others concluded that individual traits are not predictive of leader behavior since they are dependent on the situation for their applicability.

\section{Behavioral Theory}

Yukl (1994) studied behavior to determine leader effectiveness. Andrew Halpin at Ohio State University explored the ramifications of this theory. Halpin (1957) examined managerial behavior toward subordinates devised the Leadership Behavior Description Questionnaire (LBDQ) to identify two dimensions of leadership: consideration and initiating structure. Consideration is concerned with the leader's behavior toward developing mutual trust, two-way communication, respect for subordinates ideas, and concern for their feelings. Initiating structure, also known as task orientation, is concerned with leader behavior oriented toward structuring subordinate activities for the purpose of goal attainment. 
Figure 1 illustrates the matrix for the four possible outcome combinations of high and low consideration and initiating structure. For example, employee satisfaction with the leader depends on degree of consideration shown by the leader. Leader consideration affects employee satisfaction more when jobs are unpleasant and stressful than when they are pleasant and relaxed.

A leader high in consideration can exercise more initiating structure without a decline in employee satisfaction. Consideration given in response to good performance will increase the likelihood of improved future performance. Initiating structure that adds to role clarity will increase satisfaction; however it will decrease employee satisfaction when structure is already adequate. Initiating structure will increase performance when a task is unclear and will not affect performance when a task is clear (Yukl, 1994).

Figure 1. Halpin's Leadership Behavior Matrix *

\begin{tabular}{|c|c|c|}
\hline \multirow[t]{3}{*}{ High Consideration } & High Consideration & High Consideration \\
\hline & Low Structure & High Structure \\
\hline & Low Consideration & Low Consideration \\
\hline \multirow[t]{3}{*}{ Low Consideration } & Low Structure & High Structure \\
\hline & Low & High \\
\hline & Initiating Structure & Initiating Structure \\
\hline
\end{tabular}

*Adapted from Hackman and Johnson, 2000

Researchers at Michigan State University examined "identification of relationships among leader behavior, group processes, and measures of group performance" as three factors that differentiated between effective and ineffective managers that led to the finding of taskoriented behaviors, relationship-oriented behaviors, and participative leadership (Yukl, 1994). 
Both studies revealed that the situation affected the leaders behavior even though the exact behavior for certain situations remained unidentified (Yukl, 1994). (Bass and Avolio, 1994) found leaders who are consistent, utilize power wisely, share risks, and have high standards of conduct epitomize this theory.

\section{Contingency and Situational Leadership Theory}

Contingency and situational leadership focuses on the external situation as a determinate of the leadership style. Correlating and compiling the situation with an effective behavior can create operating procedures that could be used when needed (Northouse, 2001).

This approach focused on the characteristics of the situation that might affect the development of leadership. This theory also suggests traits required of a leader differ according to varying situations. Some of the variables that determine leadership effectiveness are the personalities involved, the performance requirements of the job, and the degree of interpersonal contact, time and environmental constraints, and the nature of the organization.

Hersey and Blanchard's Theory of Situational Leadership (1982) is comprised of three main factors: the amount of task behavior the leader uses, the amount of relationship behavior the leader uses, and the level of task-relevant maturity followers exhibit. Maturity is a function of the desire for achievement, the willingness to accept responsibility, and the education, experience, and skills relevant to the task. The maturity level of the followers dictates the leader's style. The theory can be graphed into four quadrants depicting the combinations of high and low leadership and task behavior. Figure 2 illustrates the quadrants and the relationship between followers' maturity and leadership style. 
Figure 2. Hersey and Blanchard Model of Relationship Behavior*

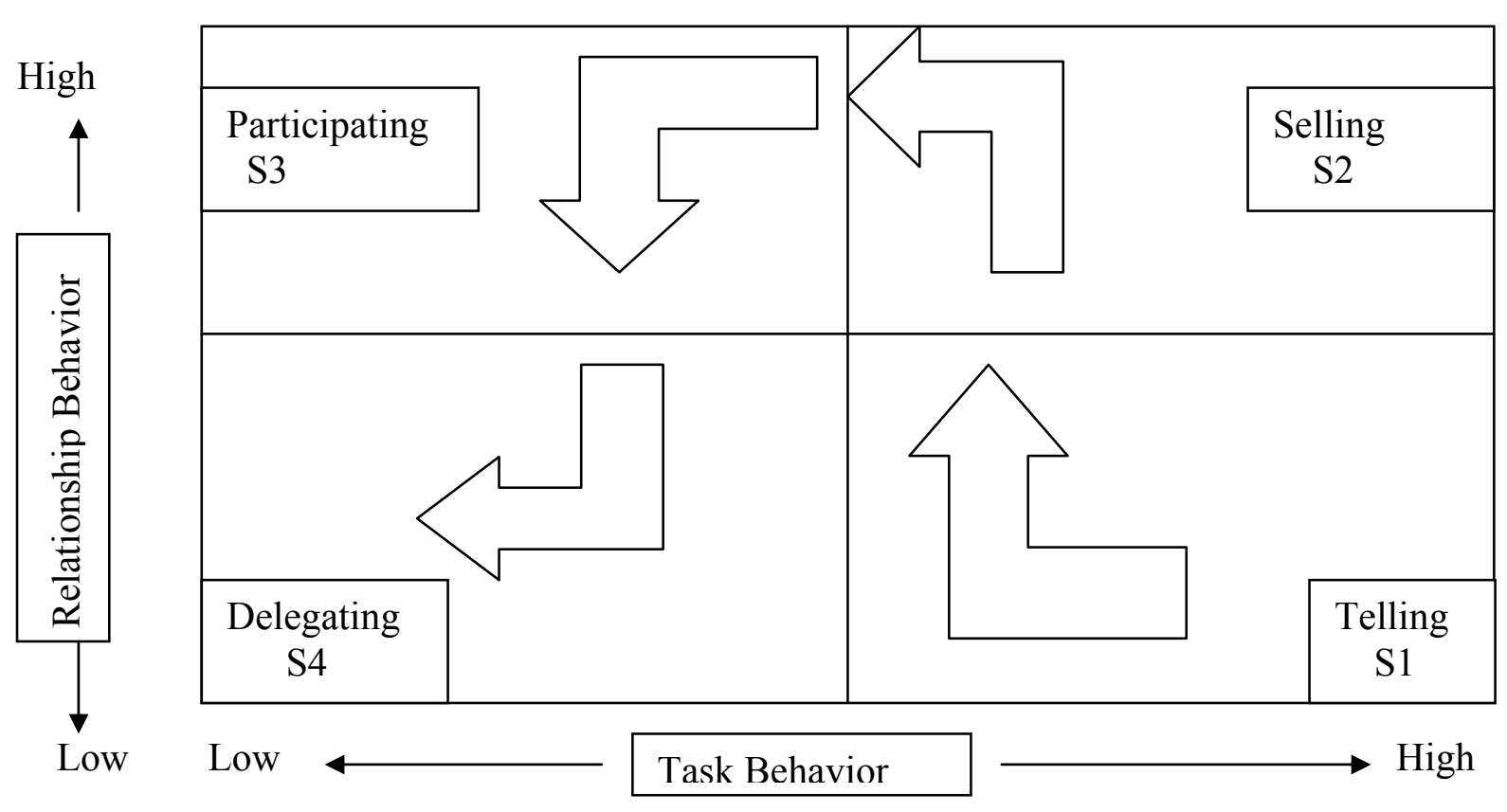

Follower Readiness

\begin{tabular}{cccc} 
High & Moderate & Moderate & Low \\
R4 & R3 & R2 & R1 \\
\hline Able and & Able but & Unable but & Unable and \\
willing or & unwilling & willing or & unwilling or \\
confident & or insecure & confident & insecure \\
\hline
\end{tabular}

*Adapted from Hackman and Johnson, 2000

Finally, Blake and Mouton (1976) designed a framework in which a leader's concern for task was compared with the concern for relationship. Five dimensions were found and are represented in Figure 3. Low task/Low relationships are referred to as impoverished management. Low task/high relationships refer to country club management. Medium task and medium relationships refer to middle of the road management where an adequate amount of task is accomplished with morale at a satisfactory level. High task/Low relationship refers to 
authoritarian management and High task/High relationships refer to team management. Team management is the superior style of leadership as it balances the concern for task and the concern for relationships, thereby maximizing both.

Figure 3. $\quad$ Blake and Mouton Managerial Grid*

Concern for

Relationships

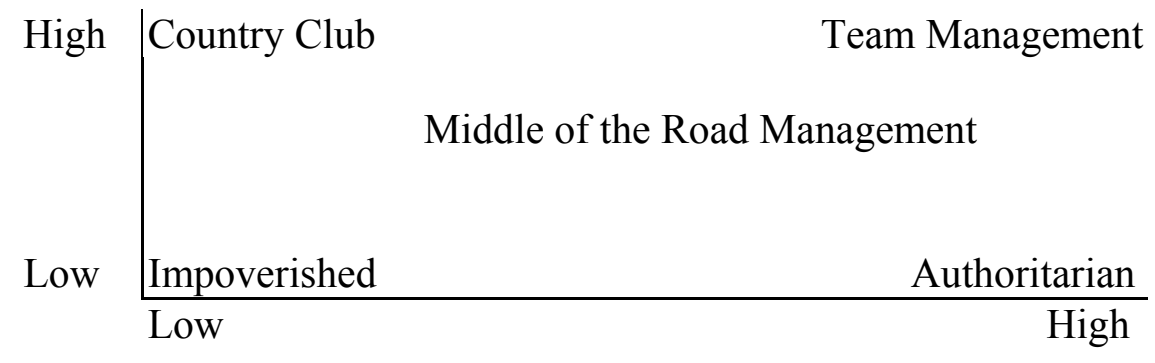

Concern for Tasks

*Adapted from Hackman and Johnson, 2000

Effective leaders, according to this theory, must have the skill to determine the needs of their followers and the ability to adjust their leadership style to address those needs and the situation. The followers can then master new skills and gain confidence in their work (Northouse, 2001; Yukl, 1994). Situational leadership has many advocates in the corporate environment and is seen as an effective model for training aspiring leaders (Hersey \& Blanchard, 1982).

Although these situational models provide useful contingencies and better insights into the processes required for leadership, the complexity of the models raises additional issues. Dill (1987) questioned why the situational model so consistently focuses on relationships with subordinates if relating to one's subordinates is only a part of the activity of managerial leadership. Further, the theory does not offer a list of all other situational variables that can be measured in a single survey instrument; therefore multiple instruments would be needed. Like behavior theories, the research results of contingency theories were found to be inconsistent 
(Bryman, 1996). In the early 1980s, this approach lost popularity since it was not any more comprehensive in measuring leadership than the trait theory. Table 3 summarizes the behavioral and situational theories.

Table 3

Behavior/Situational Theory*

\begin{tabular}{ccc}
\hline Research Site & Task & Human Relationships \\
\hline Ohio State University & Initiating Structure & Consideration \\
Michigan State University & Production Oriented & Employee Oriented \\
Managerial Grid & Concern for Production & Concern for Relationships \\
Fiedler & Task Oriented & Relationship Oriented \\
Hersey/Blanchard & Task Behavior & Relationship Behavior \\
\hline
\end{tabular}

*Adapted from Hackman and Johnson, 2000

Cultural and Symbolic Theory

Cultural and symbolic theory centers on the leader's ability to devise and manipulate symbols to aid in the creation of reality and to reach identified goals (Hackman \& Johnson, 2000). Organizations are described as tribes, theaters, carnivals, or cultures propelled more by rituals, ceremonies, stories, heroes, and myths than by rules, policies, and managerial authority (Bolman \& Deal, 1997). Bensimon, et al, (1989) believed that cultural and symbolic theories were insightful in understanding the internal dynamics of organizations experiencing financial crisis. According to Tierney (1989), there are six categories of symbols that leaders may use to exhibit their leadership roles: metaphorical, physical, communicative, structural, personification, and ideational. They "reside in a wide variety of discursive and non-discursive message units: an act, event, language, dress, structural roles, ceremonies, or even spatial positions in an organization" (In Peterson et al, 1991, p. 433). In the context of leadership, symbols are more 
than just "objectifications of meaning" (Turley, 2002, p. 51). Hence, leaders must know how to use symbols to "create and interpret their organizational reality" (In Peterson et al, 1991, p. 433).

The cultural and symbolic theories made important contributions to the understanding of leadership, emphasizing the subjective nature of reality. However, Tierney (1989) cautions that an effective leader should use the symbol that is consistent with the institution's culture.

Bensimon et al. (1989) stress that a cultural or symbolic approach alone is not effective. However, when used in conjunction with other leadership strategies, effectiveness can result. Power and Influence Theory

Power is a reality of organizational and personal life and is used to overcome the resistance of others. Leadership uses power to persuade others to do things that they would not otherwise do. Hackman and Johnson (2000) contend, "power can exist without leadership, but leadership cannot exist without power" (p. 131). This belief corresponds to Komives, Lucas, and McMahon (1998) who assume "leadership is an influence or social exchange process" (p. 37). Therefore, leadership by its nature is not a single incident. Power is used to influence others to achieve group goals (Hackman \& Johnson, 2000).

French and Raven (1968) outlined five types of power: legitimate, reward, coercive, expert, and referent power. Leaders can influence followers through their positions due to the legitimacy accorded to them within the confines of their position. Influencing others via the provision of rewards is reward power. Conversely, the use of punishment for compliance constitutes coercive power. Expert power is revealed through the leader's knowledge and expertise, and referent power is linked to the leader's personality and the extent of followers' identification with the leader. 
Fisher (1984) studied power and found referent to be the most effective, followed by expert power, then legitimate power, reward power, and finally coercive power. He found legitimate power an effective and necessary form of presidential power since leaders who present themselves as being legitimate tend, in fact, to be more powerful. They are generally better liked and their attempts to sway are more accepted. Reward power does not change attitudes permanently and may cause users to become exploited. Expert power provides an advantage when dealing with issues. Fisher found leaders who combine referent with expert and legitimate power, with measured amounts of reward power, and little or no coercive power, achieved maximum effectiveness. A leader who already has a measure of power can sometimes dramatically increase his or her authority by recognizing and responding to the fact that people are attracted to persons of power. Members of a community expect their leaders to try and persuade them. However, the way in which presidents interact with subordinates demonstrates a personal sense of identification with people that can be more influential than the actual distribution of rewards and privileges (Fisher, 1984).

The very organization of a college or university invites conflict. However, resolved conflict can inspire healthy competition and produce impressive results. Conflict also allows the president to redefine the limits of power, or delegate authority elevating the presidential office (Fisher, 1984). Benezet, Katz, and Magnusson (1981) contend that regardless of the size of the institution, the same type of problems manifest themselves. These problems included dealing with limited resources, developing strategies for winning support from the various constituencies, considering requests, settling disagreements, and responding to malcontents or “ambivalents." Power is a tool that assists presidents in addressing various problems and constituencies (Fisher, 1984). 
The power and influence theories are useful since they recognize the role of the followers and their relationship to leadership. The perspective of the power and influence theories also contributed to the emergence of transformational theories. However, the power and influence theories haven't considered the effects of context on leadership, and also have ignored the process by which influence is managed.

\section{Transformational Theory}

Transactional leadership concentrates on the exchange of both rewards and punishments for desired outcomes, seeks to maintain the status quo, initiates punishment to improve performance, and provides rewards for effort. However, this style does little to inspire ownership or heightened performance (Hackman \& Johnson, 2000).

Conversely, James McGregor Burns (1978) asserted that leadership more than a set of behaviors. Moreover, it is a process whereby "leaders and followers raise one another to higher levels of morality and motivation" (p. 20). Burns associated the roles of leaders and followers and determined that leadership and wielding power was inseparable from the needs of followers (Northouse, 2001).

There are five components to transformational leadership. First, leadership does not occur in a vacuum as it occurs with two or more participants. Second, leadership involves opposition and exists under conditions of conflict and competition for followers. Third, the motives and needs of the followers change to affect the group. Fourth, leadership is driven by the values and vision that is shared between leader and followers. Finally, transformational leadership raises the values of both the leader and the followers (Burns, 1978). 
Hoy and Miskel (1996) contend that transformation leadership can transform an organization by increasing performance, fostering dedication, and altering personal values and beliefs. Followers share the leaders vision, and are both empowered and self-motivated.

Surpassing individual needs by seeking a common purpose and striving for selfactualization are by-products of transformational leadership (Bass, 1991; Bennis \& Nanus, 1985). The resultant synergy between leaders and followers transforms both and leads to higher levels of motivation and morality (Northouse, 2001). Transformational theory of leadership advocates the appointment of a strong charismatic president to lead and transform the university through the power of his or her own vision for the future (Wheeler \& Tack, 1989).

Gardner (1990) highlighted nine tasks critical to leadership that included components of both transformational and transactional leadership. These tasks are envisioning goals, affirming values, motivating, managing, achieving workable unity, explaining, serving as a symbol, representing the group, and renewing.

Cognitive Theory

Cognitive theories are closely related to symbolic theories. Bensimon et al. (1989) explains "Leadership is a social attribution that permits people to make sense of an equivocal, fluid, and complex world" (p. 7). From the perspective of the cognitive approach, the participants in terms of their understanding of meanings perceive leadership in organizational occurrences (Markus \& Zajonc, 1985). Each person involved in the leadership process is considered to have his or her own implicit theory of leadership in that particular situation (Turley, 2002) expressed in frames, lenses, metaphors, cognitive maps and schema (Marcus \& Zajonc, 1985).

Cognitive models propose that people with low cognitive complexity tend to see things in black and white, whereas those with high cognitive complexity are able to discriminate many 
shades of gray, identify complex patterns of relationships, and predict future events from current trends (Turley, 2002; Yukl, 1994). A high degree of cognitive complexity tends to help leaders conform to prototypical models of what followers expect leaders to be, and understand critical factors and the relationship embedded in them.

There is abundant literature on leadership and its various theoretical bases (e.g., Bass \& Avolio, 1994; Bensimon, 1989; Chemers \& Ayman, 1993; Gardner, 1990; Hackman \& Johnson, 2000). Leadership has been viewed as consisting of traits, behaviors, situational, symbolic and humanistic. It has been studied in multiple venues including business, the military, and education. It often defies description due to its complexity and intangible aspects. Research will continue to assist organizations in achieving their goals.

\section{Bolman and Deal's Four-Frame Model}

Bolman and Deal (1991) defined four organization frames that assist decision making with regard to the specific situation. The Four-Frame model is the result of synthesizing a variety of prior theories, particularly the cognitive, and research to explain how leaders address issues. The frames consist of (a) the structural frame, (b) the human resource frame, (c) the political frame, and (d) the symbolic frame. Each of the frames is a separate perspective with its own assumptions and behaviors. The structural frame views the world from an orderly perspective with formal rules and procedures. The human resource frame assumes that goals will be met by addressing the needs of the members. The political frame involves conflict, alliances, and horsetrading to allocate scarce resources. Finally, the symbolic frame deals with culture, rituals, and symbols as opposed to rules and procedures. Leaders tend to favor one or more of these frames. 


\section{Structural Frame}

The structural frame emphasizes goals and efficiency, formal roles and relationships, and creates rules, procedures and hierarchies (Bolman \& Deal, 1997). Adherence to strength, security of mission, and precision of direction are key to the structural frame (Heimovics, Herman \& Jurkiewicz Coughlin, 1993). Structural leadership emphasizes data analysis, accountability of tasks and goals, a clear mission and tries to solve organizational problems though policies, rules, or through restructuring.

Bolman and Deal (1997) based the structural frame on the following assumptions:

1. Organizations exist to achieve established goals and objectives.

2. Organizations work best when rationality prevails over personal preferences and external pressures.

3. Structures must be designed to fit an organization's circumstances (including its goals, technology and environment.

4. Organizations increase efficiency and enhance performance through specialization and division of labor.

5. Appropriate forms of coordination and control are essential to ensuring that individuals and units work together in the service of organizational goals.

6. Problems and performance gaps arise from structural deficiencies and can be remedied through restructuring. (p. 40)

Previous research in two areas formed the basis for the structural frame (Bolman and Deal, 1997). The work of renowned industrial psychologists Frederick Taylor (1916/1996) and Henri Fayol (1916/1996) and sociologist Max Weber (1946/1996), developed the theories that formed the basis for the structural frame. 
Taylor's (1916/1996) theory of scientific management followed time and motion studies. He created a new division of labor among management and workers that led to dramatic increases in productivity. He believed that every task could be divided into a variety of smaller task components that drastically increase worker efficiency (Taylor, 1916/1996).

Fayol (1916/1996) sought ways to improve administration and developed fourteen principles that served as guidelines for managers. These concepts were designed to be flexible and adapted by the manger. Fayol (1916/1996) proposed that adapting these principles required experience, intelligence, and proportion from the administrator. He also defined administration in terms of five functions: a) planning, b) organizing, c) commanding, d) coordinating and e) controlling (Owens, 1995).

The second theoretical source for the structural frame originated with the work of German sociologist, Max Weber. Weber (1946/1996) conceptualized a well-run bureaucracy featuring rational, impartial, and efficient decision-making. He envisioned bureaucrats that would be highly trained specialists, governed by formal rules with a strong hierarchy of authority (Weber, 1946/1996).

The perspective of the structural frame focused on increased efficiency and specialized roles and functions, capitalizing on vertical and horizontal coordination (Bolman \& Deal, 1997). Therefore, it is the responsibility of leaders to find the best structure to maximize the productivity and efficiency of their organizations.

\section{The Human Resource Frame}

The human resource frame was built upon the concept that "organizations can also be energizing, productive, and mutually rewarding” (Bolman \& Deal, 1997, p. 102). 
Heimovics, Herman, and Jurkiewicz Coughlin, (1993) postulated an organization's members constituted its greatest resource. Human resource leaders concentrate on feelings and relationships, and seek to lead through support and empowerment. In essence, they seek to align the needs of the organization with the needs of the individuals (Bolman \& Deal, 1997). Bolman and Deal (1997) based the human resource frame on the following assumptions: 1. Organizations exist to serve human needs rather than the reverse. 2. People and organizations need each other; organizations need ideas, energy and talent; people need careers, salaries and opportunities.

3. When the fit between individuals and system is poor, one or both suffer: individuals will be exploited or will exploit the organization or both will become victims. 4. A good fit benefits both: individuals find meaningful and satisfying work and organizations get the talent and energy they need to succeed (Bolman and Deal, 1997, p. 102).

The experiments conducted at Western Electric Company's Hawthorne plant in the 1920 's were the genesis of the human resource movement. Roethlisberger (1941/1996) explained that workers are not isolated, unrelated individuals. He contended that they were social animals and should be treated as such. The Hawthorne experiments emphasized the need to understand human motivation and behavior to effectively motivate employees.

Abraham Maslow's (1943/1996) famous Needs Hierarchy formed another theoretical basis for the human resource frame. His theory proposed that people are motivated by a variety of needs. These needs were divided into a five-category pyramid beginning with fundamental physiological needs and progressing to the complex need of self-actualization. The lower need dominates human motivation until that need is satisfied, then the higher needs govern actions. 
The categories were physiological (food, water, air), safety (safe from danger and the elements), love (belonging and acceptance by others), esteem (feel valued and value oneself), and selfactualization (to maximize personal potential).

Douglas McGregor (1957/1996) built on Maslow's theory by adding the concept that managers' predisposed assumptions of employees determine how they respond (Bolman \& Deal, 1997). McGregor argued that most mangers believed in Theory $X$, which viewed employees as lazy, lacking ambition, preferring to be led, disliking responsibility, and being indifferent to organizational needs. McGregor argued that managers should adopt the concepts of Theory Y which believed that "motivation, the potential for development, the capacity for assuming responsibility, the readiness to direct behavior toward organizational goals are all present in people" (p. 180). McGregor felt that it was management's tasks to set up the organizational conditions in ways that would best allow employees to achieve these goals through their own efforts. He argued that Theory $\mathrm{Y}$ was a process of introducing opportunities, utilizing individual potential, disassembling barriers, encouraging growth, and providing leadership.

Hertzberg (1968/1996) claimed that the way to motivate workers was to provide job enrichment. Job enrichment variables were responsibility, recognition for achievement, the work itself and growth or advancement. Senge (1990) felt that the best leaders were interested in fostering teamwork. They are open to new ideas and teaching but are also able to instill in others the determination and confidence to work as a group when problem solving.

Universities are especially susceptible to ignoring the tenets of the human resource frame. Becker and Lewis (1994) determined that fostering creative leaders for higher education requires an investment in its employees. However, Bennis (1989) found that "routine work drives out non-routine work and smothers to death all creative planning, thus killing all fundamental change 
in the university or any institution" (p. 222). Therefore, universities should focus on fostering individual creativity and strategic planning to ensure the growth and success of both the institution and the employees who serve it.

Bolman and Deal (1997) expounded on the problems that develop when the organization fails to take into account the sensitive relationship between the people and the organization. When the "fit between people and organizations is poor, one or both suffers: individuals may feel neglected or oppressed, and organizations sputter because individuals withdraw their efforts or even work against organizational purposes" (p. 119). The Human Resource frame is an offshoot of the Blake and Mouton Managerial grid (1976) and Hersey and Blanchard Theory of Situational Leadership (1982). If the leader is able to obtain a good fit between people and the organization, mutual benefits can be found. Organizations that emphasize the human resource perspective benefit from people finding purposeful and rewarding work that translates into the organization getting the dedication, talent, and drive needed to succeed (Bolman \& Deal, 1997).

\section{The Political Frame}

The political frame focuses on the ever-present conflict and maneuvering by various groups and interests over an organization's finite resources. The political frame views organizations as vibrant, forceful political arenas where a multitude of individual and group interests vie for attention (Bolman \& Deal, 1997). Heimovics, Herman, and Jurkiewicz Coughlin, (1993) contended that "politically oriented leaders not only understand how interest groups and coalitions evolve, they can also influence the impact of these groups upon the organization (p. 421).

Bolman and Deal (1997) proposed five assumptions to summarize the political perspective: 
1. Organizations are coalitions of various individuals and interest groups.

2. There are enduring differences among coalition members in values, beliefs, information, interests, and perceptions of reality.

3. Most important decisions involve the allocation of scarce resources-who gets what.

4. Scarce resources and enduring differences give conflict a central role in organizational dynamics and make power the most important resource.

5. Goals and decisions emerge from bargaining, negotiation, and jockeying for position among different stakeholders (p. 163)

The first assumption deals with the emergence of coalitions. Bolman and Deal assert that a coalition forms due to mutually defined membership roles. Members need each other even though their goals may only be partially compatible. These similar goaled groups form coalitions that band together to lobby on specific issues (Mitzberg 1983/1996). Each coalition has its own beliefs, values, preferences, interests, perceptions, and perspectives (Shafritz \& Ott, 1996). These differences lead to competition and conflict. Bolman and Deal maintained that the enduring differences implied that "political activity would be more visible and dominant under conditions of diversity than under conditions of homogeneity" (p. 164).

The third assumption includes the allocation of scarce resources. Shafritz and Ott (1996) argued that competition among coalitions occurs continuously over scarce organizational resources. Minimal political activity occurs during times of abundant resources. However, scarce resources heralds increased political posturing by each faction to get its fair share of the resources (Bolman \& Deal, 1997).

The fourth assumption of the political frame centers on the distribution, allocation and exercise of power. French and Raven (1959/1996) outlined five bases of power: reward, 
coercive, legitimate, referent, and expert. Each of these power types reflects the qualitative variable that defines the interactions between personalities. Pfeffer (1981) argued that politics involved the exercise of power to achieve a specific task. Kanter (1984) affirmed that power brings two kinds of capacities, "first, access to the resources, information and support necessary to carry out a task; and second, ability to get cooperation in doing what is necessary" (p. 401). Consequently, the skill involved in the effective utilization of power will determine the political skill of a leader (Mintzberg, 1983).

The fifth assumption of the political frame emphasized that managers do not set the organizational goals. The goals are derived at "through an ongoing process of negotiation and interaction among the key players" (Bolman \& Deal, 1997. p. 165). The final results of these negotiations are rarely indicative of the goals of any one group or coalition within the organization (Pfeffer, 1981).

Bolman and Deal assert that the use of power is a normal and inherent part of an organization's maturation process. The competition for resources and power disrupts the status quo and compels organizations to seek workable solutions. Owen (1995) supported this concept and reasoned that conflict forced organizations to find successful ways of resolving it, therefore providing improved organizational performance. The power exercised within an organization should be used to assist the people, not paralyze them.

The Symbolic Frame

Bolman and Deal (1997) developed the symbolic frame to explain how organizations could be seen as cultures "propelled more by rituals, ceremonies, stories, heroes, and myths than by rules, policies, and managerial authority" (p.14). The flexibility of the symbols and culture 
allow leaders to capitalize on rituals, ceremonies, or artifacts to create a unifying system of principles (Heimovics, Herman, and Jurkiewicz Coughlin, 1993).

Bolman and Deal based the symbolic frame upon the following assumptions:

1. What is most important about any event is not what happened but what it means.

2. Activity and meaning are loosely coupled: events have multiple meanings because people interpret experience differently.

3. Most of life is ambiguous and uncertainly undercut ration analysis, problem solving and decision-making.

4. High levels of ambiguity and uncertainty undercut rational analysis, problem solving and decision-making.

5. In the face of uncertainty and ambiguity, people create symbols to resolve confusion, increase predictability, and provide direction, and anchor hope and faith.

6. Good symbolic managers are courageous. They have the courage of their convictions. They resist the temptation of fixing the problem themselves (Deal and Kennedy, 1982).

Myths, fairy tales, and stories convey the value and identity of the organization to insiders and outsiders, thereby building confidence and support (Bolman \& Deal, 1997). Culture allows people to explain uncertain and ambiguous events. Rituals and ceremonies provide clarity, predictability, and order. Metaphors translate convoluted issues into understandable concepts, affecting our way of thinking, assessment, and performance (Bolman \& Deal, 1997).

These rituals, myths, heroes, and symbols convey an organization's culture. Owens (1995) maintained that an “organization's culture develops over a period of time and in the process of developing, acquires significantly deeper meaning" (p. 82). Organizational culture is a body of solutions that work consistently and are taught to newcomers. Kilmann and others 
(1985) linked organizational culture to a human personality. They equated organizational culture to an invisible, intertwined theme that provided meaning, direction, and desire for action (Kilmann et. al., 1985). Schein (1985/1996) claimed that the most important function of a leader is to create and maintain a creative, purposeful organizational culture. Clark (1998) asserts that organizational cultures in higher education are created by a variety of groups. The faculty constitutes the core group of believers, followed by alumni and student subcultures who hold deep beliefs about the institution. Sergiovanni, Burlingame, Coombs and Thruston (1992) argued that " the more understood, accepted and cohesive the culture of the school, the better able it is to move in concert toward ideals it holds and objectives it wishes to pursue" (p. 159). Jeffcoat (1994) asserts that presidents often describe themselves through metaphors of self, which serves to augment images of presidential leadership. The images they create function as composite images to bolster their power and influence.

Deal and Kennedy (1982) assert that organizations develop their own unique identities by influencing beliefs, creating heroes, utilizing rites and rituals, and acknowledging the values of the culture thereby given them an advantage over competitors. These humanistic organizations provide employees with purpose, both within and outside the organization (Deal \& Kennedy (1982/ 1995). Leadership, then, is a subjective act as the leader's vision weaves a new reality that is desirable to the followers and their beliefs (Bensimon, et al., 1989).

In summary, each frame has its own unique characteristics. Table 4 depicts some major aspects of the theory. 


\section{Table 4}

Characteristics of the Bolman and Deal Four Frame Model*

Characteristics Structural

Metaphor

Machine

Central Concepts Rules, roles, policies

Decision Making Rational

Leader

Analyst, architect

Process

Analysis, design

Communication Transmit facts

Motivation

Economic

Challenge Attune structure to task Align needs

* Adapted from Bolman and Deal, 1997.

The Multi-frame perspective

The four-frame model provides a decision-maker the opportunity to view organizational problems with a new perspective in order to create viable solutions. Bolman and Deal (1997) state, "Organizational life is always full of simultaneous events that can be interpreted in a variety of ways" (p. 266). The multi-frame model provides a framework to examine every situation and event from multiple viewpoints. A leader that is able to use multiple frames is more likely to be successful that one who attempts to solve organizational problems from an inappropriate or single perspective. A leader that is able to use multiple frame is more likely to be successful than one who attempts to solve "organizational problems from an inappropriate or single perspective" (Heimovics, Herman \& Jurkiewicz Coughlin, 1993, p. 421). Bolman and 
Deal (1997) concurred and asserted that a leader's capacity and talent to reframe their experiences enhances and expands a leaders range.

Bolman and Deal (1997) acknowledged that the use of multi-frame thinking offers the potential of powerful new alternatives but carries the inherent threat that not every new policy will be successful. The multi-frame process requires aptitudes and is often counter intuitive. The successful process requires "artistry, skills and the ability to see organizations as organic to provide direction and shape behavior. The ability to see new possibilities and to create new opportunities enables leaders to discover alternatives when options seem severely constrained" (p. 380).

Related Research

The Bolman and Deal leadership model has been utilized in a number of studies both inside and outside of higher education. Tingey (1997) sampled 418 higher education presidents and found that college leadership was contextual and situational in nature since certain types of institutions tended to have a president with a specific style of leadership. Using the Bolman and Deal (1990) Leadership Orientations instrument, Jablonski, (1992) found that the majority of female college presidents utilized the structural frame. Echols Tobe, (1999) found two thirds of female African American had multiple frame orientations.

Other higher education research included academic affairs, student affairs, public safety and chief information officers. Becker (1999) studied chief information officers and found significant relationships between gender and use of the structural and human resource frames. Further, multi-frame leadership was used by two thirds of the respondents. Cantu (1997) studied deans at Masters and Doctoral institutions and found the human resource frame was primarily used followed by the structural, then political, and finally the symbolic leadership frames. Travis 
(1996) studied senior student affairs officers and found the human resources frame was the preferred frame used. Kane (2001) examined mid-level student affairs administrators and likewise found the primary use of the human resources frame. Wolf (1998) examined 343 campus safety directors at public four-year institutions and found the human resource frame was the principal frame utilized by the campus safety directors, and two-thirds utilized multiple frames. Redman (1991) compared the leadership frames of private Japanese and American higher education institutions and found a significant difference in all leadership orientation frames in the total Japanese and American sample. However, when the subset of Christian universities was dropped from the sample, the only significant difference was in the political frame. Borden (2000) studied campus administrators in Florida's state university and community college systems and found the human resource frame was primarily used, followed by the symbolic frame, the structural frame and finally the political frame. Multiple frames were used by nearly half of the respondents.

Russell (2000) examined the leadership frames of community college deans and found the human relations frame the most prevalent. Further, deans with multiple leadership orientations reported lower stress, higher satisfaction and lower role-conflict compared to those deans who used one primary leadership orientation.

In the field of health sciences, Mosser (2000) studied the relationship between the perceived leadership style of nursing chairpersons and the organizational climate in baccalaureate nursing programs. She found faculty members perceived their chairpersons to use the human resource frame the most, followed by the structural frame, the symbolic frame, and the political frame. Turley (2002) studied radiation therapy program directors and found the human resource frames followed by the structural frames were utilized the most. Forty-four 
percent of respondents espoused multi-frame leadership. Small (2002) examined the relationship between the perceived leadership style of nursing chairpersons and the organizational effectiveness of baccalaureate nursing programs. It was interesting to note that chairs were perceived by faculty members as using no frames the most, followed by all four frames, single frame, multi-frame, and paired frame. Of the single leadership frames, faculty perceived chairs to use the human resource frames the most often. The structural frame, symbolic frame, and political frame followed in usage.

Many studies were conducted in the area of primary and secondary education. Suzuki (1994) compared the leadership of California Asian and other public school principals. He found females utilized the human resource frame more often than males, and foreign-born utilized the structural frame more often than U.S.A.- born and a larger number of Asian-American principals who used multiple leader orientations. Ulmer (2002) examined the principals' leadership practices in the context of state assessments and found that most implemented practices fell within the structural framework, and the practices implemented the least fell within the political framework. Rivers (1996) studied principal leadership in Florida and found the human resource frame was the dominant leadership orientation frame, followed by the structural, then symbolic and finally the political frame. More than one half of the elementary principals utilized multiple frames and three quarters of the high school principals utilized multiple frames. Cote (1999) studied the leadership orientation frames of Florida elementary principals. She found the structural frame was stronger for those with less education. A significant relationship was indicated between human resource frame use, and tenure with gender. Messer (2002) also studied elementary principal leadership orientations in Florida public schools and found the human resource frame was the predominant frame used by the principals, followed by the 
structural frame. The use of multiple frames was reported by $60 \%$ of the principals. Harlow (1994) studied twenty Washington State public school superintendents and found they most utilized the human resource frame, followed by political, structural, and symbolic. These superintendents rarely used more than two frames and Flak (1998) examined female superintendents and found multi-frame leadership orientation was used.

Bensimon (1989) studied presidential leadership styles utilizing the Bolman and Deal framework. She found the majority of presidents in her sample had a single frame orientation. Other presidents utilized a paired frame orientation where two frames were used. The collegial/symbolic pairing was cited as being most practiced. Another group employed a multiframe orientation where leadership was practiced from three vantage points. In addition, Bensimon (1989) compared frame usage with the presidents' length of tenure and institutional type.

The Presidency

The following sections highlight recent research on various aspects on the role of: presidential leadership, gender, race, and career path. The variables often intersect and are paired in various research studies.

Murphy (1997) noted that the American college president is under attack from a variety of sources. This observation could explain an average turnover rate of nearly $50 \%$ for the almost eight hundred colleges and universities from 1986-1991. (Commission on Colleges Annual Report 1991) Consequently, the presidency at American colleges and universities is increasingly becoming a revolving door.

Some fear that presidents have lost their academic edge. Instead of being the chief academic officer of the institution, the primary role for the president has become that of chief 
fundraiser. Fundraising is central to the well being of most institutions and the research tends to support this assertion. Hurtubise (1988) found that presidents at select, small, independent, liberal arts colleges believed they were responsible for creating the fund raising climate and that it was their highest priority as president to seek financial support for their institution. Janney (1994) studied presidents of the Christian College Coalition and found that the president's administrative style may be directly related to the fund raising effectiveness of the institution. Although presidents now spend the most time on fund raising, advancement professionals however have a difficult road to the office since they generally have a limited academic background. To be seriously considered by the search committee, a candidate must have academic credentials that include a Ph. D., teaching and publications (Fisher, Tack \& Wheeler, 1988). Further, the need to keep donors and other stakeholders satisfied may reduce presidents' willingness to engage in controversial subjects. In fact, it is feared that the presidency has decayed and is "often a refuge for ambivalent, risk-averting individuals who seek to offend no one, and as a consequence arouse and motivate no one" (Fisher \& Koch, 1996, p.viii).

Clearly, the presidency is in need of individuals who have powerful ideas and can provide leadership by translating these ideas into practice in higher education (Levine, 1998). However, an unfortunate consequence of the selection process is the elimination of potential intellectual and educational leaders in favor of men and women who look, speak, and act like candidates for political office. Thus, candidates with winning personalities have an advantage over committed academic thinkers (Lovett, 2002). The search process for a president is time consuming, extensive and potentially draining. It can also be poorly managed, personally dissatisfying, and in some cases even demeaning for the candidates. Although candidates reveal their inner workings, the boards and institutions seeking to hire them often do not. Eighty-three 
percent of presidents commented that a significant problem, generally dealing with finances, had not been disclosed to them before they took office (Basinger, 2001).

But how do presidents learn their job? Siegel (2001) found major themes characterized presidential learning during the first year. Since colleges and universities are complex organizations, it follows that learning to be a college president is similarly complex. The research suggests that presidents must engage in array of activities during their first year in office in order to learn, and convey a respect for, the core tenets of campus culture. New presidents commented that nothing prepares one for the presidency. They had to discover, respect, and utilize elements of institutional culture to communicate thoughts and ideas and never to underestimate the role of symbolism. Further, Smith (2001) studied presidents of private institutions in New England serving in their first presidency and found individuals with remarkable stamina, productivity and perseverance, ability to make connections with constituencies to achieve institutional goals, and manage a web of temporal, physical, social, cultural and community influences. Issues related to spirituality emerged and imply that the ability to be mindful and attach personal meaning to one's life is a central consideration. The presidency is context bound and that increased attention to the personal aspects and meaning of being a president within the context of a particular campus community may be key to effective presidential leadership.

Even though power has been shared with faculty and student groups and has been diminished through government intervention, Kerr and Glade (1987) contend the presidency itself has become more important to the institution as a whole. A president of an institution of higher education carries a greater level of credibility than ordinary citizens or most leaders in business and politics (Murphy, 1997). To paraphrase an advertising slogan, “when presidents talk, people listen." Nelson (1996) affirmed that college presidents often become highly visible 
leaders and have the ability to exert influence within their educational communities and the larger society. Pullias and Wilburn (1984) assert, “... as the chief voice for the institution, its purposes, processes, and goals must not be taken for granted, but must be stated again and again" (p. 11). Further, the president has a moral voice that emerges as an essential contributor to the institutional philosophy and mission. Keohane (2003) commented on presidential speaking, since anything a president says about a controversial issue while in office can be taken as an official statement for the institution. This reality makes it very difficult to separate the person from the position. The easiest cases to speak out on are those in which a topic has clear relevance to the other public purposes of the institution; it becomes progressively harder. Therefore, when taking a controversial stand is overused, moral authority can be diminished. However, if the "bully pulpit" is never used, what is the use in having it? There are times when presidents should speak out on an issue; however, the potential consequences for the institution should be considered as well.

\section{Presidential Leadership}

Leadership has been described in terms of traits, behaviors, power and authority. Furthermore, the nomenclature of leadership is often characterized as masculine and the focus has been on male leaders (Komives et al. 1998). There is abundant literature on leadership style, perceptions of leadership, and specific demographic variables concerning leadership. Levine (2000) examined the presidential style at fifty national universities and found transformational leadership was the preferred style of nearly three-quarters of presidents. In addition, transformational leadership was found to induce the greatest satisfaction among followers. Transformational leaders have also been studied in community colleges. Hensley (1998) found institutional mission, consensus-team building, risk-taker, campus-community culture, 
empowerment, communication, and trust-respect were key effective leadership characteristics used and considered essential for success by presidents in Montana. Similarly, Shaw (1999) contends that community involvement in decision-making is crucial in initiating change. Cobelli (1989) found that organizational structure and size determined the way administrators made decisions. The power and gender of the administrator affected her or his participation in the decision process and the way that decisions were made.

Attributes of the leader or the situation affect the leadership style. Mchugh (1991) found that an excellent president is a decision maker, visionary, team builder, listener, role model, mentor, educator, and fundraiser. Shaw (1999) declares that it is the presidents' responsibility to create a fertile environment for change. He asserts "Leaders are the keepers of the climate of renewal" (p. 58). Minor (2001) found an effective leadership team, multi-level engagement, and practicing process flexibility were keys to university presidents' leadership style. Botstein (1985) declares, "the president must inspire and bring the best out of all the constituent elements within a college" (p. 111). Agbor-Baiyee (1996) studied the factors that motivate and provide satisfaction for college and university presidents and found a desire for meaning, personal growth and development, providing academic leadership, and making a contribution to the higher public good as power factors that influenced presidential leadership. Wise (1984) examined the environmental status and leadership behavior of liberal arts college presidents and found that institutional factors (academic status, size and location of the colleges) did not significantly influence the leadership behavior of the college presidents; however, faculty characteristics of position, rank and age of the faculty members making the assessment influenced their perceptions of the college presidents' leadership behavior. These findings suggest that although presidential leadership behaviors were influenced by certain faculty 
characteristics, overall, small private liberal arts college presidents exhibited similar leadership behaviors regardless of variations in institutional characteristics.

A study was conducted to compare the presidents of the 30 best southern colleges and universities as named by U.S. News \& World Report in 1987 to other representative institutions. Those presidents served longer terms, devoted more time to external constituencies, and spent less time with internal groups. While they worked an average of 61 hours per week, over half expected to work longer hours in the future. Fund raising-external relations, financial-general administration, academic matters, and student activities consumed the majority of their time. These presidents predict increasing commitments for external relations (particularly fund raising), academic matters, and student activities, while decreasing time for financial and general administration (Dyson, 1988).

Perceptions of presidential leadership have been studied as well. Bethel (1998) examined the relationship between presidential leadership orientation and organizational effectiveness of 288 presidents and administrators from 72 Bible colleges. A statistical significance between the four presidential leadership orientations and the four domains of organizational effectiveness in three of the sixteen research questions were identified. The Colleges of the City University of New York served as the target population for Coleman's (1987) inquiry into the leadership styles and perceptions of authority of presidents. The findings indicated that there was no overall significant relationship between the leadership style and perception of authority of presidents of colleges that are a part of the multi-campus system involved in this study. There was, however, a significant relationship between the ages of the students and perception of authority as younger students perceived the president to have more authority. Similarly, the presidents were perceived to have greater authority if their institutions were older. There was a significant relationship 
between leadership style and age of the president. Younger presidents perceived their leadership style as more participative. There was a significant relationship between personal longevity in the City University system and perception of authority. Ironically, the shorter time the president had been in the system the more authority the president perceived he or she had. In summary, leadership style is not a sound predictor of the president's perception of his or her authority or power.

In a similar way, the perceived leadership style of the presidents in the Pennsylvania State System was conducted. The findings indicated a significant positive correlation between the university presidents' perception of his or her adaptability and the years employed full time in higher education (Truschel, 1997). Under the tutelage of the renowned James G. March, Castro (1998) studied presidential optimism and leadership. He found that presidents use more positive than negative language, were more optimistic at the beginning of their term than at the end, and each of the presidents who exhibited a decrease in optimism was a first-time president. Optimism can be construed as symbolic and the realities of the position both positive and negative become realized when one is in the position.

Zhang (1993) examined the risks of presidential leadership in small private colleges and found that presidential leadership and risk taking emerged. The presidents acknowledged that risk taking is inevitable in their roles as institutional leaders, and that leadership differs from management. These presidents used several key strategies to manage the risk of leadership, including defining vision, communicating vision, and encouraging ownership of vision. This study confirmed the importance of risk taking and vision building to leadership.

It appears the longer president serves, the greater the need for strong external relations and less for internal activities. By working a grueling schedule, university presidents often 
become exhausted. They loose their priorities, neglect relationships with family members and friends, and suffer personal isolation and intellectual starvation. To remedy this situation, it is suggested that serious reading, continued teaching, meaningful research, and the cultivation of their inner life be pursued (Rhodes, 1998). In a study of leadership style and its relationship to "burn out" between 134 four-year and community college presidents in seven western states, Gubanich (1991) examined situational leadership of presidents and found use in the "selling" and "participating" categories. These presidents did not demonstrate "telling or "delegating" modes of leadership. Presidents utilizing selling tended to be in office longer, were in larger institutions, and experienced greater burn out. Presidents of smaller schools, who tended to be younger, and less prone to burn out, utilized participating style more. It was interesting that only the leadership style of the president was considered as the Hersey and Blanchard model because leadership is also dependent on the maturity of the followers. This is significant since Fujita (1990) found what the leader of any organization can accomplish depends to a great extent upon whether or not followers decide to lend their support. Presidents were evaluated according to the extent to which they were perceived to share their power and meet expectations deriving from the symbolic nature of the presidency. Bechtle (1993) studied the leadership style and stress among Bible College presidents and found no significant statistical relationship between leadership style flexibility, leadership style effectiveness and levels of stress. The only demographic variable relating to levels of stress was presidential tenure.

The length of time as a president appears to correspond to the type of leadership used. Cowen (1990) found significant positive relationship existed between the length of presidents' tenure and increases in full time equivalent enrollment at their current institutions. Other significant relationships existed between perceived presidential leadership behaviors, changes in 
full time equivalent enrollment, and perceptions of effectiveness, subordinate satisfaction, and other factors of the presidency. Significant differences in presidents' style based on years of presidential experience were found (Guill, 1991). Ali (1994) found in Texas Community Colleges the educational level and number of years in administration were significant factors in their choice of a leadership style. Similarly, Lockard (2000) examined the similarities and differences in leadership style in university presidents. Male and female responses were evenly matched in percentage response rates. The single category that had some differences was in the length of service as a president.

Fullagar (1989) examined new presidents of four-year colleges and universities during the timeframe of 1980 - 1988 and found enrollment decreases in public and in non-doctorategranting institutions, and increases in doctorate-granting colleges and universities were associated with the selection of outsiders. The significance of this finding is that for better or worse, new presidents come from outside of the institution. Other studies have confirmed that over three-quarters of new presidents come from outside the institution (Ross \& Green, 2000).

Interim presidents are caretakers for the institution until the next president is selected. Trudeau (2001) studied eight interim presidents at Masters institutions in Minnesota and Wisconsin and found that all relied upon consensus leadership. This is an important finding since the consequences of turnover at the top can be immense. Searches often take an academic year to complete and institutions can lose momentum in planning, fund raising, and staff morale and productivity (Basinger, 2001).

\section{Gender}

Females constituted only $10 \%$ of the presidents of higher education institutions in 1986. Although severely underrepresented, female participation doubled to $19 \%$ in just twelve years. 
The proportion of males to females in Masters I institutions parallel the gender ratio in total institutions. Currently, women account for $25 \%$ of the new presidencies (Ross \& Green, 2000). However, a disproportionate number of women headed private institutions with enrollments under 4,000 (Mancini, 1993).

Since males dominate the presidency, the female perspective has been covered extensively in the literature. Pierce (1992) found female administrators succeeding in this maledominated setting by possessing the leadership characteristics of a high degree of intelligence, perseverance, integrity, high motivation and organization, vision and people orientation, and excellent decision-making skills. The feminine leaders were extremely conscientious, task oriented, able to work collegially, and sought collaboration. Kelts (1998) conducted case studies of three women college presidents in New England to determine how female leaders define power. She found that the traditional concept of power in an academic collegiate environment is applied more in a cooperative way than in a private corporate setting. The leadership approach focused on goal accomplishment through cooperation and involvement of their constituents. The presidents cited the factors of building trust as a base for partnership, creating a learner-centered organization, developing a caring relationship, sharing information and knowledge, and empowering people as components in building a community.

Are women's leadership styles different than men's? Sawyer (1996) found female presidents prefer a participative approach to leadership, but face limitations in how participative they can be. However, if they are perceived as too authoritarian, they are criticized as acting like men. Guill (1991) examined the conflict management style preferences of community college presidents and found no significant difference in style preference based on gender. Ironically, Holder (1993) examined 362 presidents from the total higher education population and found 
levels of Machiavellianism were greater in female presidents than in male presidents. The females in that study were more authoritarian than their male counterparts.

Wheeler and Tack (1989) contend that women are rarely represented in top academic administrative positions in higher education due to sex discrimination, negative perceptions of them as administrators, and negative evaluation of their administrative performance. They hypothesized that there is a difference between the leadership behaviors and attitudes of male and female college presidents. However, they found that male and female college presidents maintain similar overall leadership behaviors and attitudes. The differences in responses were based on the administrator's years of experience in higher education rather than on gender. However, Buddemeier (1998) found that $81 \%$ of female community college presidents experienced sex discrimination on their pathway to the presidency.

Male and females presidents displayed no significant difference in the perceptions of their gender role identity (Overland, 1996). Similarly, Kisling (1986) found no statistically significant differences between women presidents of two-year and four-year institutions of higher education on the basis of social origins, education, and career patterns.

Chliwniak (1996) found that gender and position provides significant influences on perceptions. She contends the gender gap in higher education has more to do with assumptions than perceptions, and with inequity rather than difference.

Race

Race is proportionately a minor factor in the composition of college and university presidents. There is ample evidence that Caucasian males constitute the overwhelming majority of positions. Despite this fact, the variable of race is well represented in the literature. Studies have shown that from 1986 to 1998 , the percentage of minority presidents at all higher education 
institutions increased from $8 \%$ to $11 \%$ and the percentage at Masters I institutions increased from $13 \%$ to $15 \%$. Table 5 depicts this change in ethnic composition. Even though African Americans made the greatest gains nationwide, Asian American presidents increased the most at Masters I institutions. Furthermore, although the percentage of diversity at Master I institutions was greater than the total population of institutions, the relative increase in diversity was slower since Masters I institutions were already more heterogeneous (Corrigan, 2002).

Table 5

Ethnicity Distribution 1986 to 2001 of Masters I and Total Institutions by Percentage*

Total

Masters I Change Institutions Change Variance $2001 \quad 1986$ $2001 \quad 1986$ Master/Total

\begin{tabular}{lrrrrrrr} 
African American & 7.4 & 9.3 & -1.9 & 6.4 & 5.0 & 1.4 & 1.0 \\
Asian American & 1.7 & 0.5 & 1.2 & 0.9 & 0.4 & 0.5 & 0.8 \\
Caucasian & 87.1 & 87.2 & -.1 & 87.5 & 91.9 & -4.4 & -.4 \\
Hispanic & 3.0 & 2.6 & 0.4 & 3.2 & 3.7 & -.5 & -0.2 \\
Other & 0.7 & 0.2 & 0.5 & 1.6 & 0.5 & 1.1 & -0.9 \\
Total & 100.0 & 100.0 & 0 & 100.0 & 100.0 & 0 & 0 \\
\hline
\end{tabular}

* Corrigan, 2002.

The African-American presidents account for the largest minority, and consequently more research has been conducted on this population. Marbury (1992) found a number of significant relationships between characteristics in the career progression of the African- 
American college presidents studied, including the racial composition of the undergraduate college and gender, the classification and size of the employing institution and between undergraduate college racial composition and the type of the employing institution. No significant relationships were found between characteristics of the professional experience of African-American college presidents as compared to personal factors or in the perceptions of these presidents concerning the relative importance of characteristics such as age, gender, parents' education, and political preference as they relate to career progression. Waters (1993) concluded that presidents of historically black college and universities share the common problem of insufficient funding as a barrier to providing leadership. Minority presidents of private institutions generally employ a hierarchical style of leadership style as opposed to minority presidents of public institutions who employ a collegial leadership style. However, the presidents of public institutions were more satisfied than their private institution counterparts.

Hickerson (1986) found few women and blacks in Tennessee higher education administration and very few held top-level positions. The blacks in higher education held sexually and racially stereotyped positions and were not in the positions of president or vice president. Rouse (1998) compared 76 African-American and Anglo-European community college vice presidents and deans in Maryland, North Carolina, South Carolina, and Virginia and found no significant differences in the self-perception of transformational leadership competencies of each group in the four sub-scales of intuition, influence, people and motivation.

The factor of race has not been found to be a contributing factor in this review of the literature. Spivey (1983) studied the leadership styles and behavior of their respective college/university president by surveying 223 deans and directors from 60 historically Black higher education institutions in the southwestern and southeastern United States. No significant 
difference between the perceptions of deans and directors towards the leadership styles or the behavior of their respective presidents by demographic variables was found. Wright-Tatum (1999) did not find race to be a contributing factor to job satisfaction. Wilson (2002) studied leadership characteristics needed by presidents of historically black colleges and universities as perceived by academic vice presidents. Some academic vice-presidents held specific perceptions of leadership as a result of their years of experience in current positions, the manner in which the presidents performed, the kinds of goals set, and their knowledge of higher education.

Conversely, Robinson (1996) argued that race does play a factor in the community college presidency since it determines who gets into the pipeline for consideration of a presidency.

Another factor in contributing to the lack of minorities in the presidency may be avenues taken which can stall forward progress. Jones (1995) found that administrators hired as directors of student support areas were likely to plateau early in their careers regardless of race. In addition, African Americans are disproportionately represented as directors of support programs. Hence, their career mobility may be more likely to be hindered.

Research on other minorities was conducted by Gorena (1994) who studied Hispanic women in higher education, and by Mata (1997) who likewise profiled Latino community college presidents. Hispanics had to contend with a lack of cultural capital, cultural barriers, and systemic barriers in their rise to the presidency. Becenti (1995) found no significant differences between the self-perceptions of leader characteristics of tribal college presidents and their toplevel staff. There were also no significant differences between perceptions of leader characteristics of the presidents and their staff between the tribal colleges in the study. As more minorities ascend to the presidency, especially at community colleges, more research on this population will be needed. 


\section{Career Paths}

There are various career paths to the presidency. This section will identify candidate profiles, positions leading to the presidency, opportunities, and barriers to the presidency. In addition, some proposes that gender may be a factor in the career path. Much research has been conducted on the small population of female and minority presidents. Kane (1997) found that women have many ports of entry into higher education that leads to the presidency. Females were assisted in their pursuit of the presidency through the help and relationship of a mentor (Davis, 1984; Anglis, 1990, Darby, 1996; Mata, 1997; Buddemeier, 1998; Price, 2000; and Bowyer-Johnson, 2001). This mentoring relationship was especially integral to African American women college presidents (Robinson, 1996; Bowles, 1999; DeVeaux, 1999; Price, 2000). However, Graham (1997) found that mentoring received by African American and Caucasian community college presidents did not significantly affect their career strategies. In addition, Hubbard (1993) found a majority of females in higher education administration utilized networking to help them to obtain their jobs in administration and that females utilized professional groups, organizations, and close associates to obtain their current positions.

The characteristics of women on the road to the presidency included an earned doctorate, experience as a faculty member, and participation in leadership development programs that enhanced their advancement to the presidency (Anglis, 1990). Farkas (1996) found that female presidents of independent baccalaureate colleges had an earned $\mathrm{Ph}$. D. with an undergraduate major in English or History. The majority served as faculty and there was a significant relationship to being a vice president prior to reaching the presidency. Reece (1997) profiled female presidents in the Southeast and found the president had a Ph. D., had been in office five years or less, and in higher education administration for 12-16 years. The hypothesis that 
married women and women with children would be less represented in the presidency was confirmed. Gatteau (2000) found women comprise only $16 \%$ of presidents and they followed the traditional professor route while serving a minimum of 15 years in academics. Reece (1997) studied barriers to women's advancement in the southeast and did not find significant differences in the turnover of women and minority presidents. Kane (1997) found no differences in the career lines for women in two-year and four-year colleges. Women are most likely to first become president from positions in the academic affairs area after starting as faculty members and have fewer jobs than those who did not start their careers as a faculty member. African American women have the same careers, come from the same types of institutions, and have the same entry ports and terminal degrees as Caucasian women. The only significant difference found by race was that African American women held more jobs to reach the presidency. ReedTaylor (1998) outlined career paths, mobility patterns, and experiences of two-year college women presidents of color. Mata (1997) profiled Latino community college presidents and found factors that led to the presidency included luck, making geographic moves, going beyond the call of duty, Latino consciousness, and encouragement. Arnold (1994) conducted a descriptive study of the characteristics of female African American presidents. When asked how being both a racial minority and female affected their rate of career progression, most of the women indicated their dual status had worked for them, rather than against them. Conversely, Greer (1981) found that felt that race and sex had an adverse affect on their careers although Arglis (1990) found that affirmative action legislation did not have a direct influence on their career progression.

The pathway to the presidency has consistently been through academic affairs. Almost $60 \%$ of the effective college presidents began their careers as faculty members and the position of vice president for academic affairs or provost appears to be the last position held before 
assuming the presidency (Fisher, Tack \& Wheeler, 1988). However, Ross and Green (2000) found that the prior position held most often at Masters I institutions (and for the total higher education population) was a president at another institution. Sterneckert (1980) studied presidents from a sample of public and private four-year American institutions, excluding all church-related schools, and found that $87 \%$ had faculty experience and $80.5 \%$ were promoted to the position from outside the institution after spending five and a half years in their previous position. Presidents of public institutions had 19 years of higher education experience while presidents of private colleges had 16.5 years of experience. Mathern (1998) studied the leadership strategies of university presidents and found that the career path is from a faculty position to administrator to the university president.

The traditional career path through academics is not etched in stone as significant variances in this route have been found. Smith (1996) studied 91 presidents at small religious college presidents and found only one president followed the normal presidential career trajectory (faculty-department chair-academic dean-vice-president for academic affairspresident). One third of the presidents by-passed three positions, and one fourth, by-passed four positions on their trek to the presidency. Long (1980) studied the career patterns of 928 top level administrators from 210 four year evangelical liberal arts and bible colleges, and Salimbene (1982) sampled 4-year institutions, finding the normal career path does not represent the actual career experiences of current college and university presidents. Fifteen career path variations were identified and determined that the majority of presidents held faculty rank during their career progression. Lagakis (2001) conducted a national study of the 92 female Masters I and Masters II female presidents and created a demographic profile, career progression of principal career progression, and variations in career progression. More presidents came from outside of 
the faculty ranks. In 1986, only $25 \%$ of presidents had not been a faculty member. By 1998 , this percentage of had risen to $30 \%$ (Corrigan, 2002).

Fund raising is another avenue to the presidency. As a result, faculty service has diminished and benefactor experience increased among university presidents (Mathern, 1998). Since fund raising is of integral importance, it would benefit candidates to gain this experience. Prospective female candidates need to become more engaged in fund raising, specifically at larger institutions. Williams (1981) found that women have not penetrated top-level educational fund raising administration at medium and large size institutions. The majority of women vice presidents for development and college/university relations were employed in small private coeducational institutions with student enrollments of less than 5,000.

The position of interim presidents results in a permanent presidency for $30 \%$ of candidates. Interim presidents handled the tasks normally associated with the presidency and used it as a bridge to obtaining a permanent position. The interim presidency was seen as a leadership role shaped by situational and temporal degrees of management with power and authority being concentrated at the beginning of the tenure. Everley (1993) examined the interim presidency at 134 public research/doctorate-granting institutions and found the majority of interim presidents were males and were chosen from within their own institutions from the chief academic affairs position. It was interesting to note that after a candidate had become president, they gained a greater appreciation for executive-administrative backgrounds, fund raising, planning and delegating skills, and the energy and sense of humor needed for the office (Dyson, 1988).

Finally, as a preview of future presidents, Krampien (1995) examined academic deans at small liberal arts colleges in the mid-west. Not surprisingly, the majority of the academic deans 
were white males, who on average were 52 years old, married, had served as a faculty member for 19 years, and had experience as a department chair.

Presidents of the "Middle Child of Public Higher Education"

Ross and Green (2000) examined all institutions for the American Council of Education to gain valuable demographic information. However, no research has been done on the leadership styles, of presidents in this section nor was there investigation of any correlation between demographic variables and presidential leadership styles.

A number of doctoral dissertations gathered demographic data to form a composite view of the presidency. These studies included very small discrete populations including Kelts' (1998) case study of three women college presidents in New England, Krumm's (1997) investigation of four American Indian women tribal college presidents, Freeman's (1993) profile of the 25 African-American women presidents. At the other end of the spectrum, the American Council on Education periodically surveys all institutions of higher education on a number of demographic variables. Many studies sampled both public and private institutions, concentrated on the public or private only, or selected a particular segment to study. For example, Smith (1996) studied presidents of small religious colleges, Long (1980) examined four year liberal arts and bible college presidents, Krampien (1995) chronicled academic deans at small liberal arts colleges in the mid-west, and Salimbene (1982) researched a sampling of presidents at 4-year institutions on career path of presidents.

Women presidents were the focus of much research. Lagakis (2001) conducted a national study of the 92 female Masters I and Masters II female presidents and created a demographic profile and career progression of principal career progression and variations in career progression 
but did not address leadership. Anglis (1990) studied 14 women administrators in a midwestern state, and Kisling (1986) compared women presidents of two-year and four-year institutions, Much research has been conducted on predominately religious institutions. Wessel (1991) profiled the career patterns of private, four-year college and university presidents and found the ratio of males to females was $81 \%$ to $19 \%$, Caucasians accounted for $92 \%$ of the presidents, $75 \%$ were married, and 66\% were Protestant. Significant differences were found among the types of control and Carnegie classifications including: 95.8\% at Doctorate-Granting were male compared with $77.3 \%$ at Liberal Arts Colleges; the average age at Liberal Arts Colleges (54.0) was younger than at the Doctorate-Granting (57.6) and Comprehensive (56.4); over $95 \%$ of the Protestant college presidents were married and $79 \%$ of Roman Catholic college presidents were single. Presidents who are catholic clergy are celibate and thus the variance can be explained. Similarly, Rittof (2001) studied catholic higher education institutions.

Conversely, other researchers focused only on public institutions. In a study of newly appointed presidents in institutions that were not church related. Sterneckert (1980) surveyed 262 presidents and found that for 202 or them, this was their first presidency. The composition profile did not vary in any noticeable degree from previous studies like Cohen and March (1974), Ferrari (1970), and Demerath, Stephens and Taylor (1967). This study supported an unchanging observation that academic chief executive officers are middle-aged, married, male, protestant and academicians. Other studies confirm the relative constancy of the recipients of the presidency. Shawver (1985) compiled a portrait of the 65 presidents who are members of the American Association of State Colleges and likewise found the majority of presidents held doctorates, were white, male, married, and protestant. Barr (1981) found that the profiles of American College presidents in 1968 accurately described the 1980 college presidents as well. Finally, the 
American Council on Education compared presidential characteristics for 1986 and 1998 and illustrated that change is occurring albeit at a very slow rate.

It appears that the size and type of institutional control affects leadership styles. Macera (1989) studied critical presidential managerial skills and found statistical significance in the ratings based on gender and the size of institution. However presidents maintained that the skills needed were different for public and private institutions. Findings relative to gender, excellence and organizational structure appear to be consistent with previous studies. Juhan (1993) found significant relationships between role ambiguity and role conflict, role ambiguity and role frustration, role ambiguity and job satisfaction, and role conflict and role frustration in presidents at private 4-year colleges in the Southeast and Gubanich (1991) concentrated on the leadership style and its relationship to burn out among 134 four year and community college presidents in seven western states.

All of these studies provide a plethora of data, but none of these have addressed the total subject population of this research. Neither has then examined the type of leadership style utilized nor sought to discover any statistically significant correlations among personal or demographic variables.

Operational Definitions

1. President: The chief executive and operating officer of a Masters I institution of higher education.

2. No-style: When no single leadership style is used by a president as determined by a score of less than 4.0 on Bolman and Deal's (1990) Leadership Orientation Instrument (Self). 
3. Single-style presidential leadership style: the one leadership style of the four possible frames: structural-frame, human resource-frame, political-frame and symbolic-frame used by a president as determined by a score equal to or greater than 4.0 on Bolman and Deal's (1990) Leadership Orientation Instrument (Self).

4. Paired-style presidential leadership style: the two leadership styles of the four possible frames: structural-frame, human resource-frame, political-frame and symbolic-frame used by a president as determined by a score equal to or greater than 4.0 on Bolman and Deal's (1990) Leadership Orientation Instrument (Self).

5. Multi-style presidential leadership style: at least three leadership styles of the four possible frames: structural frame, human resource frame, political frame and symbolic frame used by a president as determined by a score equal to or greater than 4.0 on Bolman and Deal's (1990) Leadership Orientation Instrument (Self).

6. All four frame presidential leadership style: the four leadership styles of the four possible frames: structural frame, human resource frame, political frame and symbolic frame used by a president as determined by a score equal to or greater than 4.0 on Bolman and Deal's (1990) Leadership Orientation Instrument (Self).

7. The Structural Frame: This frame concentrates of rules, formal roles and policies, authority and relationships. The use of organizational charts, formal 
rules and policies and management hierarchies are used to coordinate diverse activities.

8. The Human Resource Frame: This frame concentrates on the needs of the members of the organization. The task of the leader is to balance the needs of the members with the needs of the organization.

9. The Political Frame: This frame illuminates the constant struggle for power and resources in an institution where alliances, negotiations, and compromises are necessary occurrences.

10. The Symbolic Frame: This frame postulates that rituals, myths, ceremonies and heroes drive organizations, not by managerial authority or rules.

11. Masters I Institution: Institutions of higher education that award forty or more Masters degrees in a year across at least three fields. The institutions were defined by the Carnegie Classification system (2002)

12. First professional: Degrees awarded after completion of the academic requirements to begin practice in the following professions: Chiropractic (D.C or D.C. M.) Dentistry (D.D.S. or D. M. D), Law (L. L. B. or J. D.), Medicine (M.D.), Optometry (O.D), Osteopathic Medicine (D. O), Pharmacy (Pharm. D.), Podiatry (D.P.M.), D.P., or Pod. D), Theology (M. Div., M.H.L., B.D., or Ordination), and Veterinary Medicine (D.V.M) (NCES, 2002).

13. Headcount Enrollment: Headcount enrollment as of Fall 2001 as reported to the National Center for Education Statistics.

14. Geographic Location: The eight geographic locations as classified by the National Center for Education Statistics (see Appendix G). 
15. Type of Control. Public funded, Private- not for profit, and Private-for profit as categorized by the Carnegie Foundation (2001).

16. Community Population: Population of the community where the institution resides as determined by the United States Census Bureau (2000).

17. Status of Presidency: Respondents will report if this is an interim (temporary) presidency or a permanent presidency.

18. Number of Presidencies: Respondents will report if this presidency is their first, second or third or more presidency.

19. Last position held: Respondents will report their last position held before becoming president. The opens include: Academic Affairs, Student Affairs, Administration and Finance, Development, and Outside of Higher Education.

20. Age: Respondents will report their age category from the options of under 30, 30-39, 40-49, 50-59 and over 60 .

21. Race: Respondents will report if they are Caucasian, African-American, Hispanic, American Indian, Asian/Pacific Islander or Other.

22. Educational Degree: Respondents will report their highest educational degree earned from the options of Ph. D, Ed. D, M.D., Law, Masters, Bachelors, or Other.

23. Academic expertise: Respondents will report their academic background based on their highest educational degree earned from the options of Fine Arts/Humanities, Social Sciences, Physical/Natural Sciences, Medicine, Law, Education, Agriculture, and Religious Studies. 
24. Marital Status: Respondents will report their marital status from the options of never married, single, married, widow(er), or divorced.

25. Gender: Respondents will report if they are male or female.

26. Large City: An area defined by the United States Department of the Census as a metropolitan statistical areas (MSA) with a population greater than 250,000.

27. Mid Size City: An area defined by the United States Department of the Census as a (MSA) with a population less than 250,000 .

28. Urban Fringe of Large City: Any incorporated MSA of a Mid-size City and defined as urban by the Census Bureau.

29. Urban Fringe of Mid Size City: Any incorporated MSA of a Mid-size City and defined as urban by the Census Bureau.

30. Large Town: An incorporated place with a population greater than 25,000 as defined by the Census Bureau.

31. Small Town: An incorporated place with a population less than 25,000 and greater than 2,500 as defined by the Census Bureau.

32. Rural: An incorporated place with a population less than 2,500 as defined by the Census Bureau.

33. MANOVA: Multivariate analysis of variance is a procedure for testing the equality of mean vectors of more than two populations

34. ANOVA: Analysis of variance is a statistical test for heterogeneity of means by analysis of group variances.

35. Cronbach's alpha: A measurement of how well a set of items references a single unidimensional variable. It is a coefficient of reliability or consistency. 


\section{CHAPTER 3}

Method

\section{Research Design}

The purpose of this quantitative study is to identify the leadership frame(s) of Masters I institution presidents. Then, independent personal and institutional variables will be examined to determine if there are any significant differences between key variables and the leadership frames(s).

Survey research allows the research to draw inferences about the total population (Fraenkel and Wallen, 2000). However, since the total population is relatively small (494) the entire population was surveyed to minimize sampling errors.

This survey asked presidents of Masters I institutions to report the leadership styles that they predominantly utilize and demographic information. Institutional data was obtained from the National Center for Education Statistics.

The data was solicited by way of a mailed survey simultaneously to all potential participants. If after three weeks, the returns were below $50 \%$, a reminder notification was sent to participants who have not responded. If after another three weeks, and returns were below $50 \%$, a final reminder was sent. West Virginia University IRB approval was obtained before conducting the mailing and respondents' anonymity were protected.

Since each of these questions is discreet and non-overlapping, a quantitative research approach is appropriate. A questionnaire containing items addressing leadership frames and demographic variables were administered, by mail, to all presidents of Masters I institutions. Each respondent was presented with exactly the same instructions to ensure continuity and eliminate the chance of bias. The list for Masters I presidents was found in the 2003 Higher 
Education Directory. Each institution was assigned a three-digit identifier number that was placed on the survey. The population for this study was comprised of 494 presidents of Masters I institutions as determined by the Carnegie Foundation (2001).

All participants answered questions and provided demographic information about the institution and personal characteristics and demographic information about themselves. This information was used when analyzing the data to better understand the composition of Masters I presidents and to determine if there are any significant differences among a number of independent variables.

\section{Data Collection and Instrumentation}

Data was collected in 2003 through the use of Bolman and Deal's (1990) Leadership Orientations (Self). One of the authors, Dr. Lee Bolman, granted permission for the use of the Leadership Orientations (Self) instrument (see Appendix A). Additional questions concerning the presidential demographics and personal characteristics were developed by this researcher and included in the final section of the survey instrument (see Appendix B). Institutional demographic data such as location, type of control, community population, and enrollment were obtained independently from the survey by means of the Carnegie Classification database and the National Center for Education Statistics.

The survey instrument consists of four sections: (I) Behaviors, (II) Leadership Styles, (III) Overall Rating, and (IV) Demographics.

Section I, Behaviors, asked participants to rank on a Likert-like scale the frequency of certain behaviors. The responses range from 1 (never) to 5 (always). 
Section II, Leadership Styles, asked the participants to force choice their responses to describe their leadership style by rating from 1 to 4 the phrases that best describe them. A rating of 4 best describes the behavior, and a rating of 1 least describes the behavior.

Section III, Overall Rating, requested participants to rate themselves as a manager and as a leader. The rating is on a 1 to 5 scale with 1 representing the bottom $20 \%, 3$ the middle $20 \%$, and 5 representing the top $20 \%$.

Finally, Section IV, Demographics, sought individual personal and professional data from the presidents.

A cover letter (see Appendix C) was included with the survey instrument and mailed to 494 presidents. A follow-up letter (see Appendix D) and questionnaire was mailed to each president who did not responded within three weeks. Survey Instrument

Permission was granted by Dr. Lee Bolman to use the Bolman and Deal (1990) Leadership Orientations (Self) instrument. The approval letter appears in Appendix B. The questionnaire is based on the premise that the behaviors of leaders were a reflection of their conceptual orientations and representative patterns would emerge.

Bolman and Deal (1991) contend:

This is no perfect way to measure thinking; perceptual measures of how leaders behave provide only indirect evidence of how they frame experience. Essentially, researchers have two options: (a) ask people how they think, or (b) study how they perform on tasks that should reflect their thinking. The first method is problematic because people often do not know the theories they use 
(Weick, 1979) or may not know until after the fact (Argyris, 1972). Studying

performance is problematic because it requires that inferences be made about the thinking processes associated with performance (p. 514).

\section{Validity and Reliability}

Validity refers to the "defensibility of the inferences researchers make from the data collected through the use of an instrument" and reliability of an instrument is "one that gives consistent results" (Fraenkel \& Wallen, 2000, p. 128).

According to Bolman and Deal, (1991) the internal reliability of the instrument is very high. A high Cronbach's alpha for the frame measures attests to a strong internal consistency of like items for a particular rating. Bolman and Deal grant permission to use their survey for researcher use. On-going research by the authors and others support the validity and reliability claims of the instrument.

Dr. Lee Bolman analyzed and presented the additional data which supports the high internal reliability of the instrument. The Structural Frame, based on 1,309 colleague ratings from a multisector sample of managers in business and education yields a Cronbach's alpha of .920. The Human Resources Frame based on 1,331 colleague ratings from a multisector sample of managers in business and education yields a Cronbach's alpha of .931. The Political Frame based on 1,268 colleague ratings from a multisector sample of managers in business and education yields a Cronbach's alpha of .913. The Symbolic Frame based on 1,315 colleague ratings from a multisector sample of managers in business and education yields a Cronbach's alpha of .931 (Bolman, 2003, http://www.bsbpa.umkc.edu/classes/bolman/new_page_1.htm) 


\section{Strengths of the Design}

Survey research allows the data to be readily converted into quantitative information. The Leadership Orientations (Self) survey was sent to each potential participant requesting his or her assistance and asking that the survey be returned by a specified date. Mail surveys are a costeffective method since only minor costs for paper; envelopes and destination and return postage are required. Although time consuming, this procedure can be accomplished by the researcher working alone and not be bound by time or geographic boundaries due to the flat rate and distribution of the United States Postal System. Probably the greatest advantage to using a mailed survey is the time it allows participants to respond. Each participant can allocate the time of their choosing to respond to their survey (Fraenkel \& Wallen, 2000).

Although this method of research is common and attractive, disadvantages do exist. The survey may be quickly discarded since surveys from numerous sources are regularly received in higher education. Further, Masters I presidents are extremely busy individuals and they may not have the time, or choose to take the time, to respond to a survey from an unknown researcher. Finally, since the survey is self-reported, will presidents indicate the leadership styles they practice, or the styles they aspire to practice?

The survey procedure must be conducted under rigorous scrutiny by the researcher to ensure the validity of the data. Finally, the survey is worthless without participation and return of the survey to the researcher (Fraenkel \& Wallen, 2000).

\section{Limitations of the study}

1. Leadership style was measured as a self-perception and the study was limited by the accuracy of those perceptions (Kerlinger, 1986) 
2. The reliability and validity of the leadership style instrument, Bolman and Deal's (1990) Leadership Orientation Instrument (Self) imposed a limitation on the results of the study (Kerlinger, 1986).

3. Data from this study was from presidents of Masters I institutions and may not be generalized to other institutions (Kerlinger, 1986).

\section{Assumptions}

1. Survey participants provide honest responses to the survey instrument.

2. Survey participants and the researcher have the same understanding of terminology utilized in the survey instrument.

3. The survey instrument utilized for this research was appropriate to obtain the respondents self-rating of leadership orientation.

4. Responses to the instrument provide accurate data regarding the utilization of the four Bolman and Deal frames by Masters I presidents.

\section{Site Selection}

All presidents of Masters I institutions as identified by the Carnegie Classification were surveyed. Before mailing the questionnaires, a database was created which coded each institution. Preliminary data such as the state, geographic region, enrollment, type of control and community population was obtained from the National Center for Education Statistics. Since the total population numbers 494 institutions, a representative sample of 216 would be needed to achieve a $+/-5 \%$ margin of error, $95 \%$ of the time. However, since this population is relatively small, the entire population was surveyed. This survey of the total population could reduce the margin of error to less than one, approaching zero, $99 \%$ of the time. 


\section{Data Analysis}

Raw data was entered into a Microsoft Excel worksheet. Each institution had an individual row. Each column represented a survey question, and the institutional and personal demographic variables. The reported leadership styles and their combinations were crossed with the institutional and personal demographic responses. Descriptive statistics were computed and summarized in a data table for each variable. Frequencies and column and row percentages were presented. Cell percentages were not presented unless they were significant to the findings.

The data from the Excel worksheet was exported into SPSS for Windows for statistical analysis. An alpha level of .05 is the criterion level of significance for this study, and .01 and .001 levels were reported as well. If a variable's data yields a reasonable split, then a multivariate analysis of variance (MANOVA) was calculated. A reasonable split occurs when three or more possible responses have a maximum variance of 35\%. If the MANOVA was significant, an analyses of variances (ANOVAs) was conducted, one for each dependent variable in the MANOVA. If the number of respondents between groups were split according to this procedure, the split would be considered reasonable. As long as groups were within $35 \%$ of the frequency of each other, they were used as an identified variable, if not, descriptive statistics would suffice.

The first section of the Leadership Orientations (Self) survey, the mean scores, percentages and frequencies of the responses was calculated and sorted by frames. Table 6 was constructed by the researcher from the Bolman and Deal (1990) Leadership Orientations (Self) instrument to identify the eight questions that comprise each of the four leadership frames. 
Table 6

Bolman and Deal Survey Questions Associated with Each Frame

Structural Frame

1. Think very clearly and logically

5. Strongly emphasize careful planning and clear time lines

9. Approach problems through logical analysis and careful thinking

13. Develop and implement clear, logical policies and procedures

17. Approach problems with facts and logic

21. Set specific, measurable goals and hold people accountable for results

25. Have extraordinary attention to detail

29. Strongly believe in clear structure and a chain of command

Human Resource Frame

2. Show high levels of support and concern for others

6. Build trust through open and collaborative relationships

10. Show high sensitivity and concern for others' needs and feelings

14. Foster high levels of participation and involvement in decisions

18. Am consistently helpful and responsive to others

22. Listen well and am unusually receptive to other people's ideas and input

26. Give personal recognition for work well done

30. Am a highly participative manager 
$\underline{\text { Bolman And Deal Survey Questions Associated with Each Frame }}$

Political Frame

3. Have exceptional ability to mobilize people and resources to get things done

7. Am a very skillful and shrewd negotiator

11. Am unusually persuasive and influential

15. Anticipate and deal adroitly with organizational conflict

19. Am very effecting in getting support from people with influence and power

23. Am politically very sensitive and skillful

27. Develop alliances to build a strong base of support

31. Succeed in the face of conflict and opposition

Symbolic Frame

4. Inspire others to do their best

8. Am highly charismatic

12. Am able to be an inspiration to others

16. Highly imaginative and creative

20. Communicate a strong and challenging sense of vision and mission

24. See beyond current realities to generate exciting new opportunities

28. Generate loyalty and enthusiasm

32. Serve as an influential model of organizational aspirations and values 


\section{Research Questions}

1. Do presidents of Masters I institutions predominantly utilize, no-style, single-style, paired-style, or multi-style leadership?

The responses from participants who completed the Bolman and Deal's (1990) Leadership Orientations (Self) instrument would provide the database for answering this question. The mean and standard deviation for each frame was calculated. Then, the mean of each leadership frame was determined individually. A minimum score of 8 and a maximum score of 40 is possible. Respondents responses averaging 4.0 or above would be considered to utilize that frame. The overall mean, standard deviation by the four frames, and the number of the respondents who attest to using each frame would be reported. Frequencies and percentages of presidents who utilize different the patterns of none, single, paired, and multi-frame, along with different frame combination would also be identified and presented.

2. Is there a statistically significant difference in leadership style that is affected by institutional variables such as size of institution, geographic location, community population, and type of control (Appendices F, G, H)?

Bolman and Deal's (1990) Leadership Orientations (Self) and the demographic data outlined in Appendix F, G, H obtained from the Carnegie Foundation and the National Center for Education Statistics were used to answer this question. The respondents were grouped by the institutional variables of institutional size, geographic location, community population, and type of control. The frequency and percentage of presidents who use no, single, paired, or multiframe will be identified and reported by different sub-groups within each group and presented in a tabular format with column and row percentages for each variable. If a variables data yielded a reasonable split, then a multivariate analysis of variance (MANOVA) was calculated. If the 
MANOVA was significant, an analyses of variance (ANOVAs) was conducted, one for each dependent variable in the MANOVA. The splits had variance no greater than $35 \%$. If the number of respondents between groups were split according to this procedure, the split would be considered reasonable. As long as groups were within $35 \%$ of the frequency of each other, they would be used as an identified variable, if not, descriptive statistics would suffice. For example, if there were four possible responses, and the response distribution was $60 \%, 20 \%, 15 \%$ and $5 \%$ then a reasonable split has not occurred.

3. Is there a statistically significant difference in leadership style that is affected by personal characteristics such as gender, race, age, marital status, educational background, and last position held?

Bolman and Deal's (1990) Leadership Orientations (Self) and the Section IV Demographics were used to answer this question. The respondents were grouped by gender, race, age, marital status, educational background, and last position held. The frequency and percentage of presidents who used no, single, paired, or multi-frame were identified and reported by different sub-groups within each group. If a variables data yielded a reasonable split, then a MANOVA was calculated. If the MANOVA was significant, ANOVAs were conducted, one for each dependent variable in the MANOVA. The splits would have a variance no greater than $35 \%$. If the number of respondents between groups were split according to this procedure, the split would be considered reasonable. As long as groups were within $35 \%$ of the frequency of each other, they would be used as an identified variable, if not, descriptive statistics would suffice.

4. Is there a statistically significant difference in leadership style of individuals who are first time presidents and repeat presidents? 
Bolman and Deal's (1990) Leadership Orientations (Self) and the Section IV

Demographics were used to answer this question. The respondents were grouped interim presidents, first time presidents, second time presidents, and respondents who had three or more presidencies. The frequency and percentage of presidents who used no, single, paired, or multiframe were identified and reported by each group. If a variables data yielded a reasonable split, then a MANOVA was calculated. If the MANOVA was significant, ANOVAs were conducted, one for each dependent variable in the MANOVA.

5. Is there a statistically significant difference in leadership style of individuals who had less than one year of experience as a president, between one and five years of experience as a president, between six and ten years of experience as a president, between eleven and fifteen years of experience as a president, and more than fifteen years of experience as a president?

Bolman and Deal's (1990) Leadership Orientations (Self) and the Section IV Demographics were used to answer this question. The respondents were grouped by presidents who had less than one year of experience, between one and five years of experience, between six and ten years of experience as a present, between eleven and fifteen years experience as a president and those presidents who had more than fifteen years of experience. The frequency and percentage of presidents who used no, single, paired, or multi-frame were identified and reported by different sub-groups within each group. If a variables data yielded a reasonable split, then a MANOVA was calculated. If the MANOVA was significant, ANOVAs were conducted, one for each dependent variable in the MANOVA. The splits had a variance no greater than $35 \%$. If the number of respondents between groups was split according to this procedure, the split was considered reasonable. As long as groups are within $35 \%$ of the frequency of each other, they were used as an identified variable, if not, descriptive statistics would suffice. 


\section{Timeframe}

The researcher applied for Institutional Research Board (IRB) approval during the summer of 2003. The revised cover letter and questionnaire was mailed to the presidents of Masters I institutions during the summer of 2003. Follow-up reminders were sent three weeks after the initial solicitation and again after six weeks. The results of this study along with the findings and recommendations followed.

\section{Background of the Researcher}

The researched earned a Bachelor of Arts degree (1979) from Westminster College in New Wilmington, Pennsylvania. He worked in retail management and public administration for 17 years. He completed the requirements to earn a Masters of Business Administration (1991) from Frostburg State University in Frostburg, Maryland.

The researcher served for $7 \frac{1}{2}$ years as the Chief Financial Officer of Potomac State College of West Virginia University, a regional campus of West Virginia University and is currently teaching undergraduate and MBA Management and Leadership classes as a member of the Business and Management Faculty at Frostburg State University, a Masters I institution. He has completed the coursework and has passed the competency exams in the goal of receiving a doctoral degree in Educational Leadership from West Virginia University, Morgantown, West Virginia.

The researcher believes in the value that leadership has in any organization. The researcher feels that the finding in this study provides insight into the leadership styles utilized at Masters I Institutions. Presidents or prospective presidents at Masters I institutions can improve their leadership style by adopting a multiple frame perspective. 


\section{CHAPTER 4}

Results

This study examines the leadership styles of presidents at Master's level I institutions as defined by the Carnegie Foundation (2001). This chapter presents an analysis of the results obtained from the returned surveys concerning the leadership styles utilized by these presidents. The study examines the relationships between leadership style and demographic variables. Bolman and Deal devised a four-frame model that included the structural, human resource, political, and symbolic leadership frames. These frames, or windows, allow users to view the world and problems from various perspectives (Bolman \& Deal, 1984). Three predominant styles are deducible from the four frames: single-style, paired-style and multi-style leadership orientations. In cases where no discernable use of any frame occurs, the category of "no-frame" is used. In this study, the Bolman and Deal (1990) Leadership Orientations (Self) was used.

\section{Survey Responses and Demographic Background}

The entire population of 494 presidents at Masters I institutions as identified by the Carnegie Foundation (2001) were surveyed. The institutions were further subdivided by type of control, geographic location, community population, and enrollment. A total of 254 usable surveys were received yielding a return rate of 51.4 percent.

Nearly $77 \%$ of the respondent population was male. In addition, the majority $(86.6 \%)$ of presidents were Caucasian, and the majority (79.1\%) were married (see Table 7). In addition, approximately half of the presidents were under the age of $60(52.3 \%)$, and the remaining half was over the 60 years of age. 
Table 7

Demographic Profile of Presidents

\begin{tabular}{|c|c|c|}
\hline & \multicolumn{2}{|c|}{ Response } \\
\hline & $\mathrm{N}$ & $\%$ \\
\hline \multicolumn{3}{|l|}{ Gender } \\
\hline Female & 59 & 23.2 \\
\hline Male & 195 & 76.8 \\
\hline Total & 254 & 100.0 \\
\hline \multicolumn{3}{|l|}{ Age } \\
\hline Under 30 & 0 & 0.0 \\
\hline 30 to 39 & 0 & 0.0 \\
\hline 40 to 49 & 9 & 3.5 \\
\hline 50 to 59 & 124 & 48.8 \\
\hline Over 60 & 119 & 46.9 \\
\hline No Response & 2 & 0.8 \\
\hline Total & 254 & 100.0 \\
\hline \multicolumn{3}{|l|}{ Race } \\
\hline Caucasian & 220 & 86.6 \\
\hline African-American & 18 & 7.1 \\
\hline Hispanic & 10 & 3.9 \\
\hline American Indian & 2 & 0.8 \\
\hline Asian/Pacific Islander & 3 & 1.2 \\
\hline Other & 1 & 0.4 \\
\hline Total & 254 & 100.0 \\
\hline \multicolumn{3}{|l|}{ Marital Status } \\
\hline Never married & 32 & 12.6 \\
\hline Single & 8 & 3.1 \\
\hline Married & 201 & 79.1 \\
\hline Widowed & 4 & 1.6 \\
\hline Divorced & 8 & 3.1 \\
\hline No Response & 1 & 0.4 \\
\hline Total & 254 & 100.0 \\
\hline
\end{tabular}


Nearly all $(95.7 \%)$ of the respondents were permanent presidents. Ninety percent of the presidents had earned a doctoral degree. Nearly one-third of the presidents' academic expertise was in education and first-time presidents accounted for $70.5 \%$ of the respondents (see Table 8 ). 
Table 8

President Responses by Education and Career Variables

\begin{tabular}{|c|c|c|}
\hline & \multicolumn{2}{|c|}{ Response } \\
\hline & $\mathrm{N}$ & $\%$ \\
\hline \multicolumn{3}{|l|}{ Highest Degree } \\
\hline Bachelor & 0 & 0.0 \\
\hline Master & 17 & 6.7 \\
\hline Law & 5 & 2.0 \\
\hline Other & 4 & 1.6 \\
\hline \multicolumn{3}{|l|}{ Doctorate } \\
\hline Ed. D. & 41 & 16.1 \\
\hline Ph. D & 187 & 73.6 \\
\hline Total & 254 & 100.0 \\
\hline \multicolumn{3}{|l|}{ Academic Expertise } \\
\hline Fine Arts/Humanities & 45 & 17.7 \\
\hline Social Sciences & 70 & 27.6 \\
\hline Physical/Natural Sciences & 30 & 11.8 \\
\hline Medicine & 4 & 1.6 \\
\hline Law & 7 & 2.8 \\
\hline Education & 79 & 31.1 \\
\hline Agriculture & 0 & 0.0 \\
\hline Religious Studies & 15 & 5.9 \\
\hline No Response & 4 & 1.6 \\
\hline Total & 254 & 100.0 \\
\hline \multicolumn{3}{|l|}{ Presidency Status } \\
\hline Interim/Temporary & 11 & 4.3 \\
\hline Permanent & 243 & 95.7 \\
\hline Total & 254 & 100.0 \\
\hline \multicolumn{3}{|l|}{ Number of Presidencies } \\
\hline First presidency & 179 & 70.5 \\
\hline Second presidency & 51 & 20.1 \\
\hline Third or more presidency & 23 & 9.1 \\
\hline No Response & 1 & 0.4 \\
\hline Total & 254 & 100.0 \\
\hline
\end{tabular}


The largest group of respondents had been presidents between one and five years

(29.5\%). In addition, a prior position in academic affairs appeared with the greatest frequency (46.9\%) (see Table 9).

Table 9

President Responses by Demographic Variables

\begin{tabular}{lrr}
\hline & \multicolumn{2}{c}{ Responses } \\
& $\mathrm{N}$ & \multicolumn{1}{c}{$\%$} \\
\hline Length of Time as President & & \\
Less than 1 year & 75 & 29.5 \\
1 to 5 years & 69 & 27.2 \\
6 to 10 years & 37 & 14.6 \\
11-15 years & 64 & 25.2 \\
Over 15 years & 1 & 0.4 \\
No Response & 254 & 100.0 \\
Total & & \\
& & \\
Last position & 66 & 26.0 \\
President at another institution & 119 & 46.9 \\
Academic VP, Dean or Chair & 13 & 5.1 \\
Student Affairs & 14 & 5.5 \\
Administration and Finance & 13 & 5.1 \\
Development & 21 & 8.3 \\
Other Higher Ed (please specify) & & \\
Outside higher education (specify) & 4 & 1.6 \\
$\quad$ Business & 0 & 0.0 \\
Military & 2 & 0.8 \\
Clergy & 0 & 0.0 \\
Other & 2 & 0.8 \\
No Response & 254 & 100.0 \\
Total & & \\
& &
\end{tabular}


Presidents of public institutions represented $52.4 \%$ of the respondents and presidents of private institutions accounted for $47.6 \%$ of the population (see Table 10). Institutions with enrollments between 2,001 and 4,000 were the largest represented group (27.6\%) followed closely by institutions with enrollments between 6,001 and 10,000 (26.4\%). The Southeast contained the largest number of respondent institutions (25.2\%), and mid-size cities possessed the greatest concentration of institutions (32.3\%) (see Table 10). 
Table 10

$\underline{\text { President Responses by Institutional Variables }}$

\begin{tabular}{|c|c|c|}
\hline & \multicolumn{2}{|c|}{ Response } \\
\hline & $\mathrm{N}$ & $\%$ \\
\hline \multicolumn{3}{|l|}{ Type of Control } \\
\hline Public & 133 & 52.4 \\
\hline Private & 121 & 47.6 \\
\hline Total & 254 & 100.0 \\
\hline \multicolumn{3}{|l|}{ Institutional Enrollment } \\
\hline Under 2,000 & 38 & 15.0 \\
\hline $2,001-4,000$ & 70 & 27.6 \\
\hline $4,001-6,000$ & 48 & 18.9 \\
\hline $6,001-10,000$ & 67 & 26.4 \\
\hline Over 10,000 & 31 & 12.2 \\
\hline Total & 254 & 100.0 \\
\hline \multicolumn{3}{|l|}{ Geographic Location } \\
\hline New England & 15 & 5.9 \\
\hline Mid Atlantic & 45 & 17.7 \\
\hline Great Lakes & 42 & 16.5 \\
\hline Plains & 23 & 9.1 \\
\hline South East & 64 & 25.2 \\
\hline South West & 25 & 9.8 \\
\hline Rocky Mountains & 8 & 3.1 \\
\hline Far West & 32 & 12.6 \\
\hline Total & 254 & 100.0 \\
\hline \multicolumn{3}{|l|}{ Community Population } \\
\hline Large City & 46 & 18.1 \\
\hline Mid-Sized City & 82 & 32.3 \\
\hline Urban Fringe of Large City & 41 & 16.1 \\
\hline Urban Fringe of Mid-Sized City & 24 & 9.4 \\
\hline Large Town & 11 & 4.3 \\
\hline Small Town & 46 & 18.1 \\
\hline Rural & 4 & 1.6 \\
\hline Total & 254 & 100.0 \\
\hline
\end{tabular}




\section{Statistical Analysis of Data}

There are four possible leadership styles: single, paired, multi, and no-style. After a style emerged, the frame(s) were determined. The five major frames are the structural, human resources, political, symbolic and no-frame that can be used alone or in concert with other frames, leading to sixteen possible frame(s) combinations.

Participants utilized a Likert-like scale to record their behaviors. The responses ranged from 1 (never) to 5 (always). A mean score of 4.0 or greater on a scale of 1-5 indicating "often" or "always" was the criterion for assigning a leadership style to the respondents.

Descriptive statistics examined the frequency for each of the research questions. Likewise, A Chi-Square goodness of fit analysis was conducted for all the research questions to determine if significance differences occurred. For research questions three, four, and five, a multivariate analysis of variance (MANOVA) and an analysis of variance (ANOVA) were performed to determine differences between groups. Finally, a Pearson's Correlation was performed to determine if statistically significant relationships existed between the leadership style and the research variables in question three, four, and five. An alpha level of .05 was used as the criterion to establish significance.

\section{Major Findings}

This section presents the findings as derived from an analysis of the data. The five research questions that guided this study provided the framework for reporting the results of the leadership styles and frames of Masters I presidents.

Research Question One. Do presidents of Masters I institutions predominantly utilize nostyle, a single style of leadership, a paired style of leadership, or multiple styles of leadership? 
In order to answer the first research question it was necessary to determine the means for each of the four frames. The mean responses for all four-frame styles were consistently high. The results ranged from a low of 3.842 for the political frame to a high of 4.149 for the human resources frame (see Table 11). Similarly, the standard deviations were calculated and revealed both modest and consistent results as the standard deviations ranged from a low of .482 for the human resources frame to a high of .550 for the symbolic frame. This analysis demonstrates that with few exceptions, respondents consistently rated their behavior on the Likert scale questionnaire as 4 “often”, or 5 “always" (see Table 11).

Table 11

Mean and Standard Deviation of Section I

Frame Mean $\quad$ Standard Deviation

$\begin{array}{lll}\text { Structural } & 3.988 & 0.488\end{array}$

$\begin{array}{lll}\text { Human Resources } & 4.149 & 0.482\end{array}$

$\begin{array}{lll}\text { Political } & 3.842 & 0.530\end{array}$

$\begin{array}{lll}\text { Symbolic } & 3.946 & 0.550\end{array}$

The results of the means were tabulated and arranged by leadership styles based on the criterion mean of 4.0 or greater (see Table 12). The respondents reported using the multi-frame leadership style most frequently (43.7\%) and the no-frame approach the least frequently (13.0\%). The results for the paired style and single style were virtually identical $(22.4 \%)$ and (20.9\%) respectively.

As a further analysis of research question one, it was found that not only was the multistyle used more frequently, but also the usage was statistically significant. A one-way Chi- 
Square test was performed, and the critical value of 7.82 was exceeded. This finding signals a significant difference at the .05 level, $\chi^{2}(3, n=254)=13.17, p<.05$ pointing to the significant frequency of the multi-frame style.

Table 12

Leadership Frames Utilized

\begin{tabular}{lccc} 
Frame Utilized & $\mathrm{N}$ & $\%$ & $\chi^{2}$ \\
\hline No-frame & 33 & $13.0 \%$ & \\
Single-frame & 53 & $20.9 \%$ & \\
Paired-Frame & 57 & $22.4 \%$ & \\
Multi-Frame & 111 & $43.7 \%$ & \\
Total & 254 & $100.0 \%$ & \\
${ }^{*} p<.05$ & &
\end{tabular}

Within the multi-frame style, the four-frame approach accounted for over $26 \%$ of the responses and the three-frame approach over $17 \%$ of the responses (see Table 13). Within the paired-frame style, the structural-human resources-frame was used most frequently, $(10.2 \%)$; and within the single-framed style, the human resource-frame was the most utilized $(12.6 \%)$. 
Table 13

Frequency Distribution by Style and Frame

\begin{tabular}{lrr}
\hline Style & $\mathrm{N}$ & $\%$ \\
& & \\
\hline & & \\
No-frame & 33 & 13.0 \\
& & \\
Single-frame & & \\
Structural & 11 & 4.3 \\
Human Resource & 32 & 12.6 \\
Political & 4 & 1.6 \\
Symbolic & 6 & 2.4 \\
Total & 53 & 20.9 \\
& & \\
Paired-frame & & \\
Structural-Human Resource & 26 & 10.2 \\
Structural-Political & 1 & 0.4 \\
Structure-Symbolic & 1 & 0.4 \\
Human Resource-Political & 6 & 2.4 \\
Human Resource-Symbolic & 18 & 7.1 \\
Political-Symbolic & 5 & 2.0 \\
Total & 57 & 22.4
\end{tabular}

Multi-frame

Structural-Human Resource-Political

Structural-Human Resource-Symbolic

6
14

Structural-Political-Symbolic

$14 \quad 5.5$

Human Resource-Political-Symbolic

$9 \quad 3.5$

Four-frame

$15 \quad 5.9$

Total

$67 \quad 26.4$

$111 \quad 43.7$


Consistent with the Bolman and Deal leadership research approach, this study also identified the frequency with which specific leadership frames (as opposed to styles) were selected by the respondents.

The 254 respondents in this study utilized a total of 600 frames. The human resourcesframe was most frequently employed (30.7\%) and the no-frame was the least utilized (5.5\%)(see Table 14)

A Chi-Square test determined that it was statistically significant. This test revealed that the critical value of 9.49 was greatly exceeded. A significant difference was found at the .01 level, $\chi^{2}(4, \mathrm{n}=600)=101.37, p<.01$. This finding points to the higher usage of the human resources-frame and the lower than expected usage of the no-frame.

Table 14

Leadership Frame Utilized Alone or in Concert

\begin{tabular}{lccc} 
& $\mathrm{N}$ & $\%$ & $\chi^{2}$ \\
\hline No-frame & 33 & 5.5 & $101.37^{* *}$ \\
Structural & 135 & 22.5 & \\
Human Resource & 184 & 30.7 & \\
Political & 113 & 18.8 \\
Symbolic & 135 & 22.5 & \\
Total & 600 & 100.0 \\
& &
\end{tabular}


Research Question Two. Is there a statistically significant difference in leadership style that is affected by institutional variables such as size of institution, geographic location, community population, and type of control (Appendices F, G, H)?

Descriptive statistics were used to categorize the style usage by the institutional variables. Then, a Chi-Square goodness of fit test was performed to determine if statistically significant differences occurred. A Pearson's correlation was performed on the type of control variable to ascertain if a statistically significant relationship existed.

\section{Institutional Enrollments}

Descriptive statistics were used to categorize the style usage by the institutional variables. Then, a Chi-Square goodness of fit test was performed to determine if statistically significant differences occurred. Institutional enrollments were divided into five categories and the findings are presented in Table 15. The first important finding indicated that the multi-frame style most frequently appeared in institutions of all enrollment sizes. Secondly, a noticeable ratio (29.0\%) of single-frame presidents appeared at institutions with the largest enrollment, and no-frame style was utilized (32.9\%) more in institutions with less than 4,000 students, and was evenly split (10.4\%)in institutions with more than 4,000 students. A Chi-Square analysis was conducted and found the distribution not significant at the .05 level, $\chi^{2}(12, \mathrm{n}=254)=13.84, p>.05$. The critical value for this grouping was 21.03 .

Although presidents of institutions of all sizes employed the multi-frame style preeminently, presidents of institutions with enrollments over 10,000 utilized this style most frequently (54.8\%); however presidents of institutions with enrollments between 2,000 and 4,000 utilized it less frequently (37.1\%). Presidents of institutions with enrollments between 4,000 and 
6,000 exhibited the paired-style $(33.3 \%)$ of human resource-symbolic-frames more than any of their counterparts (see Table 15).

\section{Geographic Location}

Descriptive statistics were used to categorize the style usage by the institutional variables. Then, a Chi-Square goodness of fit test was performed to determine if statistically significant differences occurred. The presidents predominantly utilized multi-frame style in all eight geographic regions, and most frequently in the Northeast (53.3\%). The paired-frame style appeared second highest in five out of eight regions. The single-frame style was the second highest utilized style in the Northeast, Great Lakes, Rocky Mountains, and Far West regions. The no-frame style appeared higher than average in the Mid-Atlantic, Great Lakes, Southeast, and Rocky Mountains (see Table 15).

A Chi-Square analysis was conducted and found no significant relationship between the leadership styles and geographic location at the .05 level, $\chi^{2}(21, \mathrm{n}=254)=18.60, p>.05$. In order for a significant relationship to occur, the Chi-Square result would need to exceed the critical value of 32.7. No significant relationships emerged from this grouping testifying to the fact that leadership style has no bearing on the geographical location of the institution. 
Table 15

Distribution Among Enrollment and Location

\begin{tabular}{|c|c|c|c|c|c|c|c|c|c|}
\hline & \multicolumn{2}{|l|}{ No } & \multicolumn{2}{|c|}{ Single } & \multicolumn{2}{|c|}{ Paired } & \multicolumn{2}{|c|}{ Multiple } & \multirow[b]{2}{*}{$\chi^{2}$} \\
\hline & $\mathrm{N}$ & $\%$ & $\mathrm{~N}$ & $\%$ & $\mathrm{~N}$ & $\%$ & $\mathrm{~N}$ & $\%$ & \\
\hline Enrollment $(\mathrm{n}=254)$ & & & & & & & & & 13.84 \\
\hline Under 2,000 $(\mathrm{n}=38)$ & 6 & 15.8 & 9 & 23.7 & 7 & 18.4 & 16 & 42.1 & \\
\hline $2,001-4,000(n=70)$ & 12 & 17.1 & 15 & 21.4 & 17 & 24.3 & 26 & 37.1 & \\
\hline $4,001-6,000(n=48)$ & 5 & 10.4 & 5 & 10.4 & 16 & 33.3 & 22 & 45.8 & \\
\hline $6,001-10,000(n=67)$ & 7 & 10.4 & 15 & 22.4 & 15 & 22.4 & 30 & 44.8 & \\
\hline Over $10,000(n=31)$ & 3 & 9.7 & 9 & 29.0 & 2 & 6.5 & 17 & 54.8 & \\
\hline Geographic Location $(\mathrm{n}=254)$ & & & & & & & & & 18.60 \\
\hline New England $(\mathrm{n}=15)$ & 1 & 6.7 & 3 & 20.0 & 3 & 20.0 & 8 & 53.3 & \\
\hline Mid Atlantic $(n=45)$ & 7 & 15.6 & 6 & 13.3 & 12 & 26.7 & 20 & 44.4 & \\
\hline Great Lakes $(n=42)$ & 7 & 16.7 & 12 & 28.6 & 9 & 21.4 & 14 & 33.3 & \\
\hline Plains $(n=23)$ & 1 & 4.3 & 4 & 17.4 & 9 & 39.1 & 9 & 39.1 & \\
\hline Southeast $(n=64)$ & 11 & 17.2 & 12 & 18.8 & 13 & 20.3 & 28 & 43.8 & \\
\hline Southwest $(n=25)$ & 2 & 8.0 & 5 & 20.0 & 7 & 28.0 & 11 & 44.0 & \\
\hline Rocky Mountains $(\mathrm{n}=8)$ & 2 & 25.0 & 2 & 25.0 & 1 & 12.5 & 3 & 37.5 & \\
\hline Far West $(\mathrm{n}=32)$ & 2 & 6.3 & 9 & 28.2 & 3 & 9.4 & 18 & 56.3 & \\
\hline
\end{tabular}

\section{Community Population}

Descriptive statistics were used to categorize the style usage by the institutional variables.

Then, a Chi-Square goodness of fit test was performed to determine if statistically significant differences occurred. The presidents in six of the eight community population categories predominately utilized the multi-frame leadership style. However, the rural areas were the lone exception since they favored a no-frame style (50.0\%). The paired-style was the second most utilized style in three of the community population categories; however the single-frame style was the second most utilized style in four out of eight categories. Presidents who used the noframe style resided in six out of seven community population categories (see Table 16). 
A Chi-Square analysis was conducted and found no significant relationship between the leadership frames utilized and the community population at the .05 level, $\chi^{2}(18, n=254)=19.67$, $p>.05$. This result did not exceed the critical value of 28.9 for significance.

\section{Type of Control}

Descriptive statistics were used to categorize the style usage by the institutional variables. Then, a Chi-Square goodness of fit test was performed to determine if statistically significant differences occurred. A Pearson's correlation was performed on the type of control variable to ascertain if a statistically significant relationship existed. The presidents primarily utilized the multi-frame leadership style predominant regardless of the type of control. However, presidents of public institutions utilized the multi-frame style $7 \%$ more frequently than presidents of private institutions (see Table 16). Conversely, presidents of private institutions utilized paired leadership as the second highest style $6 \%$ more than presidents of public institutions. The pairedframe human resource-symbolic was employed 7\% more in private institutions; however the structural-human resource-frame was utilized $6 \%$ more frequently in public institutions. The single-frame of human resources was practiced $7 \%$ more in public institutions than in private institutions (see Table 16).

Tests of statistical significance did not reveal any relationships. A Chi-Square analysis was conducted and found no significant relationships between leadership style and institutional control at the .05 level, $\chi^{2}(3, \mathrm{n}=254)=1.95, p>.05$. The critical value for significance was 7.82 . A Pearson's correlation coefficient was calculated and did not find a statistically significant relationship between leadership style and type of control, $r=-.042, n=254, p>.05$. 
Table 16

Distribution Among Population and Control

\begin{tabular}{cccccccccc} 
No & \multicolumn{1}{c}{ Single } & \multicolumn{1}{c}{ Paired } & Multiple \\
\hline $\mathrm{N}$ & $\%$ & $\mathrm{~N}$ & $\%$ & $\mathrm{~N}$ & $\%$ & $\mathrm{~N}$ & $\%$ & $\chi^{2}$ & $r$ \\
\hline
\end{tabular}

Community Population $(\mathrm{n}=254)$

Large City $(\mathrm{n}=46)$

Mid-sized City $(\mathrm{n}=82)$

$\begin{array}{llllllll}6 & 13.0 & 12 & 26.1 & 6 & 13.0 & 22 & 47.8\end{array}$

$\begin{array}{llllllll}9 & 11.0 & 15 & 18.3 & 26 & 31.7 & 32 & 39.0\end{array}$

Urban Fringe of Large City $(n=41)$

$\begin{array}{lllllllll}5 & 12.2 & 8 & 19.5 & 7 & 17.1 & 21 & 51.2\end{array}$

Urban Fringe of Mid-Sized City $(\mathrm{n}=24)$

Large Town $(\mathrm{n}=11)$

$\begin{array}{llllllll}2 & 8.3 & 4 & 16.7 & 3 & 12.5 & 15 & 62.5\end{array}$

Small Town $(\mathrm{n}=46)$

$\begin{array}{llllllll}1 & 9.1 & 2 & 18.2 & 3 & 27.3 & 5 & 45.5\end{array}$

Rural $(\mathrm{n}=4)$

$\begin{array}{rrrrrrrr}8 & 17.4 & 12 & 26.1 & 11 & 23.9 & 15 & 32.6\end{array}$

$\begin{array}{llllllll}2 & 50.0 & 0 & 0.0 & 1 & 25.0 & 1 & 25.0\end{array}$

Type of Control $(\mathrm{n}=254)$

9.67

Public $(\mathrm{n}=133)$

$\begin{array}{llllllll}17 & 12.8 & 27 & 20.3 & 26 & 19.5 & 63 & 47.4\end{array}$

Private $(\mathrm{n}=121)$

$\begin{array}{llllllll}16 & 13.2 & 26 & 21.5 & 31 & 25.6 & 48 & 39.7\end{array}$

$\begin{array}{ll}1.95 & -.042\end{array}$ 
Research Question Three. Is there a statistically significant difference in leadership style that is affected by personal characteristics such as gender, race, age, marital status, educational background, and last position held?

\section{Gender}

The initial analysis focused on descriptive statistics to examine the demographic variables. Then a Chi-Square goodness of fit test was performed to determine if statistically significant differences occurred. If the variable had more than two discreet components the variables were then reformatted to obtain a dummy variable. This modified variable could then undergo a Pearson's correlation to determine if a statistically significant relationship existed. Even though nearly $77 \%$ of the respondents were male, both female and male presidents employed the multi-frame leadership style most frequently; however females utilized the multiframe style more often $(7.1 \%)$. The paired-style was the second most utilized style for males $(24.6 \%)$, however the single-frame style was the second most practiced style by females (23.7\%). Both female and male presidents least utilized the no-frame leadership style (see Table 17).

Females employed the structural-frame more often than males (7.6\%); however males endorsed the human resource-frame more often than females (5.3\%). Males also utilized the paired structural-human resource-frame most often $(8.9 \%)$ (see Table 17$)$.

Tests of statistical significance did not reveal any relationships. A Chi-Square analysis was conducted and found that there was no significant relationship between leadership styles and gender at the .05 level, $\chi^{2}(3, \mathrm{n}=254)=2.67, p>.05$. This distribution must exceed the critical value 7.82 for significance. A Pearson's correlation coefficient was calculated and found no 
statistically significant relationship between leadership style and gender, $r=-.002, \mathrm{n}=254$, $p>.05$.

Table 17

Leadership Styles and Frames by Gender

\begin{tabular}{lcrrr} 
Frame Utilized & Female & $\%$ & Male & $\%$ \\
\hline No-frame & & & & \\
& 7 & 11.9 & 26 & 13.3 \\
Single-frame & & & & \\
$\quad$ Structural & 6 & 10.2 & 5 & 2.6 \\
$\quad$ Human Resource & 5 & 8.5 & 27 & 13.8 \\
Political & 1 & 1.7 & 3 & 1.5 \\
$\quad$ Symbolic & 2 & 3.4 & 4 & 2.1 \\
Total & 14 & 23.7 & 39 & 20.0
\end{tabular}

Paired-frame

Structural-Human Resource

Structural-Political

Structure-Symbolic

Human Resource-Political

Human Resource-Symbolic

Political-Symbolic

Total

$\begin{array}{rrrr}2 & 3.4 & 24 & 12.3 \\ 0 & 0.0 & 1 & 0.5 \\ 0 & 0.0 & 1 & 0.5 \\ 1 & 1.7 & 5 & 2.6 \\ 5 & 8.5 & 13 & 6.7 \\ 1 & 1.7 & 4 & 2.1 \\ 9 & 15.3 & 48 & 24.6\end{array}$

Multi-Frame

$\begin{array}{lllll}\text { Structural-Human Resource-Political } & 2 & 3.4 & 4 & 2.1\end{array}$

$\begin{array}{lllll}\text { Structural-Human Resource-Symbolic } & 4 & 6.8 & 10 & 5.1\end{array}$

$\begin{array}{lllll}\text { Structural-Political-Symbolic } & 1 & 1.7 & 8 & 4.1\end{array}$

Human Resources-Political-Symbolic $\begin{array}{lllll}4 & 6.8 & 11 & 5.6\end{array}$

$\begin{array}{lllll}\text { Four-frame } & 18 & 30.5 & 49 & 25.1\end{array}$

$\begin{array}{lllll}\text { Total } & 29 & 49.2 & 82 & 42.1\end{array}$


Race

The initial analysis focused on descriptive statistics to examine the styles and frames by race. Then, a Chi-Square goodness of fit test was performed to determine if statistically significant differences occurred. The variables were then reformatted into two options so that this dummy variable could undergo a Pearson's correlation to determine if a statistically significant relationship existed. Caucasians accounted for most of the respondents (86.6\%). AfricanAmerican presidents were the largest minority (7.1\%), followed by Hispanic (3.95), and Asian (1.2\%). There were no Native American presidents. The 34 non-Caucasian respondents represented five races. Due to this small size of minority presidents, the data was aggregated by comparing Caucasian and non-Caucasian presidents. Although both Caucasian's and nonCaucasian presidents most cited the multi-frame leadership style, non-Caucasian presidents employed this style more often (20.9\%). Both groups equally employed the paired-frame style, however, Caucasian presidents more often utilized the single and no-frame style (see Table 18).

Tests of statistical significance did not reveal any relationships. A Chi-Square analysis was conducted and found no significant relationship between leadership styles and race at the .05 level, $\chi^{2}(3, \mathrm{n}=254)=6.08, p>.05$. Since this finding did not surpass the critical value of 7.82 , significance did not result. Since the data was aggregated, it was possible to perform a Pearson's correlation coefficient. Unfortunately, there was no statistically significant relationship between leadership style and race at the .05 level, $\mathrm{r}=+.053, \mathrm{n}=254, \mathrm{p}>.05$.

Overall, Caucasian presidents utilized the no-frame, single-frame, and paired-frame leadership styles more frequently than Non-Caucasian presidents. However, the paired human resources-symbolic-frame and the political-symbolic-frame were the exceptions as Caucasian presidents utilized these specific styles fewer than Non-Caucasian presidents (see Table 18). 
Table 18

Leadership Styles and Frames by Race

\begin{tabular}{|c|c|c|c|c|c|c|}
\hline Frame Utilized & Caucasian & $\%$ & Non-Caucasian & $\%$ & $\chi^{2}$ & $r$ \\
\hline & & & & & 6.08 & +.053 \\
\hline No-frame & 31 & 14.1 & 2 & 5.9 & & \\
\hline \multicolumn{7}{|l|}{ Single-frame } \\
\hline Structural & 10 & 4.5 & 1 & 2.9 & & \\
\hline Human Resource & 30 & 13.6 & 2 & 5.9 & & \\
\hline Political & 4 & 1.8 & 0 & 0.0 & & \\
\hline Symbolic & 5 & 2.3 & 1 & 2.9 & & \\
\hline Total & 49 & 22.3 & 4 & 11.8 & & \\
\hline \multicolumn{7}{|l|}{ Paired-frame } \\
\hline Structural-Human Resource & 21 & 9.5 & 5 & 14.7 & & \\
\hline Structural-Political & 1 & 0.5 & 0 & 0.0 & & \\
\hline Structure-Symbolic & 0 & 0.0 & 1 & 2.9 & & \\
\hline Human Resource-Political & 5 & 2.3 & 1 & 2.9 & & \\
\hline Human Resource-Symbolic & 18 & 8.2 & 0 & 0.0 & & \\
\hline Political-Symbolic & 5 & 2.3 & 0 & 0.0 & & \\
\hline Total & 50 & 22.7 & 7 & 20.6 & & \\
\hline \multicolumn{7}{|l|}{ Multi-frame } \\
\hline Structural-Human Resource-Political & 5 & 2.3 & 1 & 2.9 & & \\
\hline Structural-Human Resource-Symbolic & 13 & 5.9 & 1 & 2.9 & & \\
\hline Structural-Political-Symbolic & 8 & 3.6 & 1 & 2.9 & & \\
\hline Human Resources-Political-Symbolic & 13 & 5.9 & 2 & 5.9 & & \\
\hline Four-frame & 51 & 23.2 & 16 & 47.1 & & \\
\hline Total & 90 & 40.9 & 21 & 61.8 & & \\
\hline
\end{tabular}


Age

The initial analysis focused on descriptive statistics to examine the styles and frames by age. Then, a Chi-Square goodness of fit test was performed to determine if statistically significant differences occurred. The variables were then reformatted into two options so that this dummy variable could undergo a Pearson's correlation to determine if a statistically significant relationship existed. There were no Masters I presidents under the age of forty; however over half of the presidents were under the age of 60 (52.3\%). These presidents tended to use the multiframe style (46.6\%) and the paired-style more frequently (24.1) than presidents over the age of $60,5.4 \%$ and $3.9 \%$ respectively. Presidents over the age of 60 tended to employ a singe-frame style $(23.5 \%)$ and a no-frame style more often (15.1\%) than their peers (see Table 19). However, presidents over the age of 60 practiced the full four-frame leadership style $3.8 \%$ more frequently (28.6\%). Presidents under 60 employed the three-framed structural-human resources-symbolicframe $5.8 \%$ more frequently $(8.3 \%)$ (see Table 19$)$.

Tests of statistical significance did not reveal any relationships. A Chi-Square analysis was conducted and found no significant relationship between leadership styles and age at the .05 level, $\chi^{2}(3, \mathrm{n}=252)=2.57, p>.05$. The critical value of 7.82 was not transcended. A Pearson's correlation coefficient was calculated and found that there was no statistically significant relationship between leadership style and age, $\mathrm{r}=-.005, \mathrm{n}=252, p>.05$. 
Table 19

Leadership Styles and Frames by Age

\begin{tabular}{|c|c|c|c|c|c|c|}
\hline Frame Utilized & $<60$ & $\%$ & $>60$ & $\%$ & $\chi^{2}$ & $r$ \\
\hline & & & & & 2.57 & -.005 \\
\hline No-frame & 14 & 10.5 & 18 & 15.1 & & \\
\hline \multicolumn{7}{|l|}{ Single-frame } \\
\hline Structural & 4 & 3.0 & 7 & 5.9 & & \\
\hline Human Resource & 14 & 10.5 & 18 & 15.1 & & \\
\hline Political & 3 & 2.3 & 1 & 0.8 & & \\
\hline Symbolic & 4 & 3.0 & 2 & 1.7 & & \\
\hline Total & 25 & 18.8 & 28 & 23.5 & & \\
\hline \multicolumn{7}{|l|}{ Paired-frame } \\
\hline Structural-Human Resource & 11 & 8.3 & 14 & 11.8 & & \\
\hline Structural-Political & 0 & 0.0 & 1 & 0.8 & & \\
\hline Structure-Symbolic & 1 & 0.8 & 0 & 0.0 & & \\
\hline Human Resource-Political & 3 & 2.3 & 3 & 2.5 & & \\
\hline Human Resource-Symbolic & 14 & 10.5 & 4 & 3.4 & & \\
\hline Political-Symbolic & 3 & 2.3 & 2 & 1.7 & & \\
\hline Total & 32 & 24.1 & 24 & 20.2 & & \\
\hline \multicolumn{7}{|l|}{ Multi-Frame } \\
\hline Structural-Human Resource-Political & 4 & 3.0 & 2 & 1.7 & & \\
\hline Structural-Human Resource-Symbolic & 11 & 8.3 & 3 & 2.5 & & \\
\hline Structural-Political-Symbolic & 6 & 4.5 & 3 & 2.5 & & \\
\hline Human Resources-Political-Symbolic & 8 & 6.0 & 7 & 5.9 & & \\
\hline Four-frame & 33 & 24.8 & 34 & 28.6 & & \\
\hline Total & 62 & 46.6 & 49 & 41.2 & & \\
\hline
\end{tabular}

\section{Marital Status}

The initial analysis focused on descriptive statistics to examine the styles and frames by marital status. Then, a Chi-Square goodness of fit test was performed to determine if statistically significant differences occurred. The variables were then reformatted into two options so that this 
dummy variable could undergo a Pearson's correlation to determine if a statistically significant relationship existed.

Most presidents were married (79.1\%). The fifty-two unmarried presidents represented four types of single relationships. In addition, the unmarried presidents' statistic may be skewed due to presidential posts held by members of the Catholic clergy $(10.2 \%)$.

An analysis was conducted by comparing the responses of married and unmarried presidents. Even though both groups of presidents most frequently employed the multi-frame leadership style, married president the full four-frame style more often (7.9\%). Usage of the paired-frame was consistent by both groups; however, unmarried presidents employed singlestyle leadership more than married participants (6.0\%) (see Table 20). Married presidents utilized the human resource-frame more $(5.6 \%)$ than their unmarried counterparts; however unmarried presidents employed the structural frame more frequently $(6.7 \%)$ (see Table 20$)$.

Tests of statistical significance did not reveal any noteworthy relationships. A Chi-Square analysis was conducted and found no significant relationship between leadership styles and marital status at the .05 level, $\chi^{2}(3, n=252)=.77, p>.05$. This very low result was distant from the critical value of 7.82. A Pearson's correlation coefficient was calculated and found no statistically significant relationship between leadership style and marital status, $\mathrm{r}=-.052, \mathrm{n}=$ $253, p>.05$. 
Table 20

Leadership Styles and Frames by Marital Status

\begin{tabular}{|c|c|c|c|c|c|c|}
\hline Frame Utilized & Married & $\%$ & Un-Married & $\%$ & $\chi^{2}$ & $r$ \\
\hline & & & & & 0.77 & -.052 \\
\hline No-frame & 26 & 12.4 & 6 & 11.5 & & \\
\hline \multicolumn{7}{|l|}{ Single-frame } \\
\hline Structural & 6 & 2.9 & 5 & 9.6 & & \\
\hline Human Resource & 28 & 13.3 & 4 & 7.7 & & \\
\hline Political & 3 & 1.4 & 1 & 1.9 & & \\
\hline Symbolic & 3 & 1.4 & 3 & 5.8 & & \\
\hline Total & 40 & 19.0 & 13 & 25.0 & & \\
\hline \multicolumn{7}{|l|}{ Paired-frame } \\
\hline Structural-Human Resource & 20 & 9.5 & 6 & 11.5 & & \\
\hline Structural-Political & 1 & 0.5 & 0 & 0.0 & & \\
\hline Structure-Symbolic & 1 & 0.5 & 0 & 0.0 & & \\
\hline Human Resource-Political & 6 & 2.9 & 0 & 0.0 & & \\
\hline Human Resource-Symbolic & 14 & 6.7 & 4 & 7.7 & & \\
\hline Political-Symbolic & 3 & 1.4 & 2 & 3.8 & & \\
\hline Total & 45 & 21.4 & 12 & 23.1 & & \\
\hline \multicolumn{7}{|l|}{ Multi-frame } \\
\hline Structural-Human Resource-Political & 6 & 2.9 & 0 & 0.0 & & \\
\hline Structural-Human Resource-Symbolic & 9 & 4.3 & 5 & 9.6 & & \\
\hline Structural-Political-Symbolic & 7 & 3.3 & 2 & 3.8 & & \\
\hline Human Resources-Political-Symbolic & 11 & 5.2 & 4 & 7.7 & & \\
\hline Four-frame & 57 & 27.1 & 10 & 19.2 & & \\
\hline Total & 90 & 42.9 & 21 & 40.4 & & \\
\hline
\end{tabular}




\section{Academic Background and Expertise}

The initial analysis focused on descriptive statistics to examine the styles and frames by academic background and expertise. Then, a Chi-Square goodness of fit test was performed to determine if statistically significant differences occurred. The variables were then reformatted into two options so that this dummy variable could undergo a Pearson's correlation to determine if a statistically significant relationship existed. Although there were seven categories of academic expertise, education (31.1\%) and social sciences (27.6\%) appeared most frequently and accounted for nearly $60 \%$ of the responses.

In addition, with relation to the highest degree earned by Masters I presidents, an overwhelming percentage of presidents had earned doctorates (89.7\%). The Ph. D. was the predominant terminal degree (73.6\%). The Ed. D. accounted for only $16.1 \%$ of the cases and only $6.7 \%$ held a master's degree.

Although the multi-framed leadership style was the most frequently cited by all respondents, presidents with doctoral degrees exhibited the use of this frame more than presidents without doctorates (5.8\%). Further, presidents with a doctoral degree utilized the full four-frame style more frequently (16.6\%) Presidents without doctorates were more likely to utilize a paired frame leadership style (5.0\%)(see Table 21).

Respondents with doctorates practiced the Structural-Human Resource frame more than respondents without doctorates $(2.8 \%)$. Conversely, respondents without a doctorate utilized the paired-frame human resource-symbolic-frame more often than respondents with doctorates $(9.3 \%)$

Tests of statistical significance did not reveal any relationships. A Chi-Square analysis was conducted and found no significant relationship between leadership styles and educational 
background at the .05 level, $\chi^{2}(3, \mathrm{n}=254)=.61, p>.05$. This result pales in comparison to the critical value of 7.82 needed for significance. A Pearson's correlation coefficient was calculated and found no statistically significant relationship between leadership style and educational background, $\mathrm{r}=+.004, \mathrm{n}=254, p>.05$.

Table 21

Leadership Styles and Frames by Educational Background

Frame Utilized

No-frame

Single-frame

Structural

Human Resource

Political

Symbolic

Total

Paired-frame

Structural-Human Resource

Structural-Political

Structure-Symbolic

Human Resource-Political

Human Resource-Symbolic

Political-Symbolic

Total

\section{Doctorate}

29

$\begin{array}{rrrr}10 & 4.4 & 1 & 3.8 \\ 28 & 12.3 & 4 & 15.4 \\ 4 & 1.8 & 0 & 0.0 \\ 6 & 2.6 & 0 & 0.0 \\ 48 & 21.1 & 5 & 19.2\end{array}$

$\begin{array}{rrrr}24 & 10.5 & 2 & 7.7 \\ 1 & 0.4 & 0 & 0.0 \\ 0 & 0.0 & 1 & 3.8 \\ 6 & 2.6 & 0 & 0.0 \\ 14 & 6.1 & 4 & 15.4 \\ 5 & 2.2 & 0 & 0.0 \\ 50 & 21.9 & 7 & 26.9\end{array}$

Multi-frame

Structural-Human ResourcePolitical Structural-Human ResourceSymbolic

Structural-Political-Symbolic Human Resources-PoliticalSymbolic

Four-frame

Total

$\begin{array}{rrrr}4 & 1.8 & 2 & 7.7 \\ 14 & 6.1 & 0 & 0.0 \\ 7 & 3.1 & 2 & 7.7 \\ & & & \\ 12 & 5.3 & 3 & 11.5 \\ 64 & 28.1 & 3 & 11.5 \\ 101 & 44.3 & 10 & 38.5\end{array}$

15.4

.0

$\begin{array}{cc}\chi^{2} & r \\ 0.61 & +.004\end{array}$




\section{Last Position Held}

The initial analysis focused on descriptive statistics to examine the styles and frames by last position held. Then, a Chi-Square goodness of fit test was performed to determine if statistically significant differences occurred. The variables were then reformatted into two options so that this dummy variable could undergo a Pearson's correlation to determine if a statistically significant relationship existed. The pathway to the presidency remains through academic affairs as the majority of respondents testified that their last position was an academic vice-president, dean or chair $(46.9 \%)$. The second highest ranked position was that of president at another institutions (26.0\%). Analyses were conducted on these top two previously held positions. First, the respondents were grouped by prior presidents and non-presidents. Second, respondents were grouped by chief academic officers (CAO) and non-chief academic officers.

The multi-framed leadership style was the most frequently by all respondents. Previous president exhibited this style more often (5.0\%) than presidents coming from academic affairs. Conversely, presidents from academic affairs utilized the paired frame style more frequently than respondents who were prior presidents (7.4\%) (see Table 22).

The structural-human resource-frame was utilized most (19.4\%) by respondents who had not come been president at another institution or had come from academic affairs.

Tests of statistical significance did not reveal any worthwhile relationships. A Chi-Square analysis was conducted and found no significant relationship between leadership frames and being a prior president at the .05 level, $\chi^{2}(3, \mathrm{n}=252)=4.82, p>.05$. This finding was less than the 
critical value of 7.82 needed for significance. A Pearson's correlation coefficient was calculated and found no statistically significant relationship between leadership style and prior position, $\mathrm{r}=+.028, \mathrm{n}=252, p>.05$.

The analysis was repeated to gauge any relationships the leadership style of presidents who were previously a CAO. A Chi-Square analysis was conducted and found no significant relationship between leadership styles and being a prior president at the .05 level, $\chi^{2}(3, n=252)=$ $1.48, p>.05$. This result did not exceed the critical value of 7.82 to achieve significance. A Pearson's correlation coefficient was calculated and found no statistically significant relationship between leadership style and the prior position held as a CAO, $\mathrm{r}=-.020, \mathrm{n}=252, p>.05$. 
Table 22

Leadership Styles and Frames by Last Position Held

\begin{tabular}{|c|c|c|c|c|c|c|c|}
\hline Frame Utilized & President & $\%$ & $\mathrm{CAO}$ & $\%$ & Other & $\%$ & $\chi^{2}$ \\
\hline & & & & & & & 4.82 \\
\hline No-frame & 8 & 12.1 & 18 & 15.1 & 6 & 9.0 & \\
\hline \multicolumn{8}{|l|}{ Single-frame } \\
\hline Structural & 3 & 4.5 & 6 & 5.0 & 2 & 3.0 & \\
\hline Human Resource & 10 & 15.2 & 17 & 14.3 & 5 & 7.5 & \\
\hline Political & 3 & 4.5 & 1 & 0.8 & 0 & 0.0 & \\
\hline Symbolic & 2 & 3.0 & 2 & 1.7 & 2 & 3.0 & \\
\hline Total & 18 & 27.3 & 26 & 21.8 & 9 & 13.4 & \\
\hline \multicolumn{8}{|l|}{ Paired-frame } \\
\hline Structural-Human Resource & 4 & 6.1 & 8 & 6.7 & 13 & 19.4 & \\
\hline Structural-Political & 0 & 0.0 & 1 & 0.8 & 0 & 0.0 & \\
\hline Structure-Symbolic & 0 & 0.0 & 0 & 0.0 & 1 & 1.5 & \\
\hline Human Resource-Political & 1 & 1.5 & 5 & 4.2 & 0 & 0.0 & \\
\hline Human Resource-Symbolic & 3 & 4.5 & 8 & 6.7 & 7 & 10.4 & \\
\hline Political-Symbolic & 1 & 1.5 & 3 & 2.5 & 1 & 1.5 & \\
\hline Total & 9 & 13.6 & 25 & 21.0 & 22 & 32.8 & \\
\hline \multicolumn{8}{|l|}{ Multi-frame } \\
\hline Structural-Human Resource-Political & 1 & 1.5 & 5 & 4.2 & 0 & 0.0 & \\
\hline Structural-Human Resource-Symbolic & 2 & 3.0 & 8 & 6.7 & 4 & 6.0 & \\
\hline Structural-Political-Symbolic & 2 & 3.0 & 3 & 2.5 & 4 & 6.0 & \\
\hline Human Resources-Political-Symbolic & 6 & 9.1 & 4 & 3.4 & 5 & 7.5 & \\
\hline Four-frame & 20 & 30.3 & 30 & 25.2 & 17 & 25.4 & \\
\hline Total & 31 & 47.0 & 50 & 42.0 & 30 & 44.8 & \\
\hline
\end{tabular}

Note: $C A O=$ Chief Academic Officer 
Research Question Four. Is there a statistically significant difference in leadership style of individuals who are first time presidents and repeat presidents?

The initial analysis focused on descriptive statistics to examine the styles and frames by first time and repeat presidents. Then, a Chi-Square goodness of fit test was performed to determine if statistically significant differences occurred. The variables were then reformatted into two options so that this dummy variable could undergo a Pearson's correlation to determine if a statistically significant relationship existed.

The demographic responses revealed that nearly all the participants (95.7\%) were permanent presidents. Furthermore, there was an overwhelmingly amount of first time presidents $(70.5 \%)$. Second presidencies accounted for $20.1 \%$, and respondents who had three or more presidencies represented $9.1 \%$ of the surveyed population (see Table 23).

Even though the multi-framed leadership style was the most prevalent style employed by both groups, respondents who had multiple presidencies utilized this style more often (4.8\%). Conversely, first-time presidents employed the paired leadership style more often than repeat presidents $(8.4 \%)$. Both groups utilized the no-frame style the least and in the same ratio (see Table 23).

First-time presidents employed more frequently the paired frames of structural-human resources and the human resource-symbolic (4.4\%), (2.4\%), respectively. However, respondents who had multiple presidencies employed the three-framed combination of the human resourcepolitical-symbolic-frame by more often (5.0\%). Moreover, respondents with multiple 
presidencies exercised the full four-frame style more frequently $(4.6 \%)$ than first-time presidents (see Table 23).

Tests of statistical significance did not reveal any noteworthy relationships A Chi-Square analysis was performed and did not yield a significant relationship at the .05 level, $\chi^{2}(3, n=253)$ $=2.57, p>.05$. This finding did not exceed the critical value of 7.82 for significance. A Pearson correlation was conducted and found no statistically significant relationship between the leadership frames utilized by first time presidents and the frames utilized by repeat presidents, $\mathrm{r}=-.006, \mathrm{n}=253, p>.05$. 
Table 23

Leadership Style and Frames by the Number of Presidencies

\begin{tabular}{|c|c|c|c|c|c|c|}
\hline Frame Utilized & First & $\%$ & Multiple & $\%$ & $\chi^{2}$ & $r$ \\
\hline & & & & & 2.57 & -.006 \\
\hline No-frame & 24 & 13.4 & 9 & 12.2 & & \\
\hline \multicolumn{7}{|l|}{ Single-frame } \\
\hline Structural & 8 & 4.5 & 3 & 4.1 & & \\
\hline Human Resource & 22 & 12.3 & 10 & 13.5 & & \\
\hline Political & 1 & 0.6 & 3 & 4.1 & & \\
\hline Symbolic & 4 & 2.2 & 2 & 2.7 & & \\
\hline Total & 35 & 19.6 & 18 & 24.3 & & \\
\hline \multicolumn{7}{|l|}{ Paired-frame } \\
\hline Structural-Human Resource & 20 & 11.2 & 5 & 6.8 & & \\
\hline Structural-Political & 1 & 0.6 & 0 & 0.0 & & \\
\hline Structure-Symbolic & 0 & 0.0 & 1 & 1.4 & & \\
\hline Human Resource-Political & 4 & 2.2 & 2 & 2.7 & & \\
\hline Human Resource-Symbolic & 14 & 7.8 & 4 & 5.4 & & \\
\hline Political-Symbolic & 5 & 2.8 & 0 & 0.0 & & \\
\hline Total & 44 & 24.6 & 12 & 16.2 & & \\
\hline \multicolumn{7}{|l|}{ Multi-frame } \\
\hline Structural-Human Resource-Political & 5 & 2.8 & 1 & 1.4 & & \\
\hline Structural-Human Resource-Symbolic & 12 & 6.7 & 2 & 2.7 & & \\
\hline Structural-Political-Symbolic & 6 & 3.4 & 3 & 4.1 & & \\
\hline Human Resources-Political-Symbolic & 8 & 4.5 & 7 & 9.5 & & \\
\hline Four-frame & 45 & 25.1 & 22 & 29.7 & & \\
\hline Total & 76 & 42.5 & 35 & 47.3 & & \\
\hline
\end{tabular}


Research Question Five. Is there a statistically significant difference in leadership style of individuals who have less than one year of experience as a president, between one and five years of experience as a president, between six and ten years of experience as a president, between eleven and fifteen years of experience as a president, and more than fifteen years of experience as a president?

The initial analysis focused on descriptive statistics to examine the styles and frames by years of experience as a president. The variables were then reformatted into two options so that this dummy variable could undergo a Pearson's correlation to determine if a statistically significant relationship existed. Then, a Chi-Square goodness of fit test was performed to determine if statistically significant differences occurred.

The respondents' term as president varied greatly in this study. Only $3.1 \%$ had been a president for less than one year, however $29.5 \%$ had been president between one and five years, and $27.2 \%$ had been presidents for six to ten years. Thus, nearly $60 \%$ of the surveyed population had been a president for ten years of less. Respondents reported that $14.6 \%$ had been president for eleven to fifteen years and $25.2 \%$ of respondents had been president for more than fifteen years, thereby revealing that presidents with eleven or more years of experience comprised nearly $40 \%$ of the surveyed population (see Table 24 ).

Once again, the multi-framed leadership style was most practiced by all the groups. Presidents with less than ten years of experience utilized a paired-frame leadership style more often than presidents with more than eleven years of experience $(8.9 \%)$. Presidents with more 
than eleven years of experience utilized the single-frame and no-frame style more than presidents with less years of experience (3.1\%)(see Table 24).

The paired-frame of structural-human resources was utilized more by presidents with less than ten years of service (4.9\%). In addition, these presidents employed the three-framed combination of the structural-human resource-symbolic-frame more than presidents with more years of experience $(5.9 \%)$. However, the presidents with more than eleven years of service employed the full four-frame style more frequently than their counterparts (7.0\%) (see Table 24). Tests of statistical significance did not reveal any striking relationships. A Chi-Square analysis was performed and did not yield a significant relationship at the .05 level $\chi^{2}(4, \mathrm{n}=253)$ $=2.93, p>.05$. The critical value of 9.49 was not exceeded for significance. A Pearson correlation was performed and found no statistically significant relationship between the number of years as a president and the type of leadership style used, $\mathrm{r}=+.029, \mathrm{n}=253, p>.05$. 
Table 24

Leadership Styles and Frames by Years as a President

\begin{tabular}{lcccccc} 
Frame Utilized & $<10$ & $\%$ & $>11$ & $\%$ & $\chi^{2}$ & $r$ \\
\hline No-frame & 18 & 11.8 & 15 & 14.9 & &
\end{tabular}

Single-frame

Structural

Human Resource

Political

Symbolic

Total

$\begin{array}{rrrr}5 & 3.3 & 6 & 5.9 \\ 18 & 11.8 & 14 & 13.9 \\ 2 & 1.3 & 2 & 2.0 \\ 5 & 3.3 & 1 & 1.0 \\ 30 & 19.7 & 23 & 22.8\end{array}$

Paired-frame

Structural-Human Resource

$\begin{array}{llll}18 & 11.8 & 7 & 6.9\end{array}$

Structural-Political

$\begin{array}{llll}0 & 0.0 & 1 & 1.0\end{array}$

Structure-Symbolic

$\begin{array}{llll}0 & 0.0 & 1 & 1.0\end{array}$

Human Resource-Political

$\begin{array}{llll}4 & 2.6 & 2 & 2.0\end{array}$

Human Resource-Symbolic

$\begin{array}{llll}13 & 8.6 & 5 & 5.0\end{array}$

Political-Symbolic

$\begin{array}{llll}4 & 2.6 & 1 & 1.0\end{array}$

Total

$\begin{array}{llll}39 & 25.7 & 17 & 16.8\end{array}$

Multi-frame

$\begin{array}{lrrrr}\text { Structural-Human Resource-Political } & 4 & 2.6 & 2 & 2.0 \\ \text { Structural-Human Resource-Symbolic } & 12 & 7.9 & 2 & 2.0 \\ \text { Structural-Political-Symbolic } & 4 & 2.6 & 5 & 5.0 \\ \text { Human Resources-Political-Symbolic } & 9 & 5.9 & 6 & 5.9 \\ \text { Four-frame } & 36 & 23.7 & 31 & 30.7 \\ \text { Total } & 65 & 42.8 & 46 & 45.5\end{array}$




\section{Summary}

This chapter presented the results from analyzing the leadership styles of Masters I presidents. Bolman and Deal's Leadership Orientations (Self) instrument was mailed to all 494 Masters I presidents as categorized by the Carnegie Foundation, 2001. After three mailings, a total of 254 valid responses $(51.4 \%)$ were returned.

The five research questions presented in Chapter 1 were used to direct this study. Statistical analysis was performed via the frequencies, means, standard deviations, chi-square, and Pearson correlation. An alpha level of .05 was used as the criterion to establish significance.

Primarily, a one-way Chi-Square analysis discovered a statistically significant difference in the leadership styles utilized. As a consequence, it was found that presidents of Masters I institutions predominantly utilized a multi-style approach followed by a paired-style leadership style, a single-style leadership style and finally, a no-style leadership orientation. The frames utilized in descending order were human resources, structural, political, symbolic and no-frame.

Secondly, no statistically significant differences were found in leadership style affected by institutional variables such as size of institution, geographic location, community population, and type of control.

Thirdly, no statistically significant differences in leadership style appear with respect to demographic characteristics such as gender, race, age, marital status, educational background, and last position held.

Fourthly, no statistically significant differences in leadership style appeared between first-time presidents or repeat presidents. 
Finally, no statistically significant differences in the leadership style of respondents who had less than eleven years of experience as a president and those who had more than ten years of experience as a president was found. 


\section{CHAPTER 5}

Conclusions and Recommendations

This chapter reports the conclusions pursuant to the findings derived from the general demographic characteristics and the five research questions that guided this study in relation to the leadership styles of Masters I presidents. In addition, recommendations for practice and recommendations for further study are included.

\section{Demographics}

This study found most (86.6\%) presidents were Caucasian. Nearly $77 \%$ of the respondents were male, and the majority (79.1\%) was married. An earned doctoral degree was most prevalent (89.7\%) among the respondents. Nearly one-third of the presidents' academic expertise was in education. In addition, almost half (49.2\%) of the presidents were between the ages of 50 and 60 years of age. First time presidents accounted for $70.5 \%$ of the respondents. The largest single group of respondents (47.2\%) indicated academic affairs as their last position.

This study's demographic findings are congruent with Corrigan's survey (2002) of the presidents of all American higher education institutions by Carnegie Classification. Corrigan's respondents were mainly Caucasian (87.2\%), male (78.9\%), married (83.1\%), with an earned doctorate (55.6\%), a background in education (43.8\%), and were between 50 and 60 years of age (57.3). Most (73.6\%) respondents indicated this their first presidency, and the largest single group (40.8\%) reached the presidency after holding a senior position in academic affairs.

With respect to the Master's level presidents in Corrigan's survey, those leaders not only had the same demographic patterns as the presidents in general, and but also with the demographic patterns in this study (see Table 25). 
However, there were a few interesting differences between Corrigan's Master's level leaders and this study's findings. The respondents in this study were less likely $(9.7 \%)$ to have served in the presidency for less than five years. Conversely, respondents in this study comprised a much higher percentage $(17.5 \%)$ of presidents with over 15 years of service. In addition, respondents in this study who had a prior position in finance were less likely $(10.2 \%)$ to reach the presidency than their counterparts. Nevertheless, despite these variances, no statistically significant relationships emerged. A Chi-Square analysis was conducted and since the critical value of 21.03 was not exceeded, no significant relationship was found between leadership styles and gender at the .05 level, $\chi^{2}(12, \mathrm{n}=253)=10.27, p>.05$. 
Table 25

Comparison of this Study with Corrigan

\begin{tabular}{llll}
\hline Demographic & $\begin{array}{l}\text { Corrigan Corrigan } \\
\text { Characteristics }\end{array}$ & This Variance Variance \\
(Total) & (Masters) & Study to Total to Masters \\
\hline
\end{tabular}

Status

$\begin{array}{lrrrrr}\text { Interim } & 3.9 & 3.2 & 4.3 & 0.4 & 1.1 \\ \text { Permanent } & 96.1 & 96.8 & 95.7 & -0.4 & -1.1\end{array}$

Number of Presidencies

$\begin{array}{lrrrrr}\text { First } & 73.6 & 76.1 & 70.8 & -2.8 & -5.3 \\ \text { Second or more } & 26.4 & 23.9 & 29.2 & 2.8 & 5.3\end{array}$

Years as President

$\begin{array}{lrrrrr}\text { Less than 1 year } & 8.9 & 6.8 & 3.2 & -5.7 & -3.6 \\ \text { Between 1-5 years } & 40.3 & 35.7 & 29.6 & -10.7 & -6.1 \\ \text { Between 6-10 years } & 27.9 & 30.8 & 27.3 & -0.6 & -3.5 \\ \text { Between 11-15 years } & 13.8 & 19.1 & 14.6 & 0.8 & -4.5 \\ \text { Over 15 years } & 9.1 & 7.8 & 25.3 & 16.2 & 17.5\end{array}$

Previous Position

$\begin{array}{lrrrrr}\text { President } & 20.4 & 18.0 & 26.2 & 5.8 & 8.2 \\ \text { Academic VP } & 40.8 & 44.3 & 47.2 & 6.4 & 2.9 \\ \text { Development } & 3.7 & 4.6 & 5.2 & 1.5 & 0.6 \\ \text { Student Affairs } & 3.2 & 2.5 & 5.2 & 2.0 & 2.7 \\ \text { Finance } & 12.8 & 15.8 & 5.6 & -7.2 & -10.2\end{array}$

Age

$\begin{array}{lrrrrr}\text { Under 50 } & 12.5 & 5.9 & 3.6 & -8.9 & -2.3 \\ \text { Between 50 and 60 } & 57.3 & 60.0 & 49.2 & -8.1 & -10.8 \\ \text { Over 60 } & 30.3 & 34.2 & 47.2 & 16.9 & 13.0\end{array}$

Race

$\begin{array}{lrrrrr}\text { Caucasian } & 87.2 & 87.1 & 86.6 & -0.6 & -0.5 \\ \text { Non-Caucasian } & 12.8 & 12.9 & 13.4 & 0.6 & 0.5\end{array}$




\begin{tabular}{lrrrrr}
\hline $\begin{array}{l}\text { Demographic } \\
\text { Characteristics }\end{array}$ & $\begin{array}{l}\text { Corrigan Corrigan } \\
\text { (Total) }\end{array}$ & $\begin{array}{l}\text { This } \\
\text { (Masters) }\end{array}$ & $\begin{array}{l}\text { Study } \\
\text { Variance }\end{array}$ & $\begin{array}{l}\text { Variance } \\
\text { to Total to Masters }\end{array}$ \\
\hline Highest Degree Earned & & & & & \\
Ph. D. & 55.6 & 76.9 & 73.6 & 18.0 & -3.3 \\
Ed. D. & 20.8 & 12.7 & 16.1 & -4.7 & 3.4 \\
J.D. & 4.2 & 2.5 & 2.0 & -2.2 & -0.5 \\
$\quad$ Masters & 11.4 & 4.5 & 6.7 & -4.7 & 2.2 \\
& & & & & \\
Academic Expertise & & & & & \\
$\quad$ Education & 43.8 & 31.7 & 31.1 & -12.7 & -0.6 \\
$\quad$ Social Sciences & 14.3 & 24.6 & 27.6 & 13.3 & 3.0 \\
$\quad$ Fine Arts & 13.5 & 18.7 & 17.7 & 4.5 & -0.7 \\
& & & & & \\
Marital Status & & & & & \\
$\quad$ Married & 83.1 & 79.8 & 79.4 & -3.7 & -0.4 \\
$\quad$ Unmarried & 16.9 & 20.2 & 20.6 & 3.7 & 0.4 \\
& & & & & \\
Gender & & & & & \\
$\quad$ Female & 21.1 & 20.3 & 23.2 & 2.1 & 2.9 \\
$\quad$ Male & 78.9 & 79.7 & 76.8 & -2.1 & -2.9 \\
& & & & & \\
\hline
\end{tabular}

Other studies yielded comparable demographic findings. Shawver (1985) compiled a portrait of the 65 presidents who were members of the American Association of State Colleges, and likewise found the majority of presidents held doctorates, were white, male, and married. Reece (1997) profiled female presidents in the Southeast and found the president had a Ph.D., had been in office five years or less. This study found the largest group of female presidents totaling $24 \%$ were married with a Ph.D. and with less than 5 years in the position.

Thus, this study and the literature confirm that the demographic portrait of presidents have been remarkably stable. 


\section{Conclusions}

\section{Leadership Styles}

Single, paired, and multi are the major leadership styles. Contained within them are the specific leadership frames. Within the single leadership style exists the four major frames: structural, human resource, political, and symbolic. These frames can be used alone, or in combination with other frames. In cases where the presidents' responses failed to reach the threshold for frame usage, the no-frame style was employed.

The findings for first research question that examined the leadership style revealed a significant difference in the leadership approaches among the respondents. This finding points to the multi-style as the predominant approach and the no-style as the least used, the multi-frame having a statistically significant difference.

The role of a university president is very complex and demanding. Incumbents must deal with multiple internal and external constituencies over a vast array of challenges and opportunities. To effectively lead, presidents must be able to examine and address problems from multiple vantage points. The literature confirms that multi-framed leadership style provides more versatility and options to respond to problems. This finding supports the contention of Bolman and Deal (1991) that given the complex nature of the contemporary presidency, the use of at least three frames is critical to effectively lead the organization, even though only two of their studies have confirmed this assertion thus far.

At the presidential level, no leadership frame studies examined the Masters I presidents. Most of the research centers on doctoral level institutions and it reveals that both internal and external interactions require at least three frames to be effective. Gamble (2003) in a small study of doctoral universities found that all four of the presidents utilized the multi-style approach at 
different times. Similarly, Magnuson (2002) found 40\% of presidents of doctoral and masters' institutions utilized multi-style leadership. So too, did the respondents of this study.

Bensimon (1989) conducted the only other major study of higher education presidents. Her study involved leaders from research universities, four-year institutions, and community colleges. Across all three levels of institutions, she found the single frame style was the most prevalent (41\%) and the multi-framed orientation was the least utilized (25\%). Among the fouryear presidents, the patterns were similar.

The only other studies conducted thus far on presidential leadership using the four-frames model centered on the ethnic, racial, and gender composition, and length of experience of the respondents. Thus, in most of the leadership frame studies conducted thus far, including this one, the multi-frame approach surfaced with greater frequency than did the other approaches.

\section{Leadership Style Studies of Other Higher Education Positions}

Not only have previous studies of university and college presidents found that the multistyle approach was used predominantly, but studies of leaders at other levels in institutions of higher education have reported similar results. The importance of multi-framed style appears at levels below the presidency. For example, Russell (2000) examined the leadership frames of community college deans and found nearly half utilized multiple-styles. Becker (1999) found two-thirds of chief information officers utilized this style. Similarly, Wolf (1998) found that twothirds of campus safety directors utilized multiple styles. In addition, Turley (2002) found $44 \%$ of radiation therapy program directors espoused multi-style leadership. However, in a study of nursing chairpersons, Small (2002) did not find the multi-style leadership as the predominant approach (These unit heads used the no-frame style most frequently). Thus, the multi-framed 
leadership style appears to be utilized with similar frequencies at levels below the presidency as it does at the presidential level.

\section{Leadership Frames}

Embedded within the leadership style are the leadership frames. The four major frames are the structural, human resources, political, and symbolic frame. The findings in the first research question also delineated the specific leadership frames utilized by the presidents, consistent with Bolman and Deals method of reporting the data. These frames were utilized in the following descending order: human resources (30.7\%), structural (22.5\%), symbolic (22.5\%), political (18.8\%), and the no-frame (5.5\%).

In the myriad of studies by Bolman and Deal, the human resources-frame does not appear most frequently. The structural and symbolic frames were most frequently employed. Similarly, Bensimon (1989) found that the majority of presidents in her study did not have this frame as their highest choice. The human resources frame was the second most utilized type. Concurring with Bensimon, Jablonski, (1992) found the majority of female college presidents utilized the structural frame. Thus the Master's level leaders in this study rely on a different leadership frame than did presidents at other Carnegie Classification levels.

\section{Frame Studies of Other Higher Education Positions}

Even though the human resource-frame was used less frequently in studies examining the presidency, it appears more often in the complementary research. Cantu (1997) studied the leadership frames of academic deans and found the human resource-frame the most utilized, followed by the structural, political, and the symbolic frames. Russell (2000) examined the leadership frames of community college deans and found the human resource-frame the most prevalent. Mosser (2000) obtained comparable results by analyzing nursing chairpersons and 
found the human resource-frame was the most utilized followed by the structural, symbolic, and the political-frame. Kane (2001) and Travis (1996) both found that student affairs officers utilized the human resource-frame most frequently. Wolf (1998) found that campus safety directors most utilized the human resource frame. Turley (2002) studied radiation therapy program directors and found the human resource-frame followed by the structural-frame were the most frequently employed. Therefore, the leadership frame preference of Master's level presidents is consistently congruent with leaders in positions below the presidency at various institutional levels. This may indicate a need for different techniques at these Master's institutions.

Institutional Variables and Leadership Styles

Institutional Enrollment. This study did not find any statistically significant relationships between the presidents' leadership style and the institutional enrollment. Bechtle (1993) studied the leadership style among Bible College presidents and found no significant statistical relationship between leadership style and the size of the institution. Wise (1984) examined the leadership behavior of liberal arts college presidents and found that enrollment did not significantly influence the leadership behavior of the college presidents. Spivey (1983) studied the leadership styles of presidents from historically Black higher education institutions in the Southwestern and Southeastern United States and found no significant difference the perception of the presidents' leadership style and size of the student population.

However, Cobelli (1989) found that organizational structure and size determined the way administrators made decisions, and Gubanich (1991) concluded that presidents of smaller schools tended to be younger, less prone to burn out, more likely to use a participating style. 
Community Size. This study did not find any statistically significant relationships between the presidents' leadership style and the size of the community population in which the institution was located. Spivey (1983) studied the leadership styles of presidents from historically Black higher education institutions in the southwestern and southeastern United States and found no significant difference of the presidents' leadership style by community size.

Location. This study did not find any statistically significant relationships between the presidents' leadership style and the geographic location of the institution. Wise (1984) examined the leadership behavior of liberal arts college presidents found the location of the colleges did not significantly influence the presidents' leadership behavior. Spivey (1983) studied the leadership styles of presidents from historically Black higher education institutions and found no significant difference between the presidents' leadership style and location.

Institutional Type. This study did not find any statistically significant relationships between the presidents' leadership style and institutional type since this was a homogeneous study of Masters I presidents. However, Bensimon (1989) found that multi-frame orientation was much more prevalent in the university than in community colleges, and conversely, the single-frame orientation was much more prevalent in community colleges than in universities.

Type of Control. This study did not find any statistically significant relationships between the presidents' leadership style and the institution's type of control. Bensimon (1989) found the usage of frames between public and private institutions were nearly identical. Likewise, Spivey (1983) studied the leadership styles of presidents from historically Black higher education institutions and found no significant difference between the presidents' leadership style and type of control. 
However, Waters (1993) found that minority presidents of private historically black college and universities employed a hierarchical style of leadership style as opposed to minority presidents of public institutions who employed a collegial leadership style. Thus, most studies of leadership styles and organizational characteristics are consistent with the findings of this study. Individual Demographic Variables and Leadership Styles

The findings of the third research question did not yield any statistically significant relationships between the leadership style and the presidents' demographic characteristics.

Gender. This study did not find any statistically significant relationships between the presidents' leadership style and gender. This finding was supported Bolman and Deal (1991) who did not find significant variance in leadership style by gender. In addition, Lockard (2000) found consistent responses in the leadership style of university presidents regardless of gender. Also, Guill (1991) examined the conflict management style preferences of community college presidents and found no significant difference in style preference based on gender. In addition, Kisling (1986) found no statistically significant differences between women presidents of twoyear and four-year institutions of higher education on the basis of social origins, education, and career patterns. Spivey (1983) studied historically Black higher education institutions and found no significant differences between the presidents' leadership style and gender.

However, Chliwniak (1996) found that gender and position provided significant influences on leadership style based on perceptions of others in the institution. Cobelli (1989) found gender affected the way that decisions were made. In addition, Holder (1993) found a statistically significant relationship between the presidents' leadership style and gender, and Macera (1989) studied critical presidential managerial skills and found statistical significance based on gender. 
Age. This study did not find any statistically significant relationships between the presidents' leadership style and president's age. Both Bechtle's (1993) study of the leadership style among Bible College presidents and Spivey's (1983) study of historically Black higher education institutions support this finding. However, Rhodes (1998) found a significant relationship between leadership style and the age of the president.

Race. This study did not find any statistically significant relationships between the presidents' leadership style and the president's race. Spivey (1983) supported this finding. However, Echols Tobe (1999) found 100\% of female African American presidents had multistyle orientations. This study found $60.0 \%$ of female African American presidents had multistyle orientations.

In addition, Waters (1993) found that minority presidents of private historically black college and universities employed a hierarchical style of leadership style as opposed to minority presidents of public institutions who employed a collegial leadership style.

Education. This study did not find any statistically significant relationships between the presidents' leadership style and the president's educational attainment and background. In addition, both Bechtle's (1993) study of the leadership style among Bible College presidents and Spivey's (1983) study of historically Black higher education institutions found no significant statistical relationship between the presidents' education.

Prior Position Held. This study did not find any statistically significant relationships between the presidents' leadership style and the last position held before reaching the presidency. Kane (1997) supported this finding. Similarly, Spivey (1983) studied historically Black higher education institutions and found no significant differences between the presidents' leadership style and last position held. 
The paucity of statistical significance in many leader frame studies is reminiscent of the trait theories of leadership which found that the situation is determinative of the style needed (Bensimon, et al, 1989; Bass, 1991; Bryman, 1996; Yukl, 1994). Tingey (1997) contends that leadership among college and a university president is more complex than commonly understood, and is contextual and situational in nature, thus the personal variables do not play a significant role.

\section{First Time and Repeat Presidents}

The findings of the fourth research question four did not reveal any statistically significant relationships between the leadership style and first-time and repeat presidents. The first-time presidents primarily utilized the multi-frame style followed by the paired-frame style. Repeat presidents most often utilized the multi-frame leadership style followed by the singleframe style.

Contrary to this finding is the work of Bensimon (1989) who found 50\% of first-time presidents utilized a single-frame style, perhaps an extension of the style that they developed over their careers. No other studies have found this association except Bensimon.

\section{Years as a President}

The findings of the fifth research question did not yield any statistically significant relationships between the length of time served as a president. Both presidents with less than ten years experience as a president and those with more than ten years experience utilized the multistyle leadership the most. As a secondary style, presidents with less than ten years of experience utilized a paired frame leadership style more often (8.9\%) than presidents with more than eleven years of experience. Presidents with more than eleven years of experience utilized all four-styles more $(7.0 \%)$ than their counterparts with less experience. 
However, Bensimon found presidents with less than three years experience were more likely to have a single frame leadership style than presidents who had been in the position for five years or more. Further, new presidents were least likely to utilize the multi-frame approach and presidents in the position for five years utilized the paired and multi-frame style.

Welch (2002) found presidents of Doctoral Universities with less than 20 years experience utilized a multi-frame style and presidents with over 20 years experience utilized either the human resource or symbolic style. This study found the majority $(40.5 \%)$ of presidents with less than 15 years of experience employed the multi-style and the majority $(53.1 \%)$ of presidents with more than 15 years experience utilized multi-style as well.

Other studies, such as Lockard (2000) found differences based on the length of the presidency. Ali (1994) found the number of years in administration was a significant factor in the choice of leadership style of presidents of Texas Community Colleges. Similarly, Gilson (1994) found presidents who had five or more years of experience were more likely to use more complex strategies than presidents with less experience. Bechtle (1993) studied the leadership style among Bible College president and found a significant statistical relationship with presidential tenure. Guill (1991) found significant differences in presidents' style based on years of presidential experience. Finally, Wheeler and Tack (1989) found differences in leadership style based on years of experience.

Interim presidents are caretakers for the institution until the next president is selected. Even though only four percent of respondents to this study were interim presidents, their actions can have a profound effect on the institution. Trudeau (2001) studied eight interim presidents at Masters institutions in Minnesota and Wisconsin and found that all relied upon consensus leadership. This is an important finding since the consequences of turnover at the top can be 
immense as searches often take an academic year to complete and institutions can lose momentum in planning, fund raising, staff morale and productivity (Basinger, 2001). Everley (1993) examined the interim presidency at 134 public research/doctorate-granting institutions and found the majority of interim presidents were males and were chosen from within their own institutions from the chief academic affairs position.

The length of term as president has also spawn some popular misconceptions equating success with mobility or length of time in the position is not an indicator of success. "Presidents are like baseball managers. They turn over often, are blamed for what they can't control, and are eagerly accepted by other organizations after they've been given a ticket out of town by their last one" (Hahn, 1995, p.14) "Ironically, among those presidents who stay briefly and move frequently are many regarded as our most successful leaders” (Hahn, 1995, p.17).

It can also be assumed that institutions look for the attributes of their next president to be the opposite of their last president's weaknesses. Climbing the educational career ladder may be quick for some, but once a presidency is obtained, the participants may have achieved their work objectives or may simply be too tired at their stage in life to either relocate or seek yet another fresh challenge.

Usage of the multi-frame style was strongest for presidents who had served in the position over fifteen years. Their longevity and experience with addressing a myriad of problems has allowed them to view and solve the problems from multiple perspectives. 


\section{Recommendations}

\section{Recommendations for Practice}

Presidents who were not multiframed in this study should be encouraged to consider multi-frame leadership training. The workshop training should consist of both a conceptual and an applied approach, including an understanding of the four frames, and the use of simulations, branching, role-playing, and case studies to broaden the presidents' perspective. Training underscores that the presidents must be leaders, and that they be aware of their leadership style that can be achieved through the various assessment center approaches. Multi-frame training is a tool that could assist them. Bolman and Deal underscore Bensimon, who contends that multiple perspectives open up different windows, alternatives and solutions to complex problems.

Attaining the presidency requires substantial education, experience, and maturity. However, the age of the presidents is a matter of concern. As a consequence of their advancing years, it is reasonable to conclude that a large percentage of incumbent presidents will retire in the next ten years. Replacements will be needed in the near future and they must be prepared to address the multiplicity of issue that will confront them. Therefore, it is recommended that training in multi-frame thinking be provided to new, first time presidents through avenues similar to the Harvard School for New Presidents. Furthermore, professional development and training of senior academic, administration, development, and student affairs personnel is needed to prepare prospective candidates for the challenges and opportunities that await them in the presidency.

Institutional governing boards should consider the use of multi-frame thinking as a criterion for future presidents. Prospective candidates and appointees should be encouraged by their boards to participate in multi-frame presidential leadership workshops such as those offered 
by the American Council on Education. In addition, the campus master plan and institutional priorities could also assist in determining the leadership style needed at that particular junction.

Masters I presidents face challenges related to their distinctive mission and their position between the universal access offered at two-year community colleges and the more selective research universities. Political leadership and symbolic leadership may be just as important to these presidents at Colleges in the Middle. Further, training in multi-frame leadership to senior academic deans is critically important since nearly half of presidents have come from this position. Bolman and Deal believed preparation programs for school leaders could be improved by incorporating more training in the political and symbolic frames which are important for success. Ironically, the political and symbolic frames were underutilized in this study.

Similarly, the gender and race of presidents is remarkably homogeneous. Even though women and non-Caucasians are making strides in higher education, they only account for less than one-fourth, and one-eighth of Masters I presidents respectively. Targeted programs to develop women and non-Caucasians as candidates for presidencies are essential since women constitute the majority student population. This could be accomplished by tailoring programs specifically to these groups by advertising in a number of periodicals that reach out to AfricanAmerican and Hispanic professionals.

Even though the majority of presidents were multi-framed, efforts should be made to educate and assess the presidents' senior officers to ensure that their perspectives complement each other for complex decision-making. The presidents' cabinet working collaboratively can effectively address issues from a variety of perspectives. For example, the impact of a decision on the students, finances, faculty, donors, the public and political entities, and other internal and 
external constituencies could be analyzed and could provide the president with alternatives and ramifications of action on a myriad of university issues.

\section{Recommendations for Further Study}

1) Even though most of the results of this study were not significant, the study serves an important function, since it will enable future researchers to focus on other variables.

2) First time presidents comprised over $70 \%$ of this survey's respondents. Future studies should concentrate on soliciting the responses of repeat presidents to achieve a more balanced representation to compare the leadership styles between the two groups. Further, additional research could determine if leadership styles change over time and with more experience.

3) The leadership style of presidents of "Colleges in the Middle" does not appear to be predicated on the demographic variables in this study. There may be another set of variables that are more closely related to their leadership style. For example, organizational climate, faculty job satisfaction, funding patterns, and changes in enrollment, changes in donor levels, senior administrative turnover, and other indices relating to institutional effectiveness. Subsequent studies should examine situational variables particularly the maturity and capability levels of the followers, executive team, and other significant followers inside and outside of the institution.

4) Subsequent research should include the Bolman and Deal (1990) Leadership Orientations (Other) instrument to survey executive staff and members of the president's cabinet at the participating institutions to ascertain if their view of the president's leadership style is related to what the president perceives is being employed.

5) Since $25 \%$ of Masters I presidents were previously presidents, further research might examine the types and size of the institutions they previously headed. This 
data would assist in understanding the multiple presidents' career path. In this way the relationship between the size and type of their previous institution and the size and type of their present institution could be explored?

6) Masters II institutions and the Research Universities should be surveyed using the Bolman and Deal 1990 Leadership Orientations (Self) instrument to determine if differences in leadership styles exist at these institutions.

7) Future studies should compare Masters I institutions with Baccalaureate and Community Colleges. This may prove interesting since women presidents are more prevalent in community colleges and the governance and decision-making at community colleges is more bureaucratic (Bensimon, 1989).

8) Future studies could examine the culture of an institution and attempt to ascertain differences in leadership based on the cultural factors.

9) New studies might examine the presidents' leadership style over time to see if changes occur from their previous position as well as their first and multiple presidencies.

10) Lastly, studies are needed to examine the turnover and appointment of new senior officers with a new president since presidents can have a great impact on the future of their institutions by the staff selections they make (Corrigan 2002). Relationships between leadership style and turnover of executive team could then be explored. 


\section{References}

Agbor-Baiyee, W. (1996). Passion for academic leadership: An investigation of the factors that motivate and provide satisfaction for college and university presidents. Dissertation Abstracts International, 57 (04), 1510A. (UMI No. 9627363)

Ali, H. (1994). Self-perceived administrative leadership styles of presidents, vice-presidents, and deans in public community and junior colleges in Texas. Dissertation Abstracts International, 55 (11), 3422A. (UMI No. 9503911)

Anglis, C. (1990). Career advancement strategies utilized by selected women college and university administrators in a midwestern state. Dissertation Abstracts International, 52 (03), 747A. (UMI No. 9122778)

Argyris, C. (1972). The applicability of organizational sociology. Cambridge: Cambridge University Press.

Arnold, S. (1994). A descriptive study of the characteristics of black women college presidents/chief executive officers. Dissertation Abstracts International, 55 (09), 2651A. (UMI No. 9502835)

Balderson, F. (1995). Managing today's university: Strategies for viability, change and excellence ( $2^{\text {nd }}$ ed). San Francisco: Jossey-Bass.

Baldridge, V., \& Deal, T. (Eds.).(1983). The dynamics of organizational change in education. Berkeley, CA: McCutchan.

Barr, C. (1981). Profiles of American college presidents-1968 and 1980: A comparison. Dissertation Abstracts International, 42 (04), 1386A. (UMI No. 8121513)

Basinger, J. (2001, July 27). When a president quits early, the damage can linger on. Chronicle of Higher Education, A 22. 
Bass, B. M. (1991). Bass and Stogdill's handbook of leadership: A survey of theory and Research. New York: Free Press.

Bass, B. M., \& Avolio, B. J. (1994). Improving organizational effectiveness through transformational leadership. Thousand Oaks, CA: Sage.

Becenti, F. (1995). Leadership profiles of tribal college presidents. Dissertation Abstracts International, 56 (06), 2051A. (UMI No. 9535306)

Bechtle, M. (1993). Leadership style and stress among bible college presidents. Dissertation Abstracts International, 54 (04), 1159A. (UMI No. 9320574)

Becker, N. (1999). Implementing technology in higher education: The leadership role and perspectives of the chief information officer. Dissertation Abstracts International, 60 (07), 2395A. (UMI No. 9939460 )

Becker, W., \& Lewis, D. (1994). The economics of American higher education. The Journal of higher education 65 (1) 116.

Benezet, L.T., Katz, J., \& Magnusson, F.W. (1981). Style and substance: Leadership and the college presidency. Washington, D.C.: American Council on Education.

Bennis, W. (1989). Why leaders can't lead: The unconscious conspiracy continues. San Francisco: Jossey-Bass.

Bennis, W. (1991). Learning some basic truisms about leadership. National Forum, 71, 12-16.

Bennis, W. (1997). Managing people is like herding cats. Provo, UT: Publishers Press.

Bennis, W., \& Nanus, B. (1985). Leaders. New York: Harper \& Row.

Bensimon, E. (1989). The meaning of good presidential leadership: A frame analysis. In M. Peterson (Eds.), ASHE Reader of Organization and Governance in Higher Education (pp. 421-431). Lexington, MA: Ginn. 
Bensimon, E., Neumann, A., \& Birnbaum, R. (1989). Making sense of administrative leadership: The 'L' word in higher education. ASHE-ERIC Higher Education Report No. 1. Washington, D.C.: School of Education and Human Development, The George Washington University.

Bethel, C. (1998). A study of the relationship between presidential leadership orientation and organizational effectiveness in bible colleges. Dissertation Abstracts International, 60 (06), 1838A. (UMI No. 9926656)

Blake, R., \& Mouton, J. (1976). An overview of the grid. In W. Lassey \& R. Fernandez (Eds.), Leadership and social change (2 ${ }^{\text {nd }}$ ed., pp. 197-212). La Jolla, CA: University Associates (Reprinted from Training and Development Journal, 19(5), 1975).

Blake, R., \& Mouton, J. (1985). The managerial grid III: A new look at the classic that has boosted productivity and profits for thousands of corporations worldwide. Houston, TX: Gulf.

Bolman, L. (2003, July 22). Using leadership orientations. Section IV: Reliability of leadership orientation scales. Retrieved from http://www.bsbpa.umkc.edu/classes/bolman/new page_1.htm

Bolman, L., \& Deal, T. (1984). Modern approaches to understanding and managing organizations. San Francisco: Jossey-Bass.

Bolman, L., \& Deal, T. (1990). Leadership Orientations (Self). Brookline, MA: Leadership Frameworks.

Bolman, L., \& Deal, T. (1991). Images of leadership. Occasional Paper No. 7. The National Center for Educational Leadership. (ERIC Document Reproduction Service No. ED 332 345) 
Bolman, L., \& Deal, T. (1997). Reframing organizations: Artistry, choice, and leadership. ( $2^{\text {nd }}$ ed.). San Francisco: Jossey-Bass.

Borden, M. (2000). Leadership orientations of area campus administrators in Florida's state university and community college systems: A frame analysis. (Doctoral dissertation, University of Central Florida, 2000). Dissertation Abstracts International, 61, 3913.

Botstein, L. (1985). Leadership: Golden rules of practice. In J. Green \& A. Levine (Eds.), Opportunity in adversity: How colleges can succeed in hard times. (pp.105-125). San Francisco: Jossey-Bass.

Bowles, T. (1999). Socialization factors and African-American women college presidents. Dissertation Abstracts International, 60 (02), 354A. (UMI No. 9920820)

Bowyer-Johnson, P. (2001). The role of mentoring in the career paths of women deans and vice presidents in four-year public and private institutions of higher education. Dissertation Abstracts International, 62 (10), 3309A. (UMI No. 3031153)

Boyd, D. (2002). State spending for higher education in the coming decade. Boulder, Colorado:. National Center for Higher Education Management Systems

Bruning, J., \& Kintz, B. (1997). Computational handbook of statistics ( $4^{\text {th }}$ ed.). New York: Longman.

Bryman, A. (1996). Leadership in organization. In S. Clegg, C. Hardy, \& W. Nord (Eds.), Handbook for organizational studies (pp. 276-292). London: Sage.

Buddemeier, S. (1998). Female community college presidents: career paths, experiences, and perceptions of the presidency. Dissertation Abstracts International, 59 (03), 744A. (UMI No. 9825979)

Burns, J. (1978). Leadership. New York: Harper \& Row. 
Cantu, D. (1997). The leadership frames of academic deans randomly selected and nominated as exceptionally effective at public colleges and universities. Dissertation Abstracts International, 58 (03), 657A. (UMI No. 9724134)

Carnegie Foundation (2001). Carnegie classification of institutions of higher education, 2000 edition. Menlo Park, CA.

Cartwright, D., \& Zander, A. (Eds.). (1968). Group dynamics: Research and theory (3rd ed.). New York: Harper and Row.

Castro, J. (1998). Presidential optimism and leadership. Dissertation Abstracts International, 59 (08), 2879A. (UMI No. 9901471)

Chaffee, E., Whetton, D., \& Cameron, K. (1983). Case studies in college strategy. Boulder, CO: National Center for Higher Education Management Systems

Chemers, M., \& Ayman, R. (1993). Directions for leadership research. In M. Chemers and R. Ayman (Eds.), Leadership theory and research: Perspectives and directions. San Diego: Academic Press.

Chliwniak, L. (1996). Leadership in higher education: Influences on perceptions of women and men leaders. Dissertation Abstracts International, 57 (04), 1513A. (UMI No. 9626484)

Clark, B. (1998). Creating entrepreneurial universities: Organizational pathways of transformation. Oxford, UK: Pergamon Press.

Cobelli, J. (1989). Administrative decision-making styles in higher education. Dissertation Abstracts International, 50 (05), 1226A. (UMI No. 8918440 )

Cohen, M., \& March, J. (1974). Leadership and Ambiguity. New York: McGraw-Hill. Coleman, A. (1987). A study of leadership styles and perceptions of authority of presidents at the colleges of the city university of New York. Dissertation Abstracts International, 48 
(09), 2251A. (UMI No. 8725260)

Corrigan, M. (2002). The American college president, 2002 Edition.

Washington, D.C.: American Council on Education

Corrigan, R. (2002). Presidential leadership. Liberal Education, 88(4) 6-14

Cote, A. (1999). Leadership orientation frames of Florida elementary principals in relationship to school context and principal characteristics. Dissertation Abstracts International, 60 (12), 4257A. (UMI No. 9956561)

Cowen, S. (1990). A study of relationships between perceived leadership behaviors of presidents at public four-year institutions of higher education in the United States and the changes in fte enrollment, perceptions of effectiveness, subordinate satisfaction, and other factors of the presidency. Dissertation Abstracts International, 53 (01), 78A. (UMI No. 9121947)

Cowley, W., \& Williams, D. (1980). Presidents, professors and trustees: The evolution of American academic governance. San Francisco: Jossey-Bass.

Darby, S. (1996). The role of mentoring in the career development of women community college administrative leaders. Dissertation Abstracts International, 58 (01), 38A. (UMI No. 9719532)

Davis, R. (1984). The influences of schooling, job experience, information about job openings, mentoring, geographic mobility, and discrimination on the selection of college and university presidents. Dissertation Abstracts International, 45, 04A. (UMI No: 8414966)

Deal, T., \& Kennedy, A. (1982). Corporate cultures: The rites and rituals of corporate life. Reading, MA: Addison-Wesley. 
Demerath, N., Stephens, R. \& Taylor R. (1967). Power, presidents, and professors. New York: Basic Books.

DePree, M. (1989). Leadership is an art. New York: Dell.

DeVeaux, D. (1999). The perception of race and gender on the leadership of four African American female community college presidents. Dissertation Abstracts International, 61 (05), 1722A. (UMI No. 9974761)

Dill, D., \& Fullagar, P. (1987). Leadership and administrative style. In M. Peterson \& L. Mets (Eds.), Key resources on higher education governance, management, and leadership (pp. 390-411). San Francisco: Jossey-Bass.

Dyson, D. (1988). Presidential priorities: A study of personal performance time priorities among presidents of southern colleges and universities named among America's best institutions. Dissertation Abstracts International, 49 (08), 2038A. (UMI No. 8820620)

Echols Tobe, D. (1999). The development of cognitive leadership frames among African American female college presidents. Dissertation Abstracts International, 60 (07), 2300A. (UMI No. 9939485)

Ehrenberg, R. (1997). The American university: National treasure or endangered species? Ithaca, NY: Cornell University Press.

Evelyn, J. (2001). Community colleges face a crisis of leadership. Chronicle of Higher Education, 47, 36-37.

Everley, M. (1993). Presidential change: Interim administrations in higher education. Dissertation Abstracts International, 54 (10), 3681A. (UMI No. 9409253)

Farkas, J. (1996). A descriptive study of the attributes of women presidents of selective, 
independent baccalaureate colleges. Dissertation Abstracts International, 58 (02), 348A. (UMI No. 9722205)

Fayol, H. (1996). General principles of management. In J. Shafritz \& J. Ott, (Eds.), Classics of organizational theory (4 ${ }^{\text {th }}$ ed., pp. 52-65). Belmont, CA: Wadsworth (Original work published in 1916)

Ferrari, M. (1970). Profiles of American college president. Michigan State University.

Fisher, J. (1984). Power of the presidency. American Council on Education, New York: Macmillan.

Fisher, J., \& Koch, J. (1996). Presidential leadership: Making a difference. Phoenix, AZ: American Council on Education and Oryx Press Series on Higher Education.

Fisher, J., Tack, M., \& Wheeler, K. (1988). The effective college president. New York: American Council on Education \& Macmillan.

Flak, T. (1998). An inquiry into the leadership orientations of selected women school superintendents. Dissertation Abstracts International, 60 (02), 293A. (UMI No. 9920823)

Fraenkel, J. R., \& Wallen, N. (2000). How to design and evaluate research in Education (5th ed.). New York: McGraw-Hill.

Freeman, O. (1993). Presidential profiles in higher education: Perspectives from African American women. Dissertation Abstracts International, 54 (06), 2066A. (UMI No. 9332267)

French, J., Raven, B. (1968). Leadership: Need models of power and influence. In D. Cartwright \& A. Zander (Eds.), Group dynamics: Research and theory (3rd ed., pp. 607-623). New York: Harper and Row. 
French, J. \& Raven, B. (1996). The bases of social power. In J. M. Shafritz \& J. S. Ott (Eds.), Classics of organizational theory ( $4^{\text {th }}$ ed., pp. 375-384). Belmont, CA: Wadsworth. (Original work published 1959)

Fujita, E. (1990). What is a good college president? How leaders are judged by constituents Dissertation Abstracts International, 51 (09), 2993A. (UMI No.9103961)

Fullagar, P. (1989). Presidential succession and successor-type in U. S. colleges and Universities. Dissertation Abstracts International, 51 (06) 1920A. (UMI No. 9032960)

Gamble, M. (2003). "Living logos": Framing the discourse of the university presidency. Dissertation Abstracts International, 64, 06A. (UMI No. 3094585)

Gardner, J. (1990). On Leadership. New York: The Free Press.

Gatteau, R. (2000). Breaking barriers in higher education: An exploration of female presidential leadership at six selective institutions. Dissertation Abstracts International, 61 (06), 2209A. (UMI No. 9975349)

Gilley, J., Fulmer, K., \& Reithlingshoefer, S. (1986). Searching for academic excellence: Twenty colleges and universities on the move and their leaders. New York: Macmillan.

Goldman, P., \& Smith, N. (1991). Filling the frames: Using Bolman and Deal to analyze an educational innovation. Revision of a paper presented at the annual Meeting of the Canadian Society for the Study of Education (Kingston, Ontario, Canada June 2-5, 1991 (15 pages).

Gorena, M. (1994). Hispanic women in higher education administration: Factors that positively influence or hinder advancement to leadership positions. Dissertation Abstracts International, 55 (01), 4664A. (UMI No. 9416460)

Graham, T. (1997). Career strategies, career mentoring, and career destinies: A comparative 
analysis of career paths pursued by African American and white community college presidents. Dissertation Abstracts International, 58 (03), 709A. (UMI No. 9726065)

Greer, C. (1981). The perceptions and status of the black administrative woman in selected two-year and four-year coeducational colleges and universities Dissertation Abstracts International, 42 (06), 2525A. (UMI No. 8125771)

Green, J. \& Levine, A. (1985). Opportunity in adversity : How colleges can succeed in hard times. San Francisco: Jossey-Bass.

Gubanich, R. (1991). The relationship between leadership style and burnout among college and university presidents. Dissertation Abstracts International, 53 (01),79A. (UMI No. 9212681)

Guill, J. (1991). Conflict management style preferences of community college presidents. Dissertation Abstracts International, 52 (12), 4163A. (UMI No. 9208898)

Hackman, M., \& Johnson, C. (2000). Leadership: A communication perspective. Prospect Heights, IL: Waveland Press.

Hahn, R. (1995). Getting serious about presidential leadership. Change 27 (5), 12-20.

Halpin, A. (1957). Leader behavior description questionnaire; Ideal leader behavior. Columbus, OH: Ohio State University.

Harlow, J. (1994). Educational leadership: A frame analysis. (Doctoral dissertation, Seattle University, 1994).Dissertation Abstracts International, 55, 2227.

Heimovics, R., Herman, R., \& Coughlin, C. (1993). Executive leadership and resource dependence in nonprofit organizations: A frame analysis. Public Administration Review, 53, 419-427.

Hensley, R. (1998). A case study of presidential leadership in selected Montana higher 
education institutions. Dissertation Abstracts International, 59 (04), 1090A. (UMI No. 9830107)

Hersey, P., \& Blanchard, K. (1982). Management of organizational behavior: Utilizing human resources. Englewood Cliff, NJ: Prentice Hall.

Hertzberg, F. (1996). One more time: How do you motivate employees? In J. Ott, (Ed.), Classic readings in organizational behavior (2nd ed., pp. 76-85). Belmont, CA: Wadsworth. (Original work published 1968)

Hickerson, P. (1986). The current status of women and blacks in Tennessee higher education administration. Dissertation Abstracts International, 49 (07), 1641A. (UMI No. 8809162)

Holder, J. (1993). Leadership effectiveness of college and university presidents: A study of the application of humanistic leadership and machiavellian management theories. Dissertation Abstracts International, 55 (04), 878A. (UMI No. 9416829)

Hovey, H. (1999). State spending for higher education in the next decade: The battle to sustain current support. National Center Report \# 99-3. The National Center for Public Policy and Education. Washington, D.C.

Hoy, W., \& Miskel, C. (1996). Education Administration: Theory, research, \& practice (5 ${ }^{\text {th }}$ ed.) New York: McGraw Hill.

Hubbard, S. (1993). Factors facilitating administrative placement of females in higher education Administration. Dissertation Abstracts International, 54 (02), 398A. (UMI No. 9316249)

Hurtubise, M. (1988). An analysis of presidential attitudes toward and participation in fund raising at select, small, independent, liberal arts colleges and universities. Dissertation Abstracts International, 50 (05), 1157A. (UMI No. 8918233) 
Jablonski, M. (1992). Leadership styles of women college presidents. Dissertation Abstracts International, 53 (03), 676A. (UMI No. 9221576)

Janney, S. (1994). The college president and fund raising effectiveness. Dissertation Abstracts International, 55 (12), 3700A. (UMI No 9512833)

Jeffcoat, H. (1994). University presidents, as autobiographers. Dissertation Abstracts International, 55 (08), 2307A. (UMI No. 9501956)

Jones, S. (1995). The glass ceiling and African-American administrators in higher education Dissertation Abstracts International, 56 (08), 3327A. (UMI No. 9537083)

Juhan, G. (1993). An assessment of role ambiguity, role conflict, role frustration, and job satisfaction of presidents at selected private four-year colleges in the southeastern United States. Dissertation Abstracts International, 54 (09), 3281A. (UMI No. 9400308)

Kaiser, H., \& Davis, J. (1996). A foundation to uphold: A study of facilities conditions at U. S. Colleges and Universities. Washington, D. C.: NACUBO.

Kane, J. (1997). Differences in the career lines of black and white women college presidents. Dissertation Abstracts International, 58 (04), 1163A. (UMI No. 9728786)

Kane, S. (2001). Mid-level student affairs administrators' organizational "frame" orientations and perceptions of their effectiveness by senior student affairs officers. Dissertation Abstracts International, 62 (12), 4087A. (UMI No. 3035847)

Kanter, R. (1984). The change masters: Innovation and entrepreneurship in the American corporation. New York: Simon and Schuster.

Karol, N., \& Ginsburg, S. (1980). Managing the higher education enterprise. New York: John Wiley \& Sons.

Katz, R. (1974). Skills of an effective administrator. Harvard Business Review,52, 90-102. 
Kauffman, J. (1980). At the pleasure of the board. Washington, D.C.: American Council on Education.

Kelts, K. (1998). How women leaders define power: Case studies of three women college presidents in New England. Dissertation Abstracts International, 59 (10), 111A. (UMI No. 9910292)

Keohane, N. (2003). When should a college president use the bully pulpit? Chronicle of Higher Education, 49, 20.

Kerlinger, F. (1986) Foundations of behavior research ( $3^{\text {rd }}$ ed.) New York: CBS College.

Kerr, C. (1984). Presidents make a difference: Strengthening leadership in colleges and universities. A report of the commission on strengthening presidential leadership. Washington, D.C.: Association of Governing Boards of University and Colleges.

Kerr, C. (1994). Troubled times for American higher education: The 1990s and beyond. Albany, NY: State University of New York Press.

Kerr, C., \& Gade, M. (1986). The many lies of academic presidents: Time place and character. Washington, D.C.: The Association of Governing Boards of University and Colleges.

Kerr, C., \& Gade, M. (1987). The contemporary college president. American Scholar, 56, 2944.

Kilmann, R., Saxton, M., Serpa, R., et al. (1985). Gaining control of the corporate culture. San Francisco: Jossey-Bass.

Kisling, F. (1986). A descriptive comparison of women presidents of two-year and 
four year colleges and universities Dissertation Abstracts International, 48 (01), 59A. UMI No. 8709543)

Komives, S., Lucas, N., \& McMahon, T. (1998). Exploring leadership: For college students who want to make a difference. San Francisco: Jossey-Bass.

Krampien, P. (1995). Academic deans at small colleges: Characteristics, challenges, functions, and professional support systems. Dissertation Abstracts International, 56 (09), 3395A. (UMI No. 9600852)

Krumm, B. (1997). Leadership roles of American Indian women tribal college Presidents. Dissertation Abstracts International, 58 (06), 2006A. (UMI No. 9736939)

Kumle, J., \& Kelly, N. (2000, April). Leadership vs. management. Supervision 61, 8-11.

Lagakis, V. (2001). Female chief executive officers: A national study of the profile and career progression of female presidents/chancellors in public master's colleges and universities I and II in the United States. Dissertation Abstracts International, 62 (09), 2989A. (UMI No: 3027037)

Levine, A. (1998). Succeeding as a leader: Failing as a president. Change 30, 42-46.

Levine, A., \& Cureton, J. (1998). When hope and fear collide. San Francisco: Jossey-Bass.

Levine, M. (2000). The importance of leadership: An investigation of presidential style at fifty national universities. Dissertation Abstracts International, 61 (10), 3841A. (UMI No. 9992651)

Lockard, N. (2000). A study to examine the similarities and differences in leadership style between two selected groups of university presidents. Dissertation Abstracts International, 61 (10), 3842A. (UMI No. 9988864)

Long, R. (1980). Career patterns of top-level administrators of selected four year evangelical 
liberal arts and bible colleges. Dissertation Abstracts International, 41 (04), 1430A.

(UMI No. 8020336)

Lovett, C. (2002). The dumbing down of college presidents. Chronicle of Higher Education. 48, 20.

Macera, M. (1989). Critical presidential management skills: A comparative study of chief executive officers within the business and academic communities. Dissertation Abstracts International, 50 (09), 2733A. (UMI No. 9003815)

Magnuson, M. (2002). The relationship between career paths, institutional types, demographics and the operational frameworks of college and university presidents. Dissertation Abstracts International, 64, 04A. (UMI No. 3088049)

Mancini, D. (1993). Career paths to the academic presidency: a comparison study of gender differences. Dissertation Abstracts International, 54 (12), 4610A. (UMI No. 9414054)

Marbury, R. (1992). African-American senior administrators of colleges and universities in American higher education: Identification of characteristics in their career progression. Dissertation Abstracts International, 53 (04), 1010A. (UMI No: 9224998)

Markus, H., \& Zajonc, R. (1985). The cognitive perspective in social psychology. In G. Lindzey \& E. Aronson (Eds.), Handbook of social psychology (3 ${ }^{\text {rd }}$ ed., pp. 137-230). New York: Random House.

Maslow, A. (1996). The theory of human motivation. In J. M. Shafritz \& J. S. Ott (Eds.), Classics of organizational theory ( $4^{\text {th }}$ ed., pp. 163-175). Belmont, CA: Wadsworth. (Original work published 1943)

Mata, D. (1997). A profile of Latino community college presidents: A multi-method study of leadership development and functioning. Dissertation Abstracts International, 58 (10), 
3817A. (UMI No. 9811249)

Mathern, D. (1998). Leadership strategies of American university presidents: a leadership model analysis Dissertation Abstracts International, 59 (12), 4325A. (UMI No. 9913591)

McGregor, D. (1996). The human side of enterprise. In J.M. Shafritz \& J.S. Ott (Eds.), Classics of organizational theory ( $4^{\text {th }}$ ed., pp.176-185). Belmont, CA: Wadsworth. (Original work published 1957)

McHugh, C. (1991). Presidential leadership: Criteria for excellence in the leadership of American colleges and universities. Dissertation Abstracts International, 53 (02), 421A. (UMI No. 9220571)

Messer, J. (2002). Elementary principal leadership orientations and selected professional and school variables. Dissertation Abstracts International, 63 (02), 450A. (UMI No. 3042963)

Minor, J. (2001). Making sense of success: Leadership attributes and practices of successful university presidents. Dissertation Abstracts International, 62 (07), 2360A. (UMI No. 3020847)

Mintzberg, H. (1983). Power in and around organizations. Englewood Cliffs. NJ: Prentice-Hall. Mintzberg, H. (1996). The power game and the players. In J. Shafritz \& J. Ott (Eds.), Classics of organizational theory ( $4^{\text {th }}$ ed., pp. 412-419). Belmont, CA: Wadsworth. (Original work published 1983)

Mosser, N. (2000). A study of the relationship between the perceived leadership style of nursing chairpersons and the organizational climate in baccalaureate nursing programs. (Doctoral dissertation, West Virginia University, 2000). Dissertation Abstracts International, 62, 43A. 
Murphy, M. (1997). The advancement president and the academy: Profiles in institutional leadership. Phoenix, AZ: Oryx Press.

National Center for Education Statistics. (2003) Washington D. C.

Nelson, S. (1996). A study of the moral voice of the college president. Dissertation Abstracts International, 57 (03), 1048A. (UMI No. 9623488)

Northouse, P. (2001). Leadership: Theory and practice. Thousand Oaks, CA: Sage.

Ott, J. (Ed.). (1996). Classic readings in organizational behavior ( $2^{\text {nd }}$ ed.) Belmont, CA: Wadsworth.

Overland, W. (1996). College presidents' achieving styles and their perceptions of gender role identity. Dissertation Abstracts International, 58 (03), 771A. (UMI No. 9726237)

Owens, R. (1995). Organizational behavior in education ( $5^{\text {th }}$ ed.) Needham Heights, MA: Allyn and Bacon.

Pearson, G., \& Young, A. (Eds.). (2002). Technically speaking: Why all Americans need to know more about technology. Washington, D.C.: National Academy Press.

Peterson, M., Chaffee, E., \& White, T. (1991). Organization and Governance in higher education ( $4^{\text {th }}$ ed.), Needham Heights, MA: Simon \& Schuster.

Peterson, M., \& Mets, L. (1987). Key resources on higher education governance, management and leadership: A guide to the literature. San Francisco: Jossey-Bass.

Pfeffer, J. (1981). Power in organization. Marshfield, MA: Pitman.

Pierce, M. (1992). Patterns of advancement in public higher education by South Carolina women administrators: Implications for leadership. Dissertation Abstracts International, 53 (11), 3764A. (UMI No. 9307974 )

Price, W. (2000). An analysis of the elements of accession of African American 
women presidents of historically White four-year, state-supported colleges and universities. Dissertation Abstracts International, 62 (06), 4633A. (UMI No. 9997205)

Pullias, E., \& Wilburn, L. (1984). Principles and values for college and university administration: Toward the improvement of the learning environment. New York : Philosophical Library

Redman, M. (1991). A comparative study of the leadership orientation frames of administrators in private Japanese and American institutions of higher education. Dissertation Abstracts International, 52 (07), 2431A. (UMI No. 9201938)

Reece, A. (1997). Perceptions of barriers to women in the advancement to ceo positions in higher education in the southeast. Dissertation Abstracts International, 58 (06), 2013A. (UMI No. 9735744)

Reed-Taylor, J. (1998). Career paths, mobility patterns, and experiences of two-year college women presidents of color. Dissertation Abstracts International, 59 (10), 3724A. (UMI No. 9909721)

Rhodes, F. (1998). The art of the presidency. Presidency 1, 12-18.

Rivers, P. (1996). A frame analysis of principals' leadership orientations. Dissertation Abstracts International, 57 (07), 2785A. (UMI No. 9637016)

Rittof, P. (2001). Presidential type, lay or religious, and the distinctive Catholic identity of small Catholic colleges and universities in the United States: Does it make a difference? Dissertation Abstracts International, 62 (06), 2050A. (UMI No. 3018532)

Robinson, D. (1996). Black college and university presidents at predominantly white four-year institutions: Factors which hinder and facilitate advancement. Dissertation Abstracts International, 57 (12), 5079A. (UMI No. 9717065) 
Robinson, F. (1996). Preparing African-American women for the community college presidency: implications for adult continuing education. Dissertation Abstracts International, 57 (07), 2824A. (UMI No. 9639935)

Roehlisberger, F. J. (1996). The Hawthorne experiment. In J. S. Ott, (Ed.), Classic readings in organizational behavior ( $2^{\text {nd }}$ ed., pp. 35-44). Belmont, CA: Wadsworth (Original work published 1941)

Ross, M., \& Green, M. (2000). The American college president, 2000 Edition. Washington, D.C.: American Council on Education.

Rosen, A., Billings, R. Robber, S. \& Turney, C. (1976). The emergence and allocation of leadership resources over time in a technical organization, Academy of Management Journal (19), 165-183.

Rouse, L. (1998). A comparison of African-American and Anglo-European community college leaders. Dissertation Abstracts International, 59 (06), 1883A. (UMI No. 9837016)

Russell, C. (2000). Community college academic deans: Leadership frames and stress Dissertation Abstracts International, 61 (10), 3866A. (UMI No. 9990484)

Salimbene, A. (1982). Pathways to the presidency: An examination of the careers of current college and university chief executives. Dissertation Abstracts International, 43 (10), 3237A. (UMI No. 8305694)

Sawyer, C. (1996). The participative leader: a case study of a woman college. Dissertation Abstracts International, 57 (07), 2904A. (UMI No 638772)

Schein, E. (1985). Organizational culture and leadership. San Francisco: Jossey-Bass.

Schein, E. (1996). The learning leader as culture manager. In J. Ott, (Ed.), Classic readings 
in organizational behavior ( $2^{\text {nd }}$ ed., pp. 35-44). Belmont, CA: Wadsworth (Original work published 1992)

Selingo, J. (2000, November 17). Facing new missions and rivals, state colleges seek a makeover: Can the undistinguished middle child of public higher education find a fresh identity. Chronicle of Higher Education. A 40-45.

Senge, P. (1990). The fifth discipline: The art and practice of the learning organization. NewYork: Doubleday.

Sergiovanni, T., Burlingame, M., Coombs, F., \& Thruston, P. (1992). Educational governance and administration ( $3^{\text {rd }}$ ed.) Boston, MA: Allyn and Bacon.

Shafritz, J., \& Ott, J. (Eds.). (1996). Classics of organizational theory (4 ${ }^{\text {th }}$ ed.) Belmont, CA: Wadsworth.

Shaw, K. (1999). The successful president: “Buzzwords” on leadership. Phoenix, AZ: Oryx.

Shawver, M. (1985). Career pathways of academic presidents with formal preparation in higher education/administration. Dissertation Abstracts International, 47 (02), 378A. (UMI No. 8608446)

Siegel, M. (2001). Presidential architects, cultural blueprints: Learning and sense making in the first year of the college presidency. Dissertation Abstracts International, 62 (08), 2698A. (UMI No. 3024302)

Small, T. (2002). A study of the relationship between the perceived leadership style of nursing chairpersons and the organizational effectiveness of baccalaureate nursing programs. (Doctoral dissertation, West Virginia University, 2002). Dissertation Abstracts International, 63, 2077A. 
Smith, B. (2001). An occupational performance profile of college presidents. Dissertation Abstracts International, 62 (03), 871A. (UMI No. 3010653)

Smith, M. (1996). The role of the president at small religious colleges. Dissertation Abstracts International, 57 (03), 962A. (UMI No: 9622584)

Spanier, G. (2000, June/July). Five challenges facing American Higher Education. Executive Speeches 14, 19-25.

Spivey, L. (1983). An analysis of the perceptions of leadership styles and behavior of college/university presidents by deans at selected institutions of higher education in the united states Dissertation Abstracts International, 44 (11), 3239A. (UMI No. $8401458)$

Sterneckert, R. (1980). Profile analysis involving social/personal characteristics and career patterns representative of college and university chief executive officers of public and private four-year institutions. Dissertation Abstracts International, 41 (06), 2473A. (UMI No. 8025568$)$

Stodgill, R. (1948). Personal factors associated with leadership: A survey of the literature. Journal of Psychology(25), 35-71.

Stodgill, R. (1981). Traits of leadership: A follow-up to 1970. In B. M. F(Ed.), Stodgill's handbook of leadership (pp. 73-82). New York, NY: Free Press.

Stokes, H. (1959). The American college president. New York: Harper.

Suzuki, Y. (1994). A comparative study of the leadership orientation frames of California Asian and other public school principals. Dissertation Abstracts International, 55 (07), 1780A. (UMI No. 9426165)

Taylor, F. (1996). The principles of scientific management. In J. M. Shafritz \& J. S. Ott 
(Eds.), Classics of organizational theory (4 $4^{\text {th }}$ ed., pp. 66-79). Belmont, CA: Wadsworth. (Original work published 1916)

Tierney, W. (1989). Symbolism and presidential perceptions of leadership. Review of Higher Education, 12(2), 153-166.

Tierney, W. (1991). Advancing democracy. A critical interpretation of leadership. Peabody Journal of Education, 66(3), 157-173.

Tingey, K. (1997). College and university presidential leadership: Framed by leadership orientation and institution type. Dissertation Abstracts International, 57 (12), 5293A. (UMI No. 9717721)

Travis, A. (1996). Leadership styles of senior student affairs officers: A comparison by race and gender. Dissertation Abstracts International, 57 (11), 4619A. (UMI No. 9711725)

Trudeau, G. (2001). Interim presidents in higher education: An analysis of factors influencing the interim presidential leadership experience in Minnesota and Wisconsin. Dissertation Abstracts International, 62 (01), 47A. (UMI No. 3002787)

Truschel, J. (1997). A comparative study of perceived leadership styles of the Pennsylvania state system of higher education university presidents. Dissertation Abstracts International, 58 (03), 689A. (UMI No: 9724291)

Turley, C. (2002). Radiation therapy program directors: A frames analysis of leadership in higher education. Dissertation Abstracts International, 63 (03), 1246B. (UMI No. 3045492)

Ulmer, M. (2002). Principals' leadership practices in the context of state assessments. Dissertation Abstracts International, 63 (04), 1221A. (UMI No. 3050209)

Van Dusen, G. (2000). Digital dilemma: Issues of access, cost, and quality in media-enhanced 
and distance education. San Francisco: Jossey-Bass.

Vaughan, G. (1989). Leadership in transition: the community college presidency. New York: American Council on Education and Macmillan.

Waters, L. (1993). Presidential leadership in historically black colleges and universities. Dissertation Abstracts International, 54 (10), 3684A. (UMI No. 9407705)

Weber, M. (1996). Bureaucracy. In J. S. Ott, (Ed.), Classics of organizational theory (4 ${ }^{\text {th }}$ ed., pp. 80-85). Belmont, CA: Wadsworth (Original work published 1946)

Weathersby, G. (1999, March). Leadership vs. management. Management Review, 88 5.

Weick, K. (1979). The social psychology of organizing. Reading, MA: Addison-Wesley.

Weick, K. (1983). Educational organizations as loosely coupled systems. In J. V. Baldridge \& T. Deal (Eds.), The dynamics of organizational change in education (pp.126-147). Berkley, CA: McCutchan.

Welch, M. (2002). Leadership frames of female presidents of American research universities. Dissertation Abstracts International, 63 (02), 09A. (UMI No. 3065731)

Wessel, R. (1991). Profiles and career patterns of private, four-year college and university presidents. Dissertation Abstracts International, 53 (02), 423A. (UMI No. 9219811)

Wheeler, K., \& Tack, M. (1989) Male and female college presidents: Leadership behaviors and attitudes. Paper presented at the Annual Meeting of the American Research Association (San Francisco, CA, March 27-31, 1989). ERIC \# ED309687

Williams, R. (1981). Career patterns of women in educational fund raising administration in American colleges and universities. Dissertation Abstracts International, 42 (01), 110A. (UMI No. 8114730)

Wilson, M. (2002). Leadership characteristics needed by presidents of historically 
black colleges and universities as perceived by academic vice presidents. Dissertation Abstracts International, 63 (03), 837A. (UMI No. 3045495)

Wise, J. (1984). Environmental status and leadership behavior of liberal arts college

Presidents. Dissertation Abstracts International, 45 (02), 433A. (UMI No. 8410600)

Wolf, R. (1998). Campus safety directors: A leadership frame analysis. Dissertation Abstracts International, 59 (11), 4082A. (UMI No. 9910810)

Wright-Tatum, P. (1999). Job satisfaction of academic administrators at historically black colleges and universities Dissertation Abstracts International, 60 (09), 3292A. (UMI No. $9946315)$

Yukl, G. (1994). Leadership in organizations ( $3^{\text {rd }}$ ed). Englewood Cliffs, NJ: Prentice Hall. Zhang, C. (1993). Risks of presidential leadership in small private colleges: Challenges in shaping institutional vision. Dissertation Abstracts International, 54 (10), 3685A. (UMI No. 9409251) 


\section{Appendix A}

Permission to use survey instrument 
Dear Mr. Monahan:

I am happy to give you permission to use the Leadership Orientations survey instrument in your doctoral research subject to our standard conditions: that you agree to provide us a copy of any publications or reports that you produce that are based in whole or in part on data collected using our instrument, and that you further agree to make available to us, if we request it, a copy of your data file.

Best wishes in your research.

Lee G. Bolman

Marion Bloch/Missouri Chair in Leadership

Bloch School of Business and Public Administration

University of Missouri-Kansas City

5100 Rockhill Road

Kansas City, MO 64110

Tel: (816) 235-5407

Fax: (816) 235-6529

Email: bolmanl@umkc.edu

Original Message-----

From: Mike Monahan [mailto:MLMonahan@mail.wvu.edu]

Sent: Monday, March 31, 2003 7:53 AM

To: bolmanl@umkc.edu

Subject: Survey request for Dissertation

Hello Dr. Bolman,

My name is Michael Monahan and I am a doctoral candidate at West Virginia University. My dissertation is on the leadership styles of Masters I presidents.

I request permission to use your LEADERSHIP ORIENTATIONS (SELF) survey instrument and permission to add approximately 10 demographic questions.

Thank you in advance for your time and consideration.

Sincerely,

Michael Monahan 
Appendix B

Survey Instrument 


\section{Survey Instrument}

\section{LEADERSHIP ORIENTATIONS (SELF)}

This questionnaire asks you to describe your leadership and management style.

\section{BEHAVIORS}

You are asked to indicate how often each of the items below is true of you

So, you would answer (1) for an item that is never true of you, (2) for one that is occasionally true,

(3) for one that is sometimes true of you, and so on.

Never Occasionally Sometimes $\underline{\text { Often Always }}$

Please use the following scale in answering each item

1. Think very clearly and logically

2. Show high levels of support and concern for others

3. Have exceptional ability to mobilize people and resources to get things done

4. Inspire others to do their best

5. Strongly emphasize careful planning and clear time lines

6. Build trust through open and collaborative relationships.

7. Am a very skillful and shrewd negotiator

8. Am highly charismatic

9. Approach problems through logical analysis and careful thinking

10. Show high sensitivity and concern for others' needs and feelings

11. Am unusually persuasive and influential

12. Am able to be an inspiration to others

13. Develop and implement clear, logical policies and procedures

14. Foster high levels of participation and involvement in decisions

15. Anticipate and deal adroitly with organizational conflict

16. Am highly imaginative and creative

17. Approach problems with facts and logic

18. Am consistently helpful and responsive to others

19. Am very effective in getting support from people with influence and power

20. Communicate a strong and challenging sense of vision and mission

21. Set specific, measurable goals and hold people accountable for results 
22. Listen well and am unusually receptive to other people's ideas and input

23. Am politically very sensitive and skillful

24. See beyond current realities to generate exciting new opportunities

25. Have extraordinary attention to detail

26. Give personal recognition for work well done

27. Develop alliances to build a strong base of support

28. Generate loyalty and enthusiasm

29. Strongly believe in clear structure and a chain of command

30. Am a highly participative manager

31. Succeed in the face of conflict and opposition

32. Serve as an influential model of organizational aspirations and values

Copyright 1990, Leadership Frameworks, 440 Boylston Street, Brookline, Massachusetts 02146. All rights reserved Used by permission of Dr. Lee Bolman 


\section{LEADERSHIP STYLES}

This section asks you to describe your leadership style. For each item, give the number (4) to the phrase that best describes you, "3" to the item that is next best, and down to " 1 " for the item that is least like you.

1. My strongest skills are:

a. Analytic skills

b. Interpersonal skills

c. Political skills

d. Ability to excite and motivate

2. The best way to describe me is:

a. Technical expert

b. Good listener

c. Skilled negotiator

d. Inspirational leader

3. What has helped me the most to be successful is my ability to:

a. Make good decisions

b. Coach and develop people

c. Build strong alliances and a power base

d. Energize and inspire others

4. What people are most likely to notice about me is my:

a. Attention to detail

b. Concern for people

c. Ability to succeed, in the face of conflict and opposition

d. Charisma

5. My most important leadership trait is:

a. Clear, logical thinking

b. Caring and support for others

c. Toughness and aggressiveness

d. Imagination and creativity

6. I am best described as:

a. An analyst

b. A humanist

c. A politician

d. A visionary 


\section{Overall Rating}

Compared to other individuals that you have know with comparable levels of Experience and responsibility, how would you rate yourself on:

\section{Overall effectiveness as a manager} 1

Bottom 20\%

\section{2}

Middle 20\%

4

5

Top $20 \%$

2.Overall effectiveness as a leader 1 2

Bottom 20\%

3
Middle $20 \%$

4

5

Top 20\% 
Section IV. Demographics

Please respond to each question by selecting the appropriate response.

1.What is the status of your presidency? Interim/Temporary Permanent

\section{What presidency is this for you?}

First presidency Second presidency Third or more presidency

\section{How long have you been a college president?} Less than 1 year

1 to 5 years

6 to 10 years

$11-15$ years

Over 15 years

\section{What was your last position?}

President at another institution

Academic VP, Dean or Chair

Student Affairs

Administration and Finance

Development

Outside of Higher Ed (please specify) Business Military Clergy

Other

\section{What is your age?}

Under 30

30 to 39

40 to 49

50 to 59

Over 60
6. What is your race?

Caucasian

African-American

Hispanic

American Indian

Asian/Pacific Islander

Other

\section{What is your highest degree earned?}

Ph. D

Ed. D

M.D.

Law

LLB

JD

Masters

Bachelors

Other (e.g. Divinity, Music)

8. What is your academic expertise of your highest degree? Fine Arts/Humanities

Social Sciences

Physical/Natural Sciences

Medicine

Law

Education

Agriculture

Religious Studies

9. What is your marital status?

Never married

Single

Married

Widow(er)

Divorced

10. What is your gender?

Female

Male

THANK YOU VERY MUCH FOR TAKING TIME TO RESPOND TO THIS SURVEY!

Please mail your completed questionnaire in the enclosed envelope by XXX $\underline{\text { YY, } 2003}$ 


\section{Appendix C}

Cover Letter

Dear President

I ask your assistance in providing information for my dissertation on the Leadership Styles of Masters I presidents. I know that you are extremely busy, but this survey should take approximately 15 minutes to complete. Very few studies have examined presidential leadership of Masters I institutions. My study can gain important insights and a better understanding and will assist me and potential Masters I presidential candidates about leadership needed to become a president.

Drs. Lee Bolman and Terrence Deal designed the Leadership Orientations (Self) instrument to determine the leadership and management style of organizational leaders. To further this research, I request your participation. Your participation in whole or in part is entirely voluntary and you do not have to respond to every question. Please be assured that your confidentiality and anonymity will be maintained as no reference to you or your institution will be made in the analysis and reporting of the data from this survey.

I would greatly appreciate your returning the completed survey to me in the enclosed envelope by XXX YY, 2003.

Again, your help is most needed and appreciated. I will gladly provide you with a summary of the findings if you so desire.

Thank you again for your assistance.

Sincerely,

Michael Monahan

Ed.D Candidate

West Virginia University 


\section{Appendix D}

Follow-up letter

Dear President

Three weeks ago you were mailed the Bolman and Deal Leadership Orientations (Self) instrument researching the leadership style of Masters I presidents. If you have already returned the survey, thank you. Please disregard this request.

I understand that your time is valuable, but your responses will add to the integrity of the study. A second copy of the survey is enclosed and should take no more than fifteen minutes to complete. Please return it to me at the above address.

Thank you again for your assistance.

Sincerely,

Michael Monahan

Ed.D Candidate

West Virginia University 


\section{Appendix E}

Institutional Characteristics

\begin{tabular}{ccccc} 
Type of Control & Public & $\begin{array}{c}\text { Private-not } \\
\text { for profit }\end{array}$ & $\begin{array}{c}\text { Private-for } \\
\text { profit }\end{array}$ & Total \\
\hline Number & 248 & 245 & 1 & 494
\end{tabular}

\begin{tabular}{crrrr} 
Enrollment & Public & Private & $\begin{array}{c}\text { Private-for } \\
\text { profit }\end{array}$ & Total \\
\hline$<2000$ & 8 & 58 & 1 & 67 \\
$2001-4000$ & 36 & 92 & & 128 \\
$4001-6000$ & 51 & 54 & & 105 \\
$6001-10000$ & 81 & 32 & & 113 \\
$>10000$ & 72 & 9 & & 81 \\
Total & 248 & 245 & 1 & 494
\end{tabular}




\section{Appendix F}

\section{Size of Institutions}

The Fall 2001 enrollment for all 494 institutions were obtained from the National Center for Education Statistics. The institutions were then categorized into 5 categories.

\begin{tabular}{lccccc} 
& Under & & & \\
Enrollment & 2,000 & $2,001-4,000$ & $4,001-6,000$ & $6,001-10,000$ & Over 10,000 \\
\hline \multirow{2}{*}{ Number } & 67 & 128 & 105 & 113 & 81
\end{tabular}




\section{Appendix G}

\section{Location Breakdown for Institutions}

The National Center for Education Statistics categorized institutions of higher education into eight geographical categories. These categories are: New England, Mid-East, Great Lakes, Plains, South-East, South-West, Rocky Mountain, and Far West.

Geographic breakdown of institutions

\begin{tabular}{|c|c|c|c|c|c|c|c|}
\hline $\begin{array}{l}\text { New } \\
\text { England }\end{array}$ & $\begin{array}{l}\text { Mid- } \\
\text { Atlantic }\end{array}$ & $\begin{array}{l}\text { Great } \\
\text { Lakes }\end{array}$ & Plains & $\begin{array}{l}\text { South } \\
\text { East }\end{array}$ & $\begin{array}{l}\text { South } \\
\text { West }\end{array}$ & $\begin{array}{l}\text { Rocky } \\
\text { Mountain }\end{array}$ & $\begin{array}{l}\text { Far } \\
\text { West }\end{array}$ \\
\hline $\mathrm{CT}$ & $\mathrm{DE}$ & IL & IA & $\mathrm{AL}$ & $\mathrm{AZ}$ & $\mathrm{CO}$ & $\mathrm{AK}$ \\
\hline $\mathrm{ME}$ & $\mathrm{DC}$ & IN & $\mathrm{KS}$ & $\mathrm{AK}$ & $\mathrm{NM}$ & ID & $\mathrm{CA}$ \\
\hline MA & $\mathrm{MD}$ & MI & $\mathrm{MN}$ & FL & OK & MT & $\mathrm{HI}$ \\
\hline $\mathrm{NH}$ & $\mathrm{NJ}$ & $\mathrm{OH}$ & $\mathrm{MO}$ & GA & TX & $\mathrm{UH}$ & NV \\
\hline RI & NY & WI & $\mathrm{NE}$ & KY & & WY & OR \\
\hline \multirow[t]{7}{*}{$\mathrm{VT}$} & PA & & ND & LA & & & WA \\
\hline & & & SD & MI & & & PR \\
\hline & & & & $\mathrm{NC}$ & & & \\
\hline & & & & $\mathrm{SC}$ & & & \\
\hline & & & & $\mathrm{TN}$ & & & \\
\hline & & & & VA & & & \\
\hline & & & & WV & & & \\
\hline
\end{tabular}




\section{Appendix $\mathrm{H}$}

\section{Community Population Categories}

Large City:

Mid Size City:

Urban Fringe of Large City:

Urban Fringe of Mid Size City:

Large Town:

Small Town:

Rural:
An area defined by the United States Department of the Census as a metropolitan statistical areas with a population greater than 250,000 .

An area defined by the United States Department of the Census as a metropolitan statistical area (MSA) with a population less than 250,000 .

Any incorporated MSA of a Mid-size City and defined as urban by the Census Bureau.

Any incorporated MSA of a Mid-size City and defined as urban by the Census Bureau.

An incorporated place with a population greater than 25,000 as defined by the Census Bureau.

An incorporated place with a population less than 25,000 and greater than 2,500 as defined by the Census Bureau.

An incorporated place with a population less than 2,500 as defined by the Census Bureau. 